
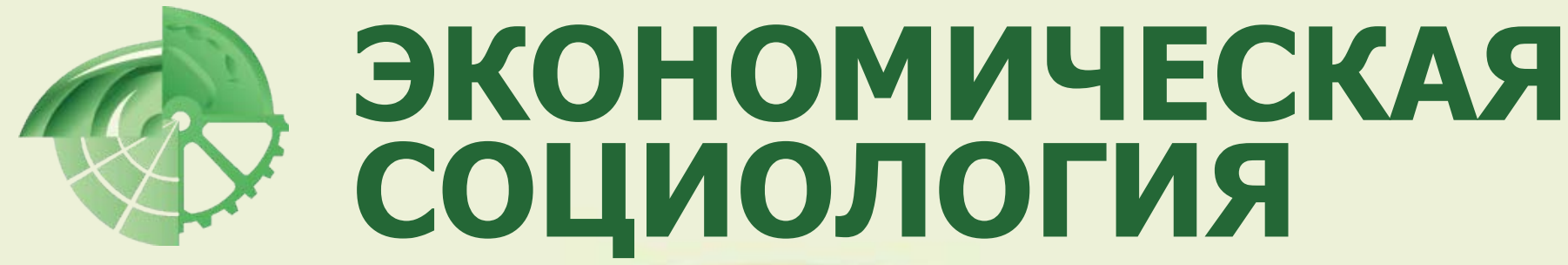

JOURNAL OF ECONOMIC SOCIOLOGY = EKONOMICHESKAYA SOTSIOLOGIYA

Читайте в номере:

Вебер М. Хозяйство и общество: очерки понимающей социологии. Общности

Мохов С. В. Управляя неопределённостью и стигмой: региональный рынок ритуальных услуг в этнографических заметках

Zhdanov V. Post-Authoritarian Devolution: The Case of the First Italian Republic 


\section{Экономическая}

социология

T. 18. № 1.

Январь 2017

Электронный журнал www.ecsoc.msses.ru www.ecsoc.hse.ru

ISSN 1726-3247

\section{Адрес редакции}

101000, Россия,

г. Москва,

ул. Мясницкая,

д. 20, комн. 406

тел.: +7 (495) 628-48-86

email: ecsoc@hse.ru

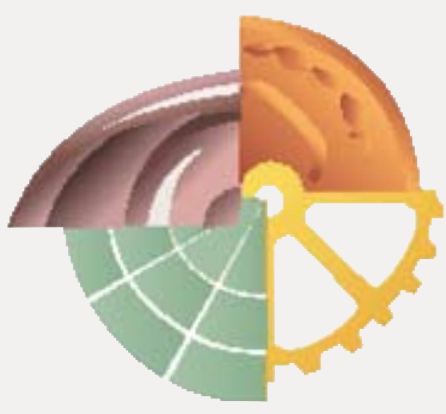

Journal of Economic Sociology Vol. 18. No 1. January 2017

Electronic journal www.ecsoc.msses.ru www.ecsoc.hse.ru

ISSN 1726-3247

\section{Contacts}

20 Myasnitskaya street, room 406

101000, Moscow,

Russian Federation phone: +7 (495) 628-48-86 email: ecsoc@hse.ru лектронный журнал «Экономическая социология» издаётся с 2000 г. Учредителями являются Национальный исследовательский университет «Высшая школа экономики» (с 2007 г.) и Вадим Валерьевич Радаев (главный редактор).

Цель журнала - утверждать международные стандарты экономико-социологических исследований в России, представлять современные работы российских и зарубежных авторов в области экономической социологии, информировать профессиональное сообщество о новых актуальных публикациях и исследовательских проектах, а также вовлекать в профессиональное сообщество молодых коллег.

Журнал представляет собой специализированное академическое издание. В нём публикуются материалы, отражающие современное состояние экономической социологии и способствующие развитию данной области в её современном понимании. В числе приоритетных тем: теоретические направления экономической социологии, социологические исследования рынков и организаций, социально-экономические стратегии индивидов и домашних хозяйств, неформальная экономика. Также публикуются тексты из смежных дисциплин - неоинституциональной экономической теории, антропологии, экономической психологии и других областей, которые могут представлять интерес для экономсоциологов.

Журнал публикует пять номеров в год: в январе, марте, мае, сентябре и ноябре. Доступ ко всем номерам журнала постоянный, свободный и бесплатный по адресу: http:// www.ecsoc.hse.ru. Каждый номер содержится в едином файле (10-12 п. л. в PDF).

Журнал входит в список ВАК России, индексируется в Российском индексе научного цитирования (РИНЦ), Emerging Sources Citation Index (ESCI) из Web of Science Core Collection и Scopus.

Требования к авторам изложены по адресу: http://ecsoc.hse.ru/author_requirements. html

В журнале применяется двойное анонимное рецензирование статей. Все материалы проходят через полный цикл редакторской обработки и корректуры.

Плата с авторов журнала не взимается. Ускоренные сроки публикации статей не предусмотрены.

Tournal of Economic Sociology was established in 2000 as one of the first academic e-journals in Russia. It is funded by the National Research University Higher School of Economics (HSE).

Journal of Economic Sociology promotes international standards of research in economic sociology, presenting new research carried out by Russian and international scholars, introducing new books and research projects, and attracting young scholars into the field.

Journal of Economic Sociology is a specialized academic journal representing the mainstreams of thinking and research in international and Russian economic sociology. Journal of Economic Sociology provides a framework for discussion of the following key issues: major theoretical paradigms in economic sociology, sociology of markets and organizations, social and economic strategies of households, informal economy. Journal of Economic Sociology also welcomes research papers written within neighboring disciplines - new institutional economics, anthropology, economic psychology and related fields, which can be of interest for economic sociologists.

Journal of Economic Sociology has a wide Russian speaking audience, living both in Russia and abroad. Its main target group comprises research scholars, university professors, policy-makers, post-graduates, undergraduates and others who are interested in economic sociology.

Journal of Economic Sociology is indexed by Emerging Sources Citation Index (ESCI) from Web of Science ${ }^{\mathrm{TM}}$ Core Collection and Scopus.

Journal of Economic Sociology is a bimonthly journal released in five issues (January, March, May, September, and November). Journal of Economic Sociology provides permanent free access to all issues in PDF. Journal of Economic Sociology applies blind peer-review procedures (two referees for each research paper). All papers are subject to editing, proofreading, and professional design layout.

Guidelines for authors: http://ecsoc.hse.ru/author_requirements.html 
Экономическая социология

T. 18. № 1.

Январь 2017

Электронный журнал www.ecsoc.msses.ru www.ecsoc.hse.ru

\section{ISSN 1726-3247}

Журнал выходит

пять раз в год:

№ 1 - январь

№ 2 - март

№ 3 - май

№ 4 - сентябрь

№ 5 - ноябрь

Учредители:

- Национальный исследовательский университет «Высшая школа экономики»

- В. В. Радаев

Издаётся с 2000 года

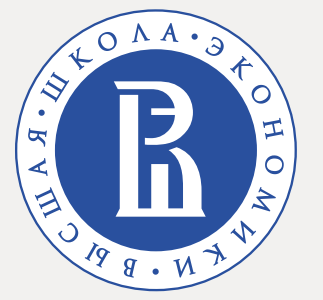

НАЦИОНАЛЬНЫЙ ИССЛЕДОВАТЕЛЬСКИЙ УНИВЕРСИТЕТ

\section{Редакция}

Главный редактор:

Редактор выпуска:

Вёрстка:

Корректор:

Ответственный

секретарь:

Сотрудники

редакции:
Радаев Вадим Валерьевич (НИУ ВШЭ, Россия)

Соколова Татьяна Виленовна (НИУ ВШЭ, Россия)

Мишина Мария Евгеньевна (Россия)

Андрианова Надежда Викторовна (НИУ ВШЭ, Россия)

Котельникова Зоя Владиславовна (НИУ ВШЭ, Россия)

Назарбаева Елена Алексеевна (НИУ ВШЭ, Россия)

Конрой Наталья Викторовна (НИУ ВШЭ, Россия)

\section{Международный редакционный совет}

Ашвин Сара

(Ashwin, Sarah)

Гербер Тед

(Gerber, Ted)

Гусева Аля (Guseva, Alya)

Зависка Джейн (Zavisca, Jane)

Линднер Петер

(Lindner, Peter)

Сводер Кристофер

(Swader, Christopher)

Якубович Валерий

(Yakubovich, Valery)
Лондонская школа экономики и политических наук

(Великобритания)

Висконсинский университет в Мэдисоне

(США)

Университет Бостона (США)

Университет Аризоны (США)

Университет Франкфурта-на-Майне

им. И. В. Гёте (Германия)

Лундский университет (Швеция)

Бизнес-школа ESSEC (Франция)

\section{Редакционный совет}

\section{Богомолова}

Татьяна Юрьевна

Веселов

Юрий Васильевич

Волков

Вадим Викторович

Гимпельсон

Владимир Ефимович

Лапин

Николай Иванович

Малева

Татьяна Михайловна

Овчарова

Лилия Николаевна

Радаев

Вадим Валерьевич

(главный редактор)

Хахулина

Людмила Александровна

Чепуренко Александр Юльевич

Шанин Теодор

Шкаратан Овсей Ирмович
Институт экономики и организации промышленного производства СО РАН (Россия)

Санкт-Петербургский государственный университет (Россия)

Европейский университет

в Санкт-Петербурге (Россия)

НИУ ВШЭ (Россия)

Институт философии РАН (Россия)

Институт социального анализа и прогнозирования РАНХиГС (Россия)

НИУ ВШЭ (Россия)

НИУ ВШЭ (Россия)

Аналитический центр Юрия Левады

(Россия)

НИУ ВШЭ (Россия)

Московская Высшая школа социальных и экономических наук (Россия)

НИУ ВШЭ (Россия) 
Journal of Economic Sociology Vol. 18. No 1. January 2017

Electronic journal www.ecsoc.msses.ru www.ecsoc.hse.ru

\section{ISSN 1726-3247}

Journal of Economic

Sociology is a bimonthly journal released in five issues in annual volume.

No. 1 - January

No. 2 - March

No. 3 - May

No. 4 - September

No. 5 - November

\section{Establishers}

- National Research University Higher School of Economics

- Vadim Radaev

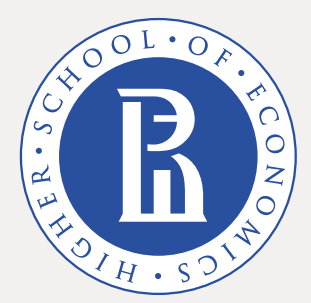

NATIONAL RESEARCH UNIVERSITY

\section{Editors}

Editor-in-Chief:

Editor:

Design and Layout:

Proofreader:

Managing Editor:

Editorial Staff:

Vadim Radaev (HSE, Russia)

Tatyana Sokolova (HSE, Russia)

Maria Mishina (Russia)

Nadezda Andrianova (HSE, Russia)

Zoya Kotelnikova (HSE, Russia)

Elena Nazarbaeva (HSE, Russia)

Natalia Conroy (HSE, Russia)

\section{International Editorial Council}

Sarah Ashwin

Ted Gerber

Alya Guseva

Peter Lindner

Christopher Swader

Valery Yakubovich

Jane Zavisca

\section{Editorial Council}

Tatyana Bogomolova

\author{
Alexander Chepurenko \\ Vladimir Gimpelson \\ Lyudmila Khakhulina \\ Nikolay Lapin
}

Tatyana Maleva

Lilia Ovcharova

Vadim Radaev (Editor-in-Chief)

Theodor Shanin

Ovsey Shkaratan

Yuriy Veselov

Vadim Volkov
The London School of Economics and Political Science (UK)

University of Wisconsin-Madison (USA)

Boston University (USA)

Goethe University Frankfurt (Germany)

Lund University (Sweden)

ESSEC Business School (France)

The University of Arizona (USA)

Institute of Economics and Industrial Engineering of the Siberian Branch of Russian Academy of Sciences (Russia)

HSE (Russia)

HSE (Russia)

Yuri Levada Analytical Center (Russia)

Institute of Philosophy of Russian Academy of Sciences (Russia)

Institute of Social Analysis and Forecasting, The Russian Presidential Academy

of National Economy and

Public Administration (Russia)

HSE (Russia)

HSE (Russia)

Moscow School of Social and Economic Sciences (Russia)

HSE (Russia)

Saint Petersburg State University (Russia)

European University at Saint Petersburg (Russia) 


\section{Содержание}

Вступительное слово главного редактора (B. B. Радаев)

9

\section{Тексты на русском языке}

\section{Новые переводы}

М. Вебер

Хозяйство и общество: очерки понимающей социологии. Общности

\section{Расширение границ}

C. В. Мохов

Управляя неопределённостью и стигмой:

региональный рынок ритуальных услуг в этнографических заметках

\section{Дебютные работы}

Е. А. Бейлина, Д. С. Кантер, А. А. Клементьев, Н. С. Лялина

Мотивы и институциональные условия переработок

(на примере офисных служащих г. Москвы).

\section{Профессиональные обзоры}

\section{Г. Е. Новиков}

Очерк истории потребительского кредита

\section{Новые книги}

\section{Н. В. Конрой}

Странные экономики, в которых мы живём

Рецензия на книгу: Gudeman S. 2016. Anthropology and Economy.

Cambridge: Cambridge University Press. 225 p.

\section{Конференции}

Е. К. Соколова

Свидетели антропологии.

115-я Ежегодная конференция Американской антропологической ассоциации,

г. Миннеаполис, 16-20 ноября 2016 г 


\section{Тексты на английском языке}

\section{Beyond Borders}

\section{Zhdanov}

Post-Authoritarian Devolution: The Case of the First Italian Republic.. 


\section{Contents}

Editor's Foreword (Vadim Radaev) 9

\section{Texts in Russian}

\section{New Translations}

Max Weber

Economy and Society: An Outline of Interpretive Sociology. Organized Groups (an excerpt) 13

\section{Beyond Borders}

\section{Sergei Mokhov}

Handling the Ambiguity and Stigma: Ethnography of a Local Funeral Market

\section{Debut Studies}

Elena Beylina, Daria Kanter, Alexander Klementev, Nadezda Lyalina

Motives and Institutional Conditions of Overwork: Evidence from Moscow Office Workers

\section{Professional Reviews}

Gleb Novikov

An Outline of the History of Consumer Credit

\section{New Books}

\section{Natalia Conroy}

Strange Economies We Live in

Book Review: Gudeman S. (2016) Anthropology and Economy,

Cambridge: Cambridge University Press. $225 \mathrm{p}$

\section{Conferences}

\section{Elena Sokolova}

Evidencing Anthropology.

115th Annual Meeting of the American Anthropological Association,

16-20 November, 2016. Minneapolis, MN. USA 


\section{Texts in English}

\section{Beyond Borders}

\section{Vladimir Zhdanov}

Post-Authoritarian Devolution: The Case of the First Italian Republic.. 


\section{VR ВСТУПИТЕЛЬНОЕ СЛОВО ГЛАВНОГО РЕДАКТОРА}

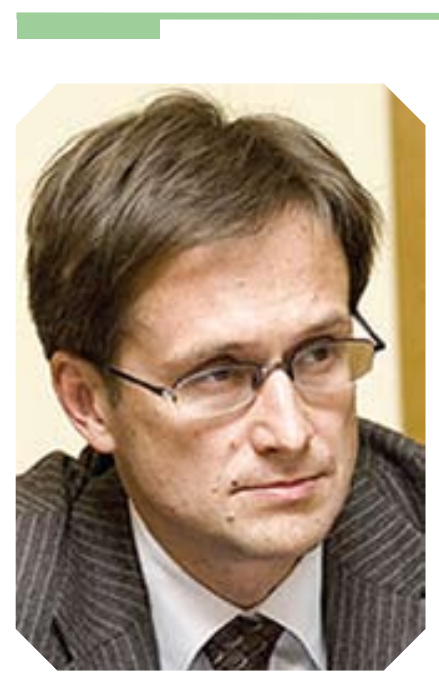

Уважаемые читатели!

Журнал, как заведено, не стоит на месте. В настоящее время идут работы по его переводу на новую технологическую платформу Open Journal System, которая предложит удобный стандартный интерфейс для авторов, рецензентов и редакторов журнала на русском и английском языках. Будем держать вас в курсе событий.

Тем временем предлагаем вашему вниманию первый в 2017 г. номер журнала.

В прошлом номере журнала в рубрике «Новые переводы» мы уже анонсировали выход первого тома фундаментального труда Макса Вебера «Хозяйство и общество: очерки понимающей социологии» в русском переводе. Сочинение издаётся в четырёх томах, и скоро выйдет из печати второй том, первую главу которого мы публикуем. Глава называется «Хозяйственные отношения общностей (хозяйство и общество) в основных чертах». В ней выделяются разные типы общностей на основе зависимости их структуры и экономической функции. Также раскрывается идея закрытия и открытия общностей. В заключении предлагается анализ типов удовлетворения финансовых потребностей общностного действия, в результате чего поднимается вопрос о том, какие из этих типов в большей степени соответствуют рациональному капиталистическому хозяйству. Перевод с немецкого - под редакцией Л. Г. Ионина. Фрагмент текста публикуется с разрешения Издательского дома Высшей школы экономики.

В рубрике «Расширение границ» мы публикуем статью С. В. Мохова (НИУ ВШЭ) о неопределённости и стигматизации на российском рынке ритуальных услуг. В отличие от западной похоронной индустрии, стремящейся к открытости и публичности, представители российского рынка ритуальных услуг избегают любых форм публичности. Это приводит к открытой стигматизации профессии. В статье на основе этнографического полевого исследования в одном из центральных регионов России предпринята попытка описания структуры и особенностей провинциального рынка ритуальных услуг. Дано возможное объяснение закрытости данной структуры и функции самостигматизации.

В рубрике «Дебютные работы» публикуется статья $E$. А. Бейлиной, Д. С. Кантер, А. А. Клементьева u Н. С. Лялиной (студенты НИУ ВШЭ) «Мотивы и институциональные условия переработок (на примере офисных служащих г. Москвы)». Работа посвящена изучению феномена переработок у офисных работников. На основе 22 глубинных интервью показывается, что многие россияне работают больше законодательно закреплённого максимума в 40 час. в неделю. В тексте анализируются мотивы переработок, а также представления офисных работников о «нормальной» продолжительности рабочего дня и о границе между трудом и переработкой. Особое внимание уделено анализу институциональных условий труда (особенностям организационной структуры), которые могут быть причиной возникновения переработок.

В рубрике «Профессиональные обзоры» публикуется очерк истории потребительского кредита, подготовленный $Г$. E. Новиковым (НИУ ВШЭ). Данный обзор представляет собой обобщение и анализ ключевых достижений в пока немногочисленных исследованиях по истории кредита. Очертив проблемное поле дисциплины автор рассматривает институциональные условия формирования современных форм кредитования. Затем анализируется развитие потребительского кредита в США, где ключевыми 
процессами были легализация и легитимация малых займов, распространение продаж в рассрочку и эволюция форм кредитного учёта, и в Европе, где наибольший интерес представляют чековые системы кредитования.

В рубрике «Новые книги» канд. ист. наук Н. В. Конрой (научный сотрудник ЛЭСИ НИУ ВШЭ) предлагает рецензию «Странные экономики, в которых мы живём», посвящённую недавно вышедшей книге Стивена Гудемэна (профессор антропологии Университета Миннесоты, США) «Антропология и экономика» (Gudeman S. 2016. Anthropology and Economy. Cambridge: Cambridge University Press). В книге анализируется баланс корысти (self-interest) и взаимности (mutuality) в экономических отношениях и основывается на широком этнографическом материале. Гудемэн рассматривает пять институциональных сфер - домохозяйства (house), сообщества (community), торговлю (commerce), финансы (finance) и глобальные финансы (meta-finance). Особенность современного рыночного капитализма, по его мнению, заключается в безудержном росте ренты, которая даёт банкам, производителям, продавцам товаров и услуг неконкурентные преимущества, но прикрывается риторикой конкуренции. От возникающего неравенства страдают наименее защищённые участники экономических отношений домохозяйства и сообщества.

В рубрике «Конференции» $E$. $K$. Соколова (аспирант Института этнологии и антропологии имени Н. Н. Миклухо-Маклая РАН) делится своими впечатлениями о 115-й Ежегодной конференции Американской антропологической ассоциации, состоявшейся в Миннеаполисе 16-20 ноября 2016 г. Это одно из наиболее масштабных международных мероприятий, посвящённых антропологии, оно привлекло более 6000 исследователей со всего мира. В обзоре особое внимание уделяется образовательным программам внутри сообщества, а также важности неформальной коммуникации в рамках конференции; особый акцент делается на обращении современной антропологии к массовым коммуникациям, прежде всего - к работе с социальными сетями и блогами.

В разделе на английском языке, в рубрике «Расширение границ», публикуется статья Владимира Жданова (независимый исследователь) «Поставторитарная деволюция: первая Итальянская республика». Автор работы анализирует происхождение, структуру и последствия территориального устройства Италии, где решение проблемы государственности совпало с процессом поставторитарной трансформации. Опыт подобного «договорного перехода» впоследствии был использован в качестве основы для испанской модели демократических реформ. В исследовании прослеживается долгосрочное влияние исторического блока между промышленной буржуазией итальянского Севера и феодалами итальянского Юга, что во многом привело к консервации социально-экономической отсталости южных регионов страны.

Удачи всем в наступившем году! 


\section{VR INTRODUCTORY REMARKS}

Dear colleagues,

The Journal of Economic Sociology continues to develop to meet international standards. At present, the journal is in the process of moving over to a new technological platform - in the form of the Open Journal System - in order to provide a standardized and more convenient bilingual interface for our authors, reviewers, and editors.

Now we turn to the new issue of the journal.

In the last issue, we announced the publication of a new Russian translation of the first volume of Max Weber's seminal study Economy and Society. The second volume of the study is expected to soon be complete. In this issue of the journal, we publish a chapter from the forthcoming volume entitled 'The Economic Relationships of Organized Groups.' In it, different types of organized groups are delineated and Weber distinguishes between open and closed relationships. The chapter concludes with an analysis of five types of want satisfaction by economically active groups. The translation was edited by Leonid Ionin and is being reprinted with the kind permission of HSE Publishing House.

In the section "Beyond Borders, ” we publish Sergei Mokhov's paper on ambiguity and stigma in the Russian funeral market. In contrast to the Western funeral industry that aims to be open, public, and socially responsible, providers of Russian funeral services actively shy away from all forms of publicity. As a result, this profession is largely stigmatized in Russia. The study is based on ethnographic field observations conducted in one of the central regions of the country. The paper describes the structure and specific features of the funeral market in the local context and the author provides an explanation for the closed-off nature of the organized groups and the role of self-stigmatization in this market.

Elena Beylina, Daria Kanter, Alexander Klementev, and Nadezda Lyalina (Department of Sociology, Higher School of Economics) present a study on 'Motives and Institutional Conditions of Overwork: Evidence from Moscow Office Workers.' Their paper examines the phenomenon of office workers overwork. Data collected from 22 in-depth interviews demonstrate that modern Russians tend to work for more than the 40 hours a week that are prescribed by existing legislation. An analysis of the motives behind overwork is provided by paying special attention to the institutional working conditions (organizational characteristics) that can lead to overtime hours.

Gleb Novikov (Department of Sociology, Higher School of Economics) provides 'An Outline of the History of Consumer Credit.' This overview examines the key findings in the small number of studies that currently exist in the field. Institutional conditions that shape various types of credit relationships are considered. These conditions include specific legislation and existing forms of credit, such as pawnshops, small loans, installment credits, family loans, and open-book credits. Cases taken from the USA and Europe are analyzed. In the USA, the study focuses on the legalization and legitimation of small loans, the proliferation of installment payments, and the evolution of credit accounting, whereas in Europe, check credit systems are of major interest.

Natalia Conroy (Laboratory for Studies in Economic Sociology, Higher School of Economics) presents a review of the book by Stephen Gudeman (Professor of anthropology, University of Minnesota) Anthropology and Economy (Cambridge: Cambridge University Press, 2016). The book examines the balance between selfinterest and mutuality in economic relations. It is based on the extensive ethnographic data collected by the 
author and his colleagues during 20th century. Gudeman offers a model of the five institutional spheres: house, community, commerce, finance and meta-finance, in which the combination of the last three characterizes the state of modern capitalism. This capitalism is distinguished by the unrestrained growth of acquired rent bringing non-competitive advantages to banks, manufacturers, and sellers of goods and services, who camouflage their rent-seeking behavior by the competition rhetoric. Less secured households and communities are most affected by the increasing inequality.

Elena Sokolova (the Institute for Ethnography and Anthropology, Russian Academy of Science) shares her observations on the 115th Annual Meeting of the American Anthropological Association (Minneapolis, MN, 16-20 November, 2016) which was one of the biggest international events in anthropology last year, attracting more than 6,000 participants from all over the world. This event is supported by the Society for Cultural Anthropology. The review of the conference pays special attention to the educational programs within the community of anthropologists, the practical importance of informal communication at the conference, and the further exploration of social media tools, such as social networking sites and blogs.

\section{Texts in English}

Vladimir Zhdanov, PhD (independent scholar), presents his paper on 'Post-Authoritarian Devolution: The Case of the First Italian Republic.' The paper examines the origins, the design, and the consequences of territorial arrangements in Italy, i.e., a country in which the settlement of the stateness problem coincided with the process of post-authoritarian transformation. This experience of 'pacted transition' later set the stage for the Spanish model of democratic reform. The study traces the long-lasting impact of the historic bloc between the industrial bourgeoisie of the Italian North and the landlords of the Italian South that contributed to the conservation of the socio-economic backwardness of the latter.

Wishing you all successful 2017 Year! 


\title{
НОВЫЕ ПЕРЕВОДЫ
}

\author{
М. Вебер
}

\section{Хозяйство и общество: очерки понимающей социологии. Общности ${ }^{1}$}

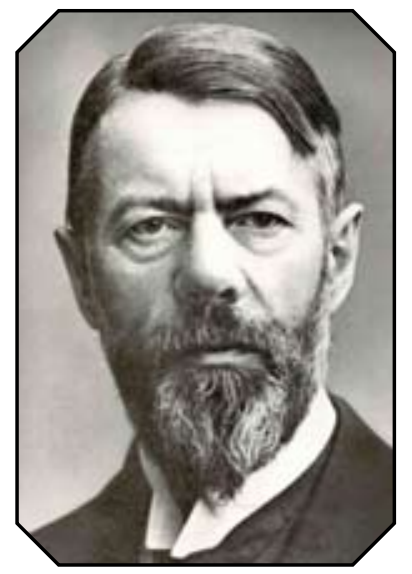

ВEБEP Макс (Weber, Max) (1864-1920) немецкий социолог, философ, историк, экономист.

Перевод с нем.

Л. Г. Ионина

Публикуется

с разрешения

Издательского дома ВШЭ.
Представляемая книга является вторым томом классического труда Макса Вебера "Хозяйство и общество», который впервые переведён на русский язык в полном объёме. В томе II раскрывается становление структур ращиональности, регулирующих функционирование общностей на разных этапах их исторического существования. Здесь даны определения таким кониептам, как домашняя общность, ойкос, этнические и политические образования, в частности партии и государства.

Журнал «Экономическая социология» публикует одну из глав тома II «Общности» — «Хозяйственнье отношения общностей (хозяйство и общество) в основных чертах». Глава вводит в проблематику общностей; в ней выделяются разные типы общностей на основе зависимости их структуры и экономической функции. Также объясняется идея закрытия и открытия общностей. В заключении предлагается анализ типов удовлетворения финансовых потребностей общностного действия, в результате чего поднимается вопрос о том, какие из этих типов в большей степени соответствуют рациональному капиталистическому хозяйству.

Ключевые слова: социология; Макс Вебер; хозяйство; хозяйственные отношения; общность; экономические интересы; формы хозяйства.

\section{Глава 1}

\section{Хозяйственные отношения общностей (хозяйство и обще- ство) в основных чертах}

§ 1. Сущность хозяйства. Хозяйственная, хозяйствующая и регулирующая хозяйство общности

Подавляющее большинство общностей каким-либо образом связано хозяйством. Под хозяйством не следует понимать, как в неспециализированном языке, любое целерационально организованное действие. Так, молитва о духовном благе, в иной религии носящая целесообразный характер, для нас не является актом хозяйствования. Не является таковым и всякое действие или всякое дело, следующее идее бережливости. Держаться при построе-

Источник: Вебер М. 2016. Хозяйство и общество: очерки понимающей социологии: В 4 т. (сост., общ. ред. и предисл. Л. Г. Ионина). Том 2. Общности. М.: Изд. дом Высшей школы экономики. Перевод изд.: Weber М. (1972) Wirtschaft und Gesellschaft. Grundriss der verstehenden Soziologie. 5. revidierte Aufl. Besorgt von Johannes Winckelmann. Tübingen: J. C. B. Mohr (Paul Siebeck). 
нии понятий принципа интеллектуальной экономии, конечно, не значит хозяйствовать. Художник, исходящий из экономии эстетических средств, тоже не хозяйствует, ибо в результате получается крайне неэкономный с точки зрения рентабельности продукт долгой работы по переделке и упрощению. Следование универсальной максиме оптимальности, то есть достижения наибольшего результата при наименьших затратах, также само по себе ещё не хозяйствование, а целерационально ориентированная техника ${ }^{2}$. О хозяйстве можно говорить только в случае, если какой-то потребности (или набору потребностей) соответствует недостаточный, с точки зрения действующего индивида, набор средств и возможных операций по её удовлетворению, и эта ситуация становится причиной особенного ориентированного на неё поведения. Главное, что такая недостаточность осознаётся субъективно и на неё ориентируется действие. Всю дальнейшую казуистику и терминологию мы опускаем.

Хозяйствовать можно в двух разных смыслах. Прежде всего, для удовлетворения имеющейся собственной потребности. Это может быть потребность в любом мыслимом благе, от пищи до религиозного просветления, если её удовлетворению должны служить средства или возможные действия, которых на данный момент для достижения этой цели недостаточно. Вообще, когда речь идёт о хозяйстве, думают обычно о повседневных, так называемых материальных, потребностях. Молитвы и богослужения на самом деле могут быть такими же объектами хозяйства, как и хлеб насущный, если необходимые для их осуществления лица и их действия в дефиците, и получить их можно только за вознаграждение (как и хлеб). Высоко ценимые как предметы искусства рисунки бушменов не являются хозяйственными объектами и, вообще, продуктом труда в экономическом смысле. Но продукты художественного творчества, которые ценятся обычно гораздо ниже, становятся предметами экономического действия при возникновении специфической хозяйственной ситуации - их нехватки в отношении к потребности. Кроме хозяйствования для покрытия собственной потребности есть хозяйствование ради дохода, представляющее собой использование специфической экономической ситуации, состоящей в недостатке желаемых благ, для получения прибыли от распоряжения этими благами.

\section{Социальное действие может по-разному соотноситься с хозяйством³.}

Рационально организуемое действие по своему субъективно подразумеваемому участниками смыслу может быть нацелено на чисто хозяйственный результат - удовлетворение потребности или получение дохода. Тогда оно ложится в основание хозяйственной общности. Также оно может использовать хозяйствование как средство для достижения других результатов, на которые, собственно, нацелено. Тогда это хозяйствующая общность. Или же хозяйственные и нехозяйственные цели в действии связаны друг с другом. Или, наконец, ситуация не соответствует ни одному из этих случаев. Границу между двумя первыми категориями нельзя назвать чёткой. Строго говоря, первое относится только к тем общностям, которые хотят извлечь выгоду из специфической экономической ситуации, то есть хозяйственным общностям, ориентированным на получение дохода. Ибо общности, ориентированные на удовлетворение потребностей, прибегают к хозяйствованию ровно в той мере, в какой оно неизбежно при имеющемся соотношении потребностей и имеющихся для их удовлетворения благ. С этой точки зрения хозяйства семьи, благотворительного фонда, военного комиссариата, коллектива, собравшегося для расчистки леса под пашню или для совместной охоты, все похожи друг на друга. Конечно, кажется,

2 Техника, технология (нем. Тесhnik) - совокупность средств действия в противоположность смыслу действия или его цели; рациональная техника — это применение средств, осознанно и планомерно следующее из опыта и размышления, а при высшей степени рациональности - из научного мышления. О понятии «техника» см. т. 1, гл. 2, § 1, п. 5.

3 Можно согласиться с автором примечаний в американском издании книги Вебера, предположившим, что отмеченная фраза не принадлежит Веберу, а представляет собой позднейшую вставку (см.: [Weber 1978: 354]). Далее в настоящей главе термин «социальное действие» (soziales Handeln) не употребляется, Вебер использует термин «действие общности» или «общностное действие» (Gemeinschaftshandeln). Подробнее эти терминологические тонкости разбираются во вступительной статье к русскому изданию (см.: [Вебер 2016: 26]). 
что различие существует и определяется тем, возникло ли действие общности в силу обстоятельств, с которыми пришлось столкнуться при удовлетворении потребностей (расчистка леса под пашню), или же изначально преследовалась другая цель (подготовка солдат к службе), а необходимость хозяйствовать возникла из недостатка средств для её достижения. На самом деле это очень неопределённое различие, чётко провести его можно, лишь убрав из рассуждения экономическую ситуацию, то есть исходя из предпосылки неограниченности ресурсов, и тогда уже смотреть, останется или не останется действие тем же самым.

Даже в действии общности, которая не является ни хозяйственной, ни хозяйствующей, само его возникновение, существование и тип структуры могут частично определяться хозяйственными причинами, вытекающими из экономической ситуации, то есть быть экономически детерминированными. В свою очередь, оно само может стать фактором, определяющим характер и тип развития хозяйствования, то есть быть экономически релевантным. Обычно и то и другое случается вместе. Отнюдь не редкость действие, которое не представляет ни хозяйственную, ни хозяйствующую общности. Оно легко конституируется в любой совместной прогулке. Также часто встречаются экономически нерелевантные общности. Среди экономически релевантных общностей особую группу образуют те, что, не будучи хозяйственными (их органы не руководят хозяйством непосредственно или путём предписаний, приказов и запретов), регулируют посредством своих порядков экономическое поведение участников: это регулирующие хозяйство общности, и к ним относятся все виды политических, многие из религиозных и огромное количество других общностей, в том числе и специально организованные для целей экономического регулирования (рыболовецкие или марковые товарищества). Общности совсем никоим образом экономически не детерминированные, как уже говорилось, встречаются редко. Но вот степень детерминированности бывает разной; прежде всего отсутствует - вопреки так называемому материалистическому пониманию истории - однозначная детерминация действия общности экономическим фактором. Явления, которые с точки зрения хозяйства тождественны, на самом деле с социологической точки зрения часто связаны со структурными различиями разнообразных общностей, в том числе хозяйственных или хозяйствующих, которые включают их или сосуществуют с ними. Идея о наличии функциональной взаимосвязи между хозяйством и социальными образованиями также есть предрассудок, который невозможно исторически обосновать (если, конечно, под этой идеей понимать однозначную взаимную обусловленность), поскольку структурные формы действия общности развиваются, как мы ещё не раз увидим, по собственным законам да и помимо этого в каждом конкретном случае определяются наряду с хозяйственными и многими другими причинами, придающими им особенный облик. Тем не менее в одном важном пункте хозяйство обычно оказывает важное, можно сказать, решающее причинное воздействие на структуру почти всех - во всяком случае, всех культурно значимых - общностей и, в свою очередь, испытывает влияние структуры действия общности, в которой существует. О том, когда и как это происходит, трудно сказать что-либо существенное в общих словах. Но можно тем не менее высказать некоторые общие соображения о степени избирательного сродства конкретных структурных форм действия общности и конкретных форм хозяйства, то есть о том, поощряют они или, наоборот, исключают либо тормозят друг друга и в какой степени они соответствуют (адекватны) или, наоборот, не соответствуют (неадекватны) друг другу. Такие отношения нам придётся не раз обсуждать впоследствии. И наконец, можно выдвинуть хотя бы несколько общих положений о том, как экономические интересы порождают определённого рода действие общности.

\section{§ 2. Открытые и закрытые хозяйственные отношения}

Один из важных экономических факторов, воздействующих на жизнь любой общности, - конкуренция за экономические возможности, а именно за должностные позиции, клиентуру, рентный или трудовой доход и т. п. С ростом числа конкурентов по отношению к возможностям дохода растёт и заинтересованность участников в том, чтобы как-то ограничить конкуренцию. Обычно это происходит 
следующим образом: берётся некий внешний признак, характерный для части конкурентов (актуальных или потенциальных), - раса, язык, конфессия, географическое или социальное происхождение, родство, место жительства и т. д., и этот признак используется как основание для исключения тех, кто им обладает, из конкурентной борьбы. Каков этот признак в каждом отдельном случае, совершенно не важно, всегда наготове другие из того же ряда. Возникающее таким образом действие одних участников может породить соответствующее действие других, против которых оно направлено. Теперь совместно действующие индивиды, продолжая конкурировать между собой, объединены по отношению ко всем остальным в общность по интересам, у них естественным образом возникает желание создать на этой основе какое-то обобществление, регулируемое рациональным порядком, а если монополистические интересы продолжают существовать и далее, наступает момент, когда либо они сами, либо другие общности, чьи действия могут повлиять на интересы сторон (например, политическая общность), устанавливают порядок, ограничивающий конкуренцию в пользу монополии, и создают из определённого круга лиц постоянные органы, готовые проводить в жизнь этот порядок, пусть даже принудительно. Тогда общность по интересам становится правовой общностью, а её члены - правовыми товарищами. Этот типичный и повторяющийся процесс, который мы назовём закрытием общности, является источником собственности на землю, а также всяких цеховых и прочих групповых монополий. Когда речь идёт о товариществе, то есть о закрытом вовне монополистическом объединении - будь то объединение по месту проживания, чтобы получить исключительное право ловить рыбу в местных водах, или союз дипломированных инженеров, стремящийся иметь для своих — в отличие от «чужих», недипломированных — формальную или фактическую монополию на занятие определённых мест ${ }^{4}$, или закрытие права пользования лугами, пастбищами, короче, альмендой для чужих в интересах жителей одной деревни, либо объединение «торговых служащих» по национальному признаку страны объединение дворян, министериалов, выпускников университетов, ремесленников или претендентов на офицерскую должность, - всегда сначала налицо действие общности, потом чаще всего обобществление, и движущей силой всегда оказывается стремление монополизировать определённые (как правило, экономические) возможности. Такое объединение всегда направлено против конкурентов, обладающих общим позитивным или негативным признаком, и цель его - закрытие в определённой степени соответствующих социальных или экономических шансов для аутсайдеров. Закрытие, будучи осуществлённым, может иметь разные последствия, прежде всего потому, что предоставление монопольных возможностей отдельнымм участникам бывает по-разному организовано. Внутри круга монополистов перспективы бывают полностью открытыми, то есть участники свободно конкурируют между собой, как, например, обладатели профессиональных патентов определённого рода, скажем, дипломированные претенденты на некую должность - за эту должность или ремесленники, имеющие соответствующее свидетельство, - за клиентов или учеников. Или же группа оказывается закрытой и внутри себя; эта закрытость может выражаться в форме ротации, то есть поочерёдного краткосрочного назначения на доходные должности, либо в предоставлении неких привилегий с возможностью их отзыва, к примеру права распоряжения пахотной землёй в «сильных» земельных общинах типа русского «мира», либо в передаче определённых возможностей в пожизненное распоряжение; последнее, как правило, касается всех пребенд, должностей, монополий ремесленных союзов, альменды, особенно также первоначального разделения угодий в большинстве общинных деревенских союзов и т. п. Bнyтренняя закрытость, далее, может выражаться в том, что привилегии безвозвратно передаются индивиду и его наследникам, но без права уступки их другим лицам либо с ограничением претендентов

4 Вебер имеет в виду реальный «Союз немецких дипломированных инженеров», основанный в июле 1909 г. как сословное представительство инженеров с высшим образованием (окончивших университеты, высшие технические школы), полагавших, что в существовавшем уже долгое время «Объединении немецких инженеров» их интересы не представлены должным образом; см.: [Weber 2001: 83].

5 Основанный в 1893 г. «Немецкий союз торговых служащих» уже через два года (в 1895 г.) был переименован в «Немецконациональный союз торговых служащих»; см.: [Weber 2001: 83]. 
на уступку кругом общинных товарищей (это $\chi \lambda \eta ́ р о \varsigma^{6}$, военные пребенды древности, служебные лены министериалов, наследственные должностные и ремесленные монополии). Или, наконец, «закрытым» остаётся только общее количество возможностей, но каждая из них может быть приобретена третьим лицом у их нынешнего владельца без согласия и уведомления остальных наподобие акций на предъявителя. Эти разные формы более или менее выраженного внутреннего закрытия общности можно считать стадиями апроприации монополизированных общностью социальных и экономических возможностей. Полное освобождение присвоенных монопольных возможностей с перспективой их обмена также и вовне, то есть превращение их в полностью свободную собственность, означает, естественно, подрыв прежнего монопольного сообщества, а апроприированные права распоряжения, как его caput mortuum ${ }^{7}$, теперь уже оказываются в руках отдельных индивидов в качестве приобретённых в процессе рыночного оборота прав, поскольку вся без исключения собственность на натуральные блага исторически возникла из постепенной апроприации монополистических товарищеских долей, и объектом её были, в отличие от сегодняшней ситуации, не только конкретные вещные блага, но также экономические и социальные возможности всех мыслимых видов. Само собой разумеется, степень и способ апроприации и лёгкость осуществления этого процесса внутри общности различаются в зависимости от технической природы объектов и возможностей, о которых идёт речь; эти объекты в разной степени удобны для присвоения. Возможность, например, получить с поля путём его обработки продукты, используемые для поддержания жизни или извлечения дохода, связана с видимым и чётко ограниченным вещным объектом, то есть с самим конкретным и неизменным по величине полем, что, например, совсем не так в случае увеличения дохода путём расширения круга клиентов. Тот факт, что объект приносит доход только благодаря мелиорации, то есть в известном смысле сам является продуктом труда того, кто его использует, наоборот, не мотивирует присвоение. То же самое происходит и в случае приобретения клиентуры, пусть в иной форме, но в гораздо большем масштабе. Чисто технически клиентуру нельзя, так сказать, «приписать» себе так же просто, как участок земли. Естественно, и степень присвоения оказывается очень разной. Но важно твёрдо установить, что апроприация, в принципе, всегда представляет собой один и тот же, хотя с разной быстротой и лёгкостью осуществляемый процесс, а именно закрытие монополизированных социальных и экономических возможностей также и внутри самой общности, то есть по отношению к товарищам. В соответствии с этим общности являются в разной степени открытыми или закрытыми как внутри себя, так и по отношению к внешнему миру.

\section{§ 3. Формы общностей и экономические интересы}

Рассмотренная выше тенденция монополизации принимает особые формы там, где происходит формирование общностей из людей, отличающихся от других в силу неких особых качеств, npиобретаeмblx благодаря воспитанию, обучению или специфике деятельности. Это могут быть люди, имеющие определённый экономический статус, равное или схожее служебное положение, практикующие рыцарский, аскетический или другой особенный стиль жизни либо как-то ещё отличающиеся от других. Действие общности, стремящейся к обобществлению, обычно принимает форму цеха или гильдии. Ограниченный круг полноправных членов монополизирует распоряжение соответствующими идеальными, социальными экономическими благами, обязанностями и жизненными позициями как «профессию». Целиком и полностью к исполнению профессии допускаются лишь те, кто (1) прошёл ученичество и получил правильную начальную подготовку, (2) выдержал испытание и доказал свою квалификацию, (3) имел, возможно, другие направления подготовки и располагает другими навыками. Эта процедура в типичной форме воспроизводится в самых разных общностях - от пеналистских ${ }^{8}$ обобществлений

6 Хй́ро (греч.) - часть, доля, пай, парцелла, наследственная доля в земельной собственности.

7 Caput mortuum (лат.) — «мертвая голова», алхимический термин, обозначающий остаток после алхимических операций, то, что остается, когда из вещества извлечено всё, составляющее его ценность.

8 Пенализм (от лат. Penna - перо и нем. Pennal - пенал, коробка для перьев) - система самоорганизации студенчества в Средние века, похожая на нынешнюю «дедовщину»; «пеналами» звали младших школьников и студентов младших 
студенчества до рыцарских объединений, с одной стороны, и ремесленных цехов - с другой, а также в квалификационных требованиях к современным чиновникам и служащим. При этом, конечно, важна перспектива достижения профессионального успеха, в чём идеально и материально заинтересованы все участники, несмотря на сохраняющуюся конкуренцию между ними: для ремесленников важна добрая слава их товаров, для министериалов и рыцарей - признание их усердия господином и собственная военная безопасность, сообщества аскетов озабочены тем, как бы путём неправильных манипуляций не навлечь на себя гнев богов и демонов (например, у некоторых первобытных народов того, кто сфальшивит в ритуальном гимне или танце, убивали во искупление вины перед богами). Но ещё важнее обычно возможность ограничения таким способом числа претендентов на доходы и привилегии, связанные с профессиональной позицией. Ученичество и испытания, как и доказательства мастерства, и всё, что требуется помимо этого (например, щедрое одаривание товарищей), - это часто, скорее, экономические, нежели собственно квалификационные, требования к претендентам.

Монополистические тенденции и связанные с ними экономические соображения сыграли исторически важную роль в торможении экспансии общностей. Например, политика аттической демократии в области прав граждан, состоящая во всё большем ограничении круга обладателей гражданских привилегий, стала барьером на пути её политической экспансии. Констелляция экономических интересов, хотя и иного, но схожего рода, остановила пропаганду квакерства. Изначальное религиозно мотивированное стремление обращать покорённые народы в исламскую веру было ограничено экономическими интересами завоевателей, состоящими в сохранении неисламского, то есть неполноправного населения, на которое возлагались тяготы и повинности по содержанию правоверных, — явление, типичное для многих подобного рода ситуаций.

Не менее типичен другой случай, когда индивиды, которые живут (как в духовном, так и в экономическом смысле) тем, что представляют интересы общности или каким-то иным образом участвуют в её жизни, тем самым пропагандируют и развивают действие общности, на основе чего формируется обобществление, которого иначе могло бы не быть. В идеальном смысле такой интерес мотивируется по-разному. Например, романтики и их последователи в XIX веке пробудили в многочисленных гибнущих языковых общностях «интересных» для них народностей заботу об их, этих народностей, собственном языковом наследии. Немецкие гимназические и университетские профессора занимались мелкими славянскими языковыми общностями, писали о них книги, испытывая возвышенное стремление спасти их от полного исчезновения. Но всё-таки чисто идейная мотивация - не столь мощный рычаг, каким может быть экономическая заинтересованность. Например, группа людей платит или как-то ещё прямо или косвенно вознаграждает усилия человека, который берёт на себя и осуществляет представительство, то есть формулирование и пропаганду интересов этой группы, в результате чего возникает обобществление, при любых обстоятельствах оказывающееся надёжной гарантией дальнейшего действия общности. Идёт ли речь, к примеру, о платной пропаганде (замаскированной или открытой) сексуальных ${ }^{9}$ либо других «нематериальных» или же экономических интересов (профсоюзов, союзов работодателей и т. д.), работают ли «докладчики» или митинговые ораторы на почасовой основе либо «секретари» на зарплате и т. п., всегда находятся люди, профессионально занимающиеся сохранением имеющихся и привлечением новых членов. Планомерное рациональное предприятие ${ }^{10}$

курсов, которые первое время не считались равноправными учениками и студентами, были обязаны прислуживать старшим и терпеть поношение и поругание с их стороны. В немецких университетах в выраженной форме просуществовал до XVIII века.

9

Очевидно, Вебер имеет в виду пропаганду интересов женщин в рамках раннего феминизма, в том числе социалистического и марксистского, а также суфражизма.

10 Предприятие (нем. Betrieb) - непрерывное целеориентированное действие, которое может иметь хозяйственную, религиозную или какую-либо иную направленность. Предприятие в сфере хозяйственно ориентированного действия техническая категория, означающая способ непрерывного соединения определённых трудовых усилий между собой и 
приходит на смену прерывисто-иррациональному случайному действию и продолжает функционировать, даже если первоначальный энтузиазм самих инициаторов давно иссяк.

Собственно капиталистические интересы могут продвигаться в пропаганде самых разных действий общности. Например, владельцы больших запасов печатных материалов на фрактуре ${ }^{11}$ заинтересованы в дальнейшем использовании этого патриотического шрифта. Трактирщики, предоставляющие, несмотря на бойкот военных, помещения под собрания социал-демократов, заинтересованы в росте числа членов партии ${ }^{12}$. Каждый найдёт множество таких примеров применительно к любого рода действиям общности.

Но во всех случаях экономической заинтересованности (всё равно, идёт ли речь о служащих или о капиталистической верхушке) налицо важная закономерность: интерес к содержанию пропагандируемых идеалов - в чём бы они ни состояли - неизбежно уступает место интересу к поддержанию или пропаганде общности как таковой. Отличным примером здесь служит полное исчезновение содержательных идеалов у американских партий. Но ещё лучший пример, конечно, это типичное, происходящее с самых давних пор сращивание капиталистических интересов с экспансионистскими интересами политических общностей. С одной стороны, политические общности имеют возможности мощного влияния на экономическую жизнь, а с другой - они принудительно получают в своё распоряжение гигантские средства, на чём можно прямо или косвенно зарабатывать: прямо - путём оказания вознаграждаемых услуг и предоставления кредитов; косвенно - путём эксплуатации политически оккупированных ими объектов. В Античности и в начале Нового времени центр тяжести капиталистических доходов, извлекаемых из союза с политической властью, находился в империалистической эксплуатации, и сегодня он снова сдвигается в том же направлении. Любое расширение державной власти увеличивает шансы получения прибыли для заинтересованных участников ${ }^{13}$.

Эти экономические интересы, ориентированные на экспансию общности, вступают в конфликт с интересами, которые, следуя в русле уже описанных монополистических тенденций, наоборот, питаются её закрытостью и исключительностью. Ранее мы установили в общих чертах, что почти каждый основанный на добровольном членстве целевой союз стремится, помимо достижения первичного результата, на который ориентировано обобществлённое действие, к установлению между своими членами специфических отношений, способных при определённых обстоятельствах стать основой действия общности, направленного на достижение совершенно иных целей, то есть обобществление постоянно привязывается к более глубокой «охватывающей» общности. Конечно, это справедливо только для части обобществлений, а именно для тех, где действие общности предполагает не только чисто деловой, но и личностный, социальный контакт. Например, человек принимается в акционеры без всякой оглядки на его личностные, человеческие качества и, как правило, независимо от желания и согласия других акционеров, а лишь в силу совершения экономического акта обмена денег на акции. То же относится

с вещественными средствами производства. Его противоположностью является либо (а) непостоянное, либо (b) технически не непрерывное действие. Именно эти «технические» характеристики (целерациональность и непрерывность) объясняют, почему Вебер характеризует как предприятие также многие структуры, никак не связанные с экономикой, в частности, церковь и государство, которое он определяет термином Anstaltsbetrieb (букв. учрежденческое предприятие).

11 Фрактура (от нем. Fraktur - надлом, излом) - разновидность готического письма, возникшая в Германии в XVI веке и широко использовавшаяся вплоть до первой половины XX века. В противоположность антикве - привычному ныне шрифту из более округлых букв с засечками - фрактура считалась выражающей германский дух. Уже в XVIII веке она воспринималась как народное письмо, а антиква — как письмо интеллектуалов.

12 В Германском рейхе солдатам было запрещено посещать пивные и рестораны, где проводились собрания социалдемократов; этот запрет приняли также многие союзы ветеранов. Хозяева восполняли убытки, предоставляя помещения под собрания Социал-демократической партии Германии (СДПГ).

13 Подробнее об этом см. гл. 6, § 4 «Хозяйственные основы “империализма”» настоящего тома. 
ко всем обобществлениям, где вступление зависит от выполнения некоего формального условия или процедуры и не сопровождается проверкой личности претендента. Это характерно для некоторых видов чисто хозяйственных общностей, а также для политических объединений и - в общем и целом становится правилом в случаях, когда цель объединения имеет рациональный, специализированный характер. И всё же среди обобществлений есть много таких, где, с одной стороны, членство предполагает (открыто или по умолчанию) наличие у претендента определённых специфических качеств и, с другой стороны, в связи с этим постоянно возникает та самая глубокая «охватывающая» общность. Особенно это очевидно там, где приём нового коллеги обусловлен проверкой и получением согласия каждого из членов. В таких случаях претендент проверяется не только на предмет соответствия своим предполагаемым функциям и наличия необходимых для объявленных целей союза способностей, но и на предмет того, что он представляет собой как личность. Здесь не место классифицировать обобществления по признаку важности или, наоборот, неважности для них личностно ориентированного отбора. Достаточно сказать, что таковой действительно встречается в обобществлениях самого разного рода. Не только религиозная секта, но и товарищеское объединение типа союза однополчан или даже игроков в кегли не примет в свои ряды того, кто не устраивает его членов по своим человеческим качествам. Но если уж такой человек принят, он оказывается легитимирован вовне, то есть по отношению к третьим лицам, гораздо сильнее, чем когда он просто обладает качествами, важными для целей союза. Участие в действии общности в этом случае даёт ему возможность включиться в связи, более глубокие и сильные, чем те, что обещает объявленная цель союза, и использовать эти связи к собственной выгоде. Поэтому часто люди входят в религиозные, студенческие, политические или какие-то ещё союзы, совершенно не интересуясь целями, которые те формально преследуют, а рассчитывая на экономически важные легитимации и отношения, возникающие в силу членства. Если эти мотивы побуждают посторонних присоединяться к общности и способствуют ее расширению, то интересы членов, наоборот, состоят в том, чтобы монополизировать своё преимущество и повысить его экономическую ценность путём сведения к узкому эксклюзивному кругу участников. И чем круг у́же и эксклюзивнее, тем выше становится, помимо прямой полезности, и социальный престиж членства.

Наконец, нужно коротко остановиться ещё на одном часто встречающемся проявлении связи хозяйства с действием общности: на обещаниях конкретных экономических выгод в целях сохранения и расширения изначально нехозяйственной общности. Это, естественно, чаще всего происходит там, где несколько однотипных общностей конкурируют в борьбе за новых членов, - например, среди политических партий или религиозных общин. Американские секты конкурируют между собой, организуя культурные и прочие, например спортивные, мероприятия и постоянно снижая цену вступления в новый брак для разведённых супругов (такого рода демпинг с недавних пор стал ограничиваться путём создания настоящих «картелей»). Религиозные и политические партии помимо пикников и других встреч организуют так называемые молодёжные союзы, женские группы и проч., а также активно участвуют в чисто коммунальных и других, по сути, неполитических мероприятиях, что даёт им возможность, конкурируя между собой, оказывать услуги экономического свойства заинтересованным лицам и общинам. Внедрение партийных, религиозных и других групп в коммунальные, товарищеские и другие подобные общности имеет сильную экономическую мотивацию: функционеры получают тёплые местечки и повышают свой престиж, одновременно им удаётся переложить на другие организации собственные аппаратные издержки. Для этого вполне подходят должности в муниципалитетах, товариществах, потребительских обществах, больничных кассах, профсоюзах и т. п., но в ещё большей степени - политические должности и «кормления» либо другие распределяемые политической властью социальные или иные позиции, ценимые как источник обеспечения, в частности университетские профессуры. Парламентская система даёт любой общности, если она достаточно велика, возможность обеспечить таким образом своего вождя и членов. В частности, это относится к политическим партиям, которым такой род обеспечения свойствен по самой их сути. Нам важно специально отметить тот факт, что нехозяйственные общности прибегают и к прямому созданию экономических организаций, 
особенно для целей пропаганды, чему служат многие из нынешних милосердных учреждений разных конфессий, в ещё большей степени - христианские, либеральные, социалистические, национальные и прочие профсоюзы и кассы взаимопомощи, дающие возможность поддержки и страхования, в значительной степени также основанные именно для этих целей потребительские союзы и товарищества. В некоторых итальянских товариществах, чтобы получить работу, нужно предъявить справку о «прохождении» исповеди. У поляков в Германии необычайно широко распространились организации по кредитованию, долговым выплатам, устройству польских переселенцев; русские партии всех направлений в революционный период ${ }^{14}$ сразу систематически вступили на этот современный путь. Практикуется также создание доходных предприятий, не только финансовых или сервисных — банков, отелей (социалистический Hôtell-erie du Peuple ${ }^{15}$ в Остенде), — но даже производственных (тоже в Бельгии). Группы, обладающие властью в политических общностях, то есть собственно чиновничество, для сохранения своих властных позиций делают то же самое - от организации «патриотических» объединений, участие в которых оказывается экономически выгодным, до создания бюрократически контролируемых кредитных организаций («Прусская касса» $\left.{ }^{16}\right)$. Анализ технических подробностей этих форм пропаганды не входит в нашу задачу.

Мы описали лишь в общих чертах и показали на нескольких особенно типичных примерах способы взаимодействия и противоборства экспансионистских, с одной стороны, и монополистических - с другой, экономических интересов внутри разных сообществ. Глубже входить в детали мы не можем, для этого необходимо специальное исследование всех отдельных видов обобществлений.

\section{§ 4. Типы экономической деятельности хозяйствующих общностей и формы хозяйства}

Речь пойдёт о связи действия общности с хозяйством, обусловленной тем, что исключительно большое число общностей являются хозяйствующими. Для того чтобы они могли быть таковыми, обыкновенно требуется определённая степень рационального обобществления. Хотя это и необязательно: его нет в структуpax, вырастающих из домашних общностей, которые мы опишем далее ${ }^{17}$, но обычно оно имеется.

Действие общности, поднявшейся до уровня рационального обобществления, требует наличия экономических благ и услуг, а следовательно, и некоего формально установленного правила их мобилизации. Эта последняя может осуществляться по схемам, показанным ниже, структурно представляющим собой чистые типы (примеры по возможности мы берём из жизни политических сообществ, ибо именно здесь имеются самые развитые системы мобилизации ресурсов).

1) Получение благ и услуг по типу ойкоса, то есть чисто общинного и чисто натурального хозяйства с обязательным прямым личным физическим участием всех его членов, регулируемым чёткими правилами, едиными для всех или специфицированными (общая воинская повинность для всех годных к военной службе и особый род хозяйственной службы для ремесленников). Обязательна также сдача материальных благ, необходимых для удовлетворения потребностей (например, к столу князя или для военной администрации), которая происходит в форме фиксированных сборов в натуральном виде. Продукты используются в том же работающем не на рынок общинном хозяйстве, представляющем собой часть действия общности (например, чистое самодостаточное домохозяйство князя или феодала,

14 1905-1907 гг. Глава писалась в 1913 г.

15 «Народный отель» (франщ.).

16 «Прусская касса» (нем. Preußenkasse) - общепринятое бытовое обозначение основанной в 1895 г. так называемой Прусской центральной товарищеской кассы, выступающей как кредитный институт, обслуживающий мелкие крестьянские и ремесленные хозяйства. Капитал кассы обеспечивался правительством Пруссии.

17 См. гл. 2, § 1 настоящего тома. 
то есть чистый тип ойкоса, или особый, полностью основанный на натуральных услугах и взносах порядок военного управления, близкий древнеегипетскому).

2) Путём сборов или (рыночно) обложения членов общины обязательными налогами и регулярными или связанными с определёнными событиями платежами в денежной форме по определённым правилам, что даёт возможность получать средства удовлетворения потребностей на рынке, то есть путём покупки вещных орудий производства и найма работников, чиновников и солдат.

Сборы также могут иметь характер контрибуций, когда обложению подлежат все индивиды, даже те, кто не участвует в действии общности, но при этом (а) пользуется на условиях особого возмещения (оплаты в техническом смысле слова) возможностями и преимуществами жизни в общине, в частности услугами созданных ею общественных структур (земельный кадастр или другие учреждения) и хозяйственных благ (например, построенное общиной шоссе), (b) просто физически оказался в сфере фактической власти общности (налогообложение проживающих на определённой территории, таможенные сборы с людей и товаров при пересечении территории).

3) Путём извлечения дохода, то есть сбыта на рынке продуктов или услуг собственного производства, которое является составной частью действия общности и доход от которого используется на общественные цели. Это может быть свободное предприятие без формального монопольного статуса (Preußische Seehandlung ${ }^{18}$, Grande Chartreuse ${ }^{19}$ ) или монополистическое предприятие, каких множество как в прошлом, так и в настоящем (почта).

Ясно, что эти три в понятийном смысле наиболее чистых типа могут соединяться в любые комбинации. Услуги в натуральной форме могут быть оплачены деньгами, натуральные продукты - обращены в деньги на рынке, материальные продукты доходного производства - обменены на то, что получено путём натурального оброка, или куплены на рынке на средства от налогов и денежных сборов. Составные части отдельных типов могут как угодно комбинироваться, что и происходит на деле.

4) Получение ресурсов путём меценатства, то есть чисто добровольных взносов со стороны тех, кто имеет средства и каким-либо образом материально или идейно заинтересован в цели общностного действия, не являясь при этом обязательно членом союза (фонды для религиозных целей как типичная форма удовлетворения потребностей в религиозных и политических группах; поддержка партий крупными спонсорами; сюда же относятся и ордены нищенствующих, и добровольные подношения князьям в прошлом). В таких случаях отсутствуют определённые права и обязанности, как и связь объёма вложений с другими формами участия, меценат может вообще не входить в круг действующих.

5) Путём (позитивно или негативно) привилегированного обременения.

а) Позитивно привилегированное обременение возникает (не только, но главным образом) в случае предоставления определённой социальной или экономической монополии либо, наоборот, защиты от таковой, когда некоторые привилегированные сословия или монопольные группы частично либо полностью освобождаются от уплаты сборов. Иначе говоря, сборы и услуги востребуются не по общему правилу, в соответствии с уровнем дохода и размером состояния или (как минимум, в принципе) с видом имущества и получения дохода, а в связи со специфи-

18 Preußische Seehandlung (нем.) - торговое общество «Прусская морская торговля», организованное Фридрихом II в 1772 г. Не будучи монополией, оно пользовалось весомыми привилегиями государства. В 1904 г. было преобразовано в Прусский государственный банк, который ликвидирован в 1947 г. с упразднением Пруссии как государства.

19 Grande Chartreuse (франц.) — католический монастырь Гранд-Шартрёз во Франции, обитель ордена картезианцев; место создания рецепта и производства известного одноимённого ликёра. 
ческими экономическими, политическими либо иными властными позициями и монополиями, которые общность предоставила и гарантировала индивидам или группам (владение поместьем, цеховые и сословные налоговые привилегии или специальные сборы) как коррелят или прямой результат этой самой монополии или апроприации. Такой способ удовлетворения потребностей создаёт или фиксирует монополистическую иерархию внутри общности путём закрытия социальных и экономических возможностей для отдельных слоёв.

В понятийном смысле к этой же форме удовлетворения потребностей надо отнести как важный особый случай весь спектр форм феодального или патримониального покрытия потребностей в политических средствах власти, которые сами связаны с апроприированными властными позициями по отношению к обобществлённому действию (князь как таковой в сословной системе должен покрывать расходы политического действия общности из своего патримониального состояния; феодальные носители политической или патримониальной власти и социальной чести - вассалы, министериалы и проч. - покрывают административные и военные расходы из собственных средств и т. п.). Речь идёт в основном о взносах и услугах, предоставляемых $i n$ natura (сословно-натуральное привилегированное удовлетворение потребностей). Но аналогичные процессы привилегированного удовлетворения потребностей могут иметь место и при капитализме, когда, например, политическая власть гарантирует группе предпринимателей прямо или косвенно монополию в области их деятельности, за что налагает на них контрибуцию единовременно или в форме регулярных отчислений. Эта распространённая в эпоху меркантилизма форма привилегированного обременения ныне вновь играет всё более значимую роль (налог на спиртное в Германии).

b) Негативно привилегированное удовлетворение потребностей имеет литургическую природу. В случае классовой литургии 20 обязанность предоставления дорогостоящих услуг определённого характера связывалась с определённым размером чистого, не имеющего монопольных привилегий состояния, будучи возлагаемой, иногда по очереди, на всех обладателей такового (триерархи и хореги в Афинах, принудительные откупа в эллинистических государствах). В случае сословной литургии учитывается связь облагаемых повинностями лиц с определёнными монопольными сообществами так, что они не могут уклониться от требуемых вложений, не подставляя под удар сообщество (солидарная ответственность). Это принудительные цеха и гильдии в Древнем Египте и поздней Античности; это наследственные обязательства русских крестьян перед отвечающей за уплату налогов сельской общиной; это более или менее сильная привязанность к земле колонов и крестьян всех времён и солидарная ответственность общин за сбор налогов и (иногда) призыв новобранцев; это, наконец, солидарная ответственность римских декурионов за назначенные выплаты.

Названные в п. 5 способы удовлетворения потребностей общности по природе своей ограничены кругом принудительных общностей учрежденческого типа (прежде всего политических).

\section{§ 5. Действия общности по удовлетворению потребностей и распределение бремени. Порядки, регулирующие хозяйство}

Способы удовлетворения потребностей, возникающие в результате борьбы интересов, часто имеют важное значение безотносительно к их прямой цели, ибо нередко они порождают регулирующие хозяйство порядки (например, названные в последнем из приведённых выше пунктов) и даже там, где

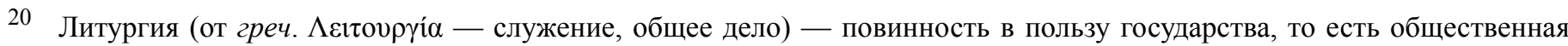
обязанность, или повинность, которую граждане или группы граждан исполняют лично либо путём принятия на себя всех связанных с этим затрат. 
это прямо не происходит, оказывают глубокое влияние на развитие и ориентацию хозяйства. Так, например, сословно-литургическое удовлетворение потребностей ведёт к закрытию социальных и экономических возможностей, к закреплению сословной структуры и тем самым затрудняет формирование частных капиталов. То же самое происходит и в случаях преобладания общинно, доходно или монопольно ориентированных типов удовлетворения потребностей общности. При первых двух из перечисленных в предыдущем параграфе вариантах постоянно налицо тенденция к исключению хозяйства, ориентированного на частный доход, при двух последних - тенденция к сдвигу, иногда — в сторону стимулирования, иногда - в сторону ограничения возможностей частнокапиталистической прибыли. Это зависит от обстоятельств, а также от степени, формы и направленности поощряемого государством монополизма. Нарастающее влияние сословно-литургического (а также и в определённой степени общинно-хозяйственного) удовлетворения потребностей в Римской империи удушило античный капитализм. Современные доходные общинные государственные предприятия отчасти отодвигают, отчасти вытесняют капиталистические; тот факт, что немецкие биржи со времени огосударствления железных дорог не торгуют их акциями, не только важен с точки зрения их собственного положения, но и влияет на способ формирования состояний. Любое поощрение монополий и их стабилизация, связанные с государственными контрибуциями (немецкий налог на спиртоводочные изделия и т. п.), препятствуют экспансии капитализма (пример: возникновение чисто ремесленных винокурен). В Средневековье и в начале Нового времени колониальная и торговая монополии, наоборот, стимулировали прежде всего возникновение капитализма, поскольку в тех условиях только монополизация создавала поле возможностей для ориентированного на прибыль капиталистического предпринимательства. Однако в дальнейшем (уже в Англии XVII века) монополизация работала против интересов рентабельности капитала, ищущего оптимальные возможности вложения, в результате чего столкнулась с агрессивной оппозицией, которая её и погубила. Так что в случае обусловленных налогами монопольных привилегий влияние их на становление капитализма неоднозначно. Зато однозначно идёт на пользу капиталистическому развитию удовлетворение потребностей через обложение налогами и рынок, когда - в крайнем идеальном случае - все потребности, в том числе управленческие, удовлетворяются путём вынесения на свободный рынок, то есть, например, частному предпринимателю передаётся вербовка и обучение армии (кондотьеры в начале Нового времени), а средства обеспечиваются путём сбора налогов в денежной форме. Такая система, безусловно, предполагает полностью развитую денежную экономику и наличие с точки зрения техники управления строго рационального и чётко функционирующего (а это значит, бюрократического) управленческого механизма. Особенно это касается налогообложения движимого имущества, которое везде, и прежде всего при демократии, сталкивается с большими сложностями. На этих сложностях нужно кратко остановиться, ибо в условиях западной цивилизации они в значительной мере обусловили развитие специфически современного капитализма. Любой вид обременения имущества как такового повсюду, даже там, где власть находится в руках неимущих, наталкивается на определённые границы, это связано с тем, что владелец имущества может покинуть общность. Вероятность такого шага определяется, естественно, тем, насколько неизбежна принадлежность индивида именно к данной общности, а также тем, насколько его связь именно с этой общностью диктуется специфическим характером имущества. В принудительных общностях учрежденческого характера, то есть в первую очередь в политических образованиях, все приносящие доход возможности использования имущества особенно сильно связаны с владением землёй и являются специфически неперемещаемыми, в противоположность движимому, то есть состоящему в деньгах или в легко обратимых в деньги вещах и не соотнесённому с определённым местоположением имуществу. Выход обладателей такого имущества из состава общности и их перемещение за её пределы не только резко увеличивает бремя налогов на остающихся членов, но способен - в общности, основанной на рыночном обмене, особенно на обмене на рынке труда, — так ухудшить шансы получения дохода для неимущих (прежде всего получения работы), что общность, только чтобы избежать таких последствий, может отказаться от обложения владельцев этого имущества в свою пользу и даже сознательно предоставить им привилегии. Произойдёт ли это, зависит от экономической структуры кон- 
кретной общности. Для античного демоса, который в значительной мере жил за счёт дани с подданных и при хозяйственном укладе, где рынок труда в современном смысле слова ещё не определял классовое положение масс, названные мотивы и стимулы были гораздо слабее, чем привлекательность прямого взимания налогов с имущества.

В современных условиях чаще всего дело обстоит противоположным образом. Именно общности, где неимущие слои имеют решающий голос, нередко весьма бережно обращаются с имуществом. Коммуны, управляемые социалистическими партиями (например, Катания на о. Сицилия), дают широкие привилегии фабрикам, ибо расширение возможностей трудоустройства, то есть прямое улучшение собственного классового положения, для их сторонников важнее, чем так называемое справедливое распределение и налогообложение имущества. Домовладельцы, хозяева участков под застройку, мелкие торговцы, ремесленники, несмотря на противоречия интересов в каждом отдельном случае, тоже обычно стремятся учитывать прежде всего ближайшие интересы, определяемые классовым положением, поэтому в любого рода общностях меркантилизм есть общераспространённое, в отдельных случаях весьма гибкое и предстающее в самых разных формах явление. Точно так же потребность в сохранении налогового потенциала и наличии крупных состояний, способных к предоставлению кредитов, вынуждает к подобному обращению с движимым имуществом и тех, кто заинтересован в могуществе собственной общности как таковой по сравнению с ей подобными. Поэтому движимое имущество, даже если власть в общности находится в руках неимущих, имеет шанс если не получения прямых меркантилистских привилегий, то масштабного освобождения от литургического и налогового бремени там, где существует значительное число конкурирующих между собой общностей, в которых владелец имущества может обосноваться, как, например, в отдельных штатах Северо-Американского союза, где партикуляристская самостоятельность есть главная причина крушения всех серьёзных попыток объединения на основе потребностей капитализма, или — в ограниченном, но тем не менее ощутимом объёме - в коммунах в рамках одной страны, или, наконец, в полностью и совершенно независимых конкурирующих друг с другом политических образованиях.

В целом же, естественно, способ распределения бремени в значительной мере определяется, с одной стороны, расстановкой сил различных групп внутри общности, а с другой - типом экономического порядка. Всякое возрастание или преобладание натурально-хозяйственного удовлетворения потребностей ведёт к литургической системе. Так, египетская литургическая система возникла во времена фараонов, а позднеримское литургическое государство развивалось по египетскому образцу благодаря натурально-хозяйственному характеру завоёванных внутренних областей и относительно убывающему весу и значению капиталистических слоёв, что, в свою очередь, было обусловлено изменением структур господства и управления по мере упразднения налоговых откупов и ограничения ростовщичества. Преобладающее влияние движимого имущества повсеместно ведёт, наоборот, к снятию бремени обеспечения литургических потребностей с его обладателей и к возникновению систем, обеспечивающих необходимые общности услуги и средства за счёт масс. Так, в Риме на место литургической, классифицированной в зависимости от уровня благосостояния и основанной на самовооружении воинской обязанности состоятельных граждан пришли фактическая свобода военной службы для граждан всаднического ценза и находящаяся на государственном обеспечении армия пролетариев, в других местах - наёмная армия, расходы на которую покрывались за счёт массового налогообложения. Вместо привлечения средств для покрытия внеочередных потребностей с помощью налога на имущество или принудительных беспроцентных заимствований, то есть литургического использования возможностей имущих для целей общности, в Средние века повсеместно распространилось покрытие расходов за счёт займов под проценты, залога земли, таможенных и других сборов, то есть получалось так, что срочные хозяйственные потребности общности при посредстве имущих слоёв превращались в источник прибыли или ренты; иногда (как одно время в Генуе) это приобретало характер управления городом и его налоговыми возможностями в интересах кредиторов государства. 
И наконец, усиливающийся вместе с ростом политически обусловленной потребности в деньгах поиск капитала со стороны различных сил, конкурирующих за власть и удовлетворяющих свои потребности за счёт денежного хозяйства, привёл в начале Нового времени к примечательному союзу между формирующими государства силами и привлечёнными ими привилегированными капиталистами, что сыграло важнейшую роль при зарождении современного капиталистического развития. Политика той эпохи по праву носит имя меркантилистской. Хотя, как мы видели, меркантилизм в смысле предоставления поддержки и привилегий движимому имуществу существовал везде и всегда, существует и сегодня там, где несколько самостоятельных принудительных образований находятся друг подле друга и конкурируют за счёт налогового потенциала и кредитных возможностей капитала своих сочленов, что присуще как Античности, так и Новому времени. Однако в начале Нового времени этот меркантилизм принял специфический облик и оказал специфическое воздействие, что произошло отчасти в силу особенностей структуры господства конкурирующих политических образований и их хозяйства, на чём мы остановимся позже, а отчасти (и преимущественно) в силу иного характера зарождающегося тогда и понимаемого как современный - по отношению к античному — капитализма, особенно неизвестного в прошлом современного индустриального капитализма, которому любая долговременная привилегия более всего шла на пользу. Во всяком случае, с тех пор конкурентная борьба крупных, приблизительно равных по силе чисто политических образований определяет внешнюю сторону политической власти и является, как известно, одной из важнейших специфических движущих сил капиталистических привилегий, которые возникли именно тогда и в изменённой форме сохраняются по сей день. Ни торговая, ни финансовая политики современных государств, то есть наиболее связанные с центральными интересами современной формы хозяйства направления экономической политики, в их генезисе и протекании не могут быть поняты в отрыве от этой очень своеобразной политической ситуации конкуренции и равновесия в европейской системе государств последних пяти столетий той ситуации, которую ещё Л. фон Ранке в своей первой работе определил как всемирно-историческую особенность Европы ${ }^{21}$.

\section{Литература}

Вебер М. 2016. Хозяйство и общество: очерки понимающей социологии. Т. І. Социология. Пер. с нем. под ред. Л. Г. Ионина. М.: Изд. дом ВШЭ.

Ranke L. 1824. Geschichten der romanischen und germanischen Völker. 1494-1514. 1. Bd., 1. Aufl. Leipzig; Berlin: Dunker \& Humblot.

Weber Max. 1978. Economy and Society. An Outline of Interpretive Sociology. Berkeley; Los Angeles, CA: University of California Press.

Weber Max. 2001. Max Weber-Gesamtausgabe. Bd. I/22-1: Wirtschaft und Gesellschaft. Teilband 1: Gemeinschaften. Tübingen: Mohr Siebeck Verlag.

21 Ранке Леопольд (Ranke Leopold von; 1795-1886) - немецкий историк, ведущий представитель историзма и один из основоположников современной исторической науки. Первая крупная работа Ранке, на которую и ссылается Вебер: [Ranke 1824]. 


\section{NEW TRANSLATIONS}

\section{Max Weber}

\section{Economy and Society: An Outline of Interpretive Sociology. Organized Groups}

WEBER, Max

(1864-1920) - German

sociologist, philosopher, historian, and political economist.

Translated into Russian by L. G. Ionin

\section{Abstract}

This book presents the second volume of Max Weber's fundamental work Economy and Society, which has been translated into Russian for the first time. The second volume "Organized Groups" uncovers emerging and crystallizing structures of rationality governing how organized groups function during different periods in their history. Concepts such as households, oikos, and ethnic groups and political associations (including parties and state), are defined here.

The Journal of Economic Sociology publishes an excerpt from one of the chapters of the second volume "Organized Groups" - 'Economic Relationships of Organized Groups.' This chapter introduces economic action and economically active groups; it classifies organized groups according to their group structure and economic function. It also explains the concept of closed and open economic relationships. In conclusion, it analyzes five types of want satisfaction by economically active groups, resulting in the question of which of those types most closely corresponds to a rational capitalistic economy.

The translation is edited by Leonid Ionin. The chapter is published with the permission of HSE Publishing House.

Keywords: sociology; Max Weber; economy; society; economic relationships; organized groups; economic interest; want satisfaction; economically active groups.

\section{References}

Ranke L. (1824) Geschichten der romanischen und germanischen Völker. 1494-1514. 1. Bd., 1. Aufl., Leipzig; Berlin: Dunker \& Humblot (in German).

Weber M. (1978) Economy and Society. An Outline of Interpretive Sociology, Berkeley; Los Angeles, CA: University of California Press.

Weber M. (2001) Max Weber-Gesamtausgabe. Bd. I/22-1: Wirtschaft und Gesellschaft. Teilband 1: Gemeinschaften, Tübingen: Mohr Siebeck Verlag (in German).

Weber M. (2016) Hozyaystvo i obshchestvo: ocherki ponimayushchey sotsiologii [Economy and Society: An Outline of Interpretive Sociology]. Vol. 1. Sociology. (Russian translation by L. G. Ionin), Moscow: HSE Publishing House (in Russian).

Citation: Weber M. (2017) Hozyaystvo i obshchestvo: ocherki ponimayushchey sotsiologii. Obshchnosti. [Economy and Society: An Outline of Interpretive Sociology. Organized Groups (an excerpt)]. Journal of Economic Sociology = Ekonomicheskaya sotsiologiya, vol. 18, no 1, pp. 13-27. Available at https://ecsoc.hse. $\mathrm{ru} / 2017-18-1 . h t m l$ (in Russian). 


\section{B. Мохов}

\section{Управляя неопределённостью и стигмой: региональный рынок ритуальных услуг в этнографических заметках}

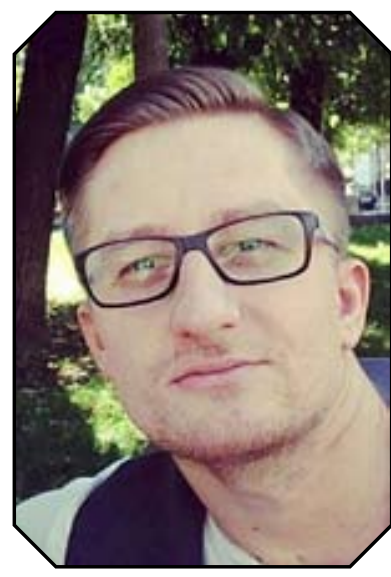

\section{МОХОВ Сергей}

\section{Викторович -}

аспирант школы социологических наук НИУ ВШЭ. Адрес: Россия, 10100, г. Москва, ул. Мясницкая, д. 20.

Email: svmohov.hse@ gmail.com
Борьба представителей западной похоронной индустрии с профессиональной стигматизацией привела к тому, что похоронный бизнес стал открытылм, публичнылм и сочиально ответственнылм. В то же время российский рынок ритуальных услуг по-прежнему окутан устрашающими мифами и негативныли стереотипами. Представители российской похоронной индустрии избегают любых форм публичности. Это приводит к открытой стигматизачии профессии. Почему сложилась подобная ситуащия? Можно ли предположить, что стигматизаџия поддерживается самим профессиональным сообществом?

На основе авторских этнографических заметок, собранных в полевом дневнике, в результате проводимого на протяжении года включённого наблюдения в одном из ичентральных регионов России, предпринимается попытка ответить на эти вопросы. Статья состоит из трёх частей. Вначале будут показаны распространённые модели похоронного рынка на примере таких стран, как США, Франциия и Швеция, и обозначены принциииальные отличия российской модели. Во второй части статьи автор описывает региональное ритуальное агентство и его владельца. Третья часть статьи характеризует рядовых работников рынка ритуальных услуг.

В качестве вывода предлагается следующее: российский рынок ритуальных услуг можно интерпретировать в терминах концепџии неопределённости Дэвида Старка. В фокусе регионального похоронного рынка неопределённость выражается в контролируемой дисфункииональности инфраструктуры, слабой и стихийной институционализачии и превалировании неформальных практик в поддержке связей сети. В дополнение к этому сама по себе профессиональная структура довольно закрыта для входа новых игроков и иерархизирована по криминальному принципу. Таким образом, сама структура ритуального рынка способна к эффрективному функиионированию только в случае сохранения статуса неопределённости. Это состояние поддерживается с помощьью контроля информачии, а стигматизация является инструментом сохранения профессиональной структуры.

Ключевые слова: рынок ритуальных услуг; похоронный бизнес; ритуальные агенты; антропология смерти; профессиональная стигматизация; похоронная индустрия.

Исследование проведено на средства Фонда поддержки социальных исследований «Хамовники» (проект 2016 008). 
Начиная с середины XX века представители западной похоронной индустрии ведут активную борьбу с профессиональной стигматизацией. С помощью рекламы, брендинга и агрессивных социальных кампаний ${ }^{2}$ они пытаются объяснить потребителям, что похоронное ремесло не только крайне необходимо обществу, но и абсолютно нормально [Thompson 1991; Cahill 1999; Carden 2001].

По мнению ряда исследователей, подобная дестигматизация имеет принципиальное значение для формирования всей современной западной похоронной индустрии [Seale 1998; Laderman 2005; Sanders 2009; Jalland 2006; Walter 2005]. Эта сфера бизнеса перестала вызывать отторжение и страх. В повседневном обороте такие слова с негативной коннотацией, как «могильщик» (undertaker), «гроб» (coffin), «труп» (the body), были заменены на нейтральные - «похоронный директор» (funeral director), «шкатулка» (casket), «покойный» (the deceased) [Thompson 1991; Laderman 2005]. Кроме того, отвечая на запрос на открытость и публичность, похоронная индустрия приобрела черты социально ответственного бизнеса. В Америке и Европе рынок ритуальных услуг проходит обязательное лицензирование, похоронные агенты получают необходимое образование и сдают тесты на профессиональную квалификацию, за их деятельностью следят специальные торговые и этические комиссии.

Российский рынок ритуальных услуг имеет ряд принципиальных отличий. Похоронный бизнес окутан устрашающими мифами и негативными стереотипами. Если спросить простого потребителя о том, что он знает про похоронную индустрию, то в ответе непременно пойдёт речь о коррупции, высоких ценах, хамском и циничном отношении ритуальных агентов и, конечно, о тотальной криминализованности данной сферы [Абелев, Рожков, Зульфугарзаде 2006; Елютина, Филиппова 2010; Барков, Грачёв 2013]. В оценках рынка ритуальных услуг преобладают негативные установки [Сильченко 2016].

Усиливает эти представления молчание со стороны самих работников рынка ритуальных услуг. В СМИ отсутствует любая информация о том, кто эти люди и как они живут. Работники похоронной сферы неохотно дают интервью, не участвуют в общественной и публичной жизни. Несмотря на то что рынок существует уже больше четверти века, о том, как он устроен, неизвестно практически ничего даже представителям экспертного сообщества и социальным исследователям. Доступ в поле для изучения закрыт [Филиппова 2009; Елютина, Филиппова 2010; Моисеева 2013].

Таким образом, фиксируется парадоксальная ситуация. С одной стороны, существуют общественный запрос на публичность ${ }^{3}$ и открытость данной сферы [Елютина, Филиппова 2010; Сильченко 2016], вполне успешный опыт работы западных коллег с подобным запросом. С другой стороны, сами представители российской похоронной индустрии никак не реагируют на это. Сообщество работников рынка ритуальных услуг остаётся довольно закрытой для внешних контактов структурой. Это приводит к открытой стигматизации, понимаемой прежде всего как поддержание превалирующих негативных стереотипов о профессии [Goffman 1963].

2 У. Томпсон указывает на несколько стратегий, которые позволяют говорить об управлении стигматизацией на примере американских и европейских похоронных агентств. Во-первых, это изменение языка, то, что сам Томпсон называет буквально символическим переопределением (symbolic redefinition). Во-вторых, дистанцирование от табуированных или неприятных тем с помощью, например, сдержанного юмора. В-третьих, профессионализм, то есть акцентирование внимания на владении определённым профессиональным знанием, таким как бальзамирование и знание ритуала. В-четвёртых, акцент на публичность, причём как в вопросах ценообразования, так и относительно устройства похоронного дома в частности [Thompson 1991].

3 Использованы данные закрытых фокус-групп, проводимых в рамках исследования рынка ритуальных услуг для ЗАО «Военно-мемориальная компания» в 2016 г. Однако такой же вывод можно сделать, если прибегнуть к поиску в СМИ по базе «Интегрум», по ключевым запросам: «рынок ритуальных услуг», «похоронный бизнес», «ритуальные агенты». Количество материалов и основная тематика посвящены тому, как устроен и работает рынок ритуальных услуг. 
Почему сложилась подобная ситуация? Почему стигматизация не встречает противодействия у самого профессионального сообщества? Какую функцию выполняют негативные стереотипы в структуре рынка ритуальных услуг? Цель данной статьи состоит в том, чтобы попытаться ответить на эти вопросы, опираясь на полевые материалы автора.

Статья состоит из трёх частей. Вначале будут охарактеризованы распространённые модели похоронного рынка на примере стран Европы и США, а также показаны принципиальные отличия российской модели, что позволит увидеть её специфические черты. Во второй части статьи речь пойдёт о региональном ритуальном агентстве и о функциях его владельца. При описании будут использованы полевые заметки. Наши наблюдения позволяют сделать вывод о неформальном характере сетевых связей при поддержании структуры рынка ритуальных услуг. В третьей части статьи я опишу его рядовых работников, что даст дополнительные представления о профессиональной структуре рынка. В заключении будет сделана попытка обобщить приведённые примеры и предложено объяснение того, какую именно функцию в сохранении структуры рынка ритуальных услуг выполняет стигматизация профессии.

\section{Методы}

Эмпирической базой данной статьи послужило проводимое полевое исследование в одном из центральных регионов Российской Федерации с суммарным населением один миллион человек. В ходе включённого наблюдения, которое является одним из основных методов изучения рынка ритуальных услуг [Suzuki 2002; Vélez-Zapata 2012], осуществлено описание и интерпретирована профессиональная деятельность одного из ритуальных агентств данного региона. Это небольшая по локальным меркам частная компания, проводящая не более 40 похорон в месяц (крупной считается компания, проводящая более 100 похорон в месяц). Агентство имеет четыре офиса в различных городах региона. В штате компании числятся не более 12 человек в зависимости от сезона и наличествующих заказов. Компания является семейным предприятием: руководят бизнесом отец и сын.

Моё участие в повседневной работе агентства сводится к следующему: во-первых, как рядовой член похоронной бригады я забираю тела умерших людей с места смерти, доставляю их в морг, копаю могилы, произвожу погрузку гроба и т. д. В этом случае наблюдение ведётся открыто для работников компании, которые знают о целях и задачах моего визита (я работаю над диссертационным исследованием), но закрыто для других участников интеракций, то есть для работников моргов, служащих кладбищ и др. (для них я остаюсь простым участником похоронной бригады). Во-вторых, я принимаю участие в работе агентства как консультант и партнёр владельца компании. Это является своего рода полевой легендой, используемой во время разнообразных встреч владельцев компании с конкурентами и другими деловыми партнёрами. В этом случае участники интеракций (например, представители местных администраций и других ритуальных компаний) не знают о том, кто я и какие цели преследую4.

В рамках полевой работы меня интересует прежде всего влияние инфраструктурных факторов на социальные интеракции, выраженные в текстах, и действиях ключевых акторов похоронного дела по отношению друг к другу [Мохов 2016]. Область рассматриваемых интеракций ограничена. Я рассматриваю только те действия, которые помогают осуществлять захоронение умершего (например, peшение проблемы получения тела в морге). Именно поэтому в фиксируемые ситуации попадают не только работники одного изучаемого агентства, но и другие, сторонние, акторы. Прежде всего, вышеупомянутые конкуренты, локальные акторы (работники моргов, кладбищ и т. д.), случайные участники похорон, члены других похоронных бригад, которые выполняют работы для нескольких агентств, родственники умерших и др. Это позволяет говорить об этнографии не только конкретного похоронного

4 Проблемы ограничения методологического инструментария, входа в поле, а также более подробная этнография ритуального агентства описаны в статье: [Мохов 2017]. 
агентства, но и всего регионального рынка ритуальных услуг с позиции включённого участника и наблюдателя ${ }^{5}$.

Включённое наблюдение началось в феврале 2016 г. и продолжается в период подготовки данной статьи. Время, проведённое в полевой работе, - свыше 60 дней. По этическим причинам и по договорённости с информантами я не могу называть точные географические локации. Все информанты и участники описываемых историй анонимизированы.

Помимо включённого наблюдения, проведено более 50 сессий этнографических интервью с более чем 30 участниками ритуального рынка. Этнографические интервью - это тематические разговоры с информантами (участниками ситуаций), которые проходят в рамках повседневных интеракций [Романов 1996]. Такие разговоры возникают зачастую спонтанно и имеют разную временную продолжительность. По форме такой разговор может быть диалогом и длиться более 1,5 часа, а может быть просто репликой по теме, короткой или даже минутной. В ходе этих разговоров не используются технические средства записи в силу серьёзных этических ограничений и требований к анонимизации информантов [Мохов 2017]. Именно поэтому нет возможности прямого цитирования интервью с информантами; приводится только переложение разговоров. Круг поднимаемых вопросов в подобных разговорах: личные биографии, взаимоотношения с коллегами, эмпатия по отношению к теме смерти, слухи и истории регионального рынка ритуальных услуг. Большинство участников этнографических интервью — мужчины среднего возраста (28-45 лет), со средним образованием, работающие в сфере более трёх лет.

В фокус исследования попали около 100 различных неформальных ситуаций, когда решались те или иные задачи, связанные с выполнением основной функции похоронного агентства, то есть с обеспечением захоронения умершего человека.

Все наблюдения и разговоры фиксируются в полевом дневнике, куда записывается всё, что было услышано, увидено, в чём довелось участвовать в течение того или иного дня наблюдений. Кроме того, ведётся быстрая запись в блокнот, который всегда с собой. Согласно Дж. ван Маанену, описания увиденных историй в полевом дневнике делятся на три основных типа [Van Maanen 1988]: (1) простые (realistic); (2) исповедальные (confessional), то есть отражающую рефлексию наблюдателя по поводу увиденного; (3) импрессионистические (impressionist), то есть связанные с методологическими проблемами и ограничениями использования полевого инструментария. Часть записей может быть отнесена к нескольким типам. Объём дневника и вспомогательного блокнота на момент подготовки статьи составляет более пяти авторских листов; количество записей — более 300.

\section{Похоронный бизнес: мировой опыт}

Похоронная индустрия является мультиинфраструктурным комплексом. Она всегда включает множество акторов с самыми разными связями между ними. Это приводит к широкой вариативности существующих моделей. Какой-то одной общей структуры или широко распространённой модели похоронного рынка не существует. Конфигурация агентов всегда зависит от экономического, культурного и исторического контекста [Walter 2005].

Западные исследователи, работающие с данной темой, предлагают первичную типологию похоронной индустрии, состоящую из двух уровней. Первый - это своего рода похоронная метаструктура, то, что называется индустрией, обслуживающей смерть и умирание («death care industry») [Smith 1996; Parsons 1999; Walter 2005]. Она включает всю систему инфраструктурных объектов, участвующих в за-

5 Судя по сообщениям и публикациям в тематических СМИ, данная модель регионального рынка может быть вполне успешно соотнесена с другими регионами Центральной России (кроме Москвы). 
хоронении, то есть катафальный транспорт, морги, кладбища, крематории, похоронные дома, производителей гробов и ритуальных принадлежностей, даже хосписы. Каждый из этих объектов занимается очень специфической деятельностью и не всегда напрямую связан с другими акторами. В каждой из этих областей существуют десятки различных специализаций - от водителей катафалков до траурных флористов [Parsons 1999; Walter 2005].

Степень и характер вовлечённости в сам фрейм похорон у таких специалистов достаточно разные. Если одни участвуют в проведении похорон напрямую, как, например, частные похоронные дома, то другие вовлечены косвенно. Например, компания может сдавать в аренду катафальный транспорт наравне с другими автомобилями. В США и Канаде лидером по продаже гробов являются компании Wal-Mart и Amazon - крупнейшие ритейлеры, которые продают товары самой разной направленности. Можно ли подобных акторов называть прямыми представителями рынка ритуальных услуг?

Второй уровень - это то, что называется funeral market (рынок ритуальных услуг) и funeral homes (похоронные бюро), то есть частные компании, напрямую занимающиеся продажей необходимых ритуальных принадлежностей и устраивающие прощальные церемонии. Это как раз те агенты похоронной сети, которые непосредственно сталкиваются со скорбящими родственниками и организуют саму процедуру погребения. Когда речь идёт о «похоронном рынке», в первую очередь имеют в виду именно их.

Границы первого и второго уровней подвижны, агенты обоих уровней связываются друг с другом всегда по-разному. То, как будет институционально выглядеть «типичное» ритуальное агентство и каковы его функции, зависит от нескольких факторов. Среди факторов, способных оказать влияние на сборку этих связей, - местное законодательство, которое меняет даже культурные нормы и практики. Например, в США нормативное предписание о необходимости похоронным домам иметь комнаты для бальзамирования приводит к локальному снижению уровня кремации (управляющие похоронными агентствами не имеют стимула продавать кремацию как услугу) [Harrington, Krynski 2002; Harrington 2007]. Или, например, отсутствие необходимого оборудования в больницах и моргах Франции привело к появлению специальных траурных залов в отдельных зданиях, оформленных как закрытые, приватные зоны, где выставляется гроб, - комнаты долгого прощания (chambres funéraires) [Blayac, Bougette, Montet 2012].

Тони Уолтер довольно наглядно продемонстрировал, как различия на уровне государственного регулирования похоронной инфраструктуры привели к формированию разных типов подобных связей агентов на обоих уровнях [Walter 2005]. Уолтер предлагает три институциональные модели рынка ритуальных услуг — это государственная; церковная; частная. Уолтер отмечает, что данные модели являются нормативными и возможно их смешение. Например, в таких странах, как США, вся похоронная инфраструктура принадлежит только частному бизнесу. Именно поэтому есть компании, владеющие кладбищами или крематориями, а в некоторых штатах — тем и тем [McChesney 1990]. Похоронные дома имеют свои морги, комнаты хранения тел, залы прощания, поэтому практически автономны от государства, которому принадлежат только крупные военные и мемориальные объекты.

В Скандинавских странах кладбища полностью находятся в ведении церкви, а услуги моргов оплачиваются государством. Похоронные компании поэтому нацелены на развитие сферы услуг и персонализации ритуала. Например, типичными услугами похоронного агентства являются заказ билетов на самолёт и поезд для родственников, приезжающих из других городов, поиск и бронирование гостиниц для гостей, встреча гостей в аэропорту, кейтеринг, то есть еда, которая доставляется в зал прощания в церковь, и логистика, организация онлайн-трансляции прощания [Bremborg 2006]. 
Во Франции до определённого времени похоронный бизнес находился практически полностью под контролем местных муниципалитетов, которые регулировали похоронную сферу, а также отвечали за содержание и развитие кладбищ [Trompette 2011; 2013]. В последние два десятилетия эта модель меняется в сторону частнособственнической.

Для Великобритании и некоторых стран Европы характерна смешанная модель, когда объекты похоронной инфраструктуры и находятся в ведении муниципалитетов, и принадлежат частному бизнесу. Например, крематории могут быть частными или принадлежать местным органам власти [Parsons 1999; Walter 2005; Jalland 2006].

\section{Российская модель рынка ритуальных услуг: четвёртый путь?}

Под какую из этих моделей подходит рынок ритуальных услуг в современной России? Каков характер связей агентов? Исходя из нормативного представления российский рынок ритуальных услуг, скорее, схож с французским типом, то есть похороны во многом остаются сферой ответственности государства. Согласно федеральному законодательству (Федеральный закон «О погребении и похоронном деле» от 12.01.1996 № 8-Ф3), вся похоронная инфраструктура принадлежит де-юре государству, а регулированием похоронной деятельности занимаются местные органы самоуправления. Под их юрисдикцию попадают организация содержания кладбищ, оказание услуг социальных похорон населению, регулирование деятельности частных ритуальных компаний и т. д. Согласно букве закона в России нельзя открывать частные кладбища, а возможность открытия морга сопровождается довольно серьёзными бюрократическими и технологическими проблемами. Так, частный морг не имеет права проводить вскрытия и выдавать заключения судебно-медицинской экспертизы, то есть, по сути, может работать только как трупохранилище. Это приводит к тому, что бизнес ритуальных компаний является агентским и посредническим по своему характеру, не обладающим собственной инфраструктурой [Мохов 2016].

Де-факто же в России отсутствует регулирование рынка ритуальных услуг со стороны государства. Это не раз отмечалось исследователями [Абелев, Рожков, Зульфугарзаде 2006; Елютина, Филиппова 2010; Барков, Грачёв 2013]. Так, местные органы самоуправления предпочитают снимать с себя ответственность и нагрузку на социальный бюджет, по сути, предоставляя рынку ритуальных услуг полную автономию.

Для снятия ответственности используются несколько стратегий. Во-первых, муниципальные кладбища не ставятся на кадастровый учёт; следовательно, их не существует как юридических объектов ${ }^{6}$. По всей России десятки тысяч неучтённых кладбищ. Отсутствие в кадастре означает, что отпадает необходимость заниматься их развитием и бюджетным финансированием [Мохов, Зотова 2017]. В ряде случаев работники муниципалитетов сдают «в аренду» кладбища ритуальным компаниям, неформально легализуя инфраструктурные потребности частного бизнеса. Например, во многих регионах есть так называемые частные кладбища, несмотря на то что законодательно такой формы частной собственности не существует [Почему на похороны... 2012]. В других случаях муниципальные кладбища оформляются по принципу государственно-частного партнёрства (ГЧП). Тогда кладбище продолжает номинально принадлежать муниципалитету, но всё бремя расходов по его содержанию несёт частная компания, которая конечно же стремится заработать, продавая места для захоронений, оказывая услуги по копанию могилы и т. д. ${ }^{7}$

6 Ознакомиться с материалами более чем нескольких тысяч судебных дел о необходимости постановки кладбищ на кадастровый учёт, возбуждённых прокуратурой к органам местного самоуправления, можно на сайте архива судебных актов [Судебные акты... 2017].

7 Что так же нелегально; см.: [Решение по судебному делу... 2012]. 
Во-вторых, благодаря серьёзным инфраструктурным ограничениям для входа частного бизнеса остаётся высоким уровень неформального включения других акторов в процесс организации и проведения похорон. Прежде всего, это касается работников «Скорой помощи», полиции, санитаров государственных моргов [Близится конец... 2014], работников местных муниципалитетов. Например, представители полиции и работники «Скорой помощи» продают информацию об умершем человеке ритуальным агентствам [Елютина, Филиппова 2010], а санитары моргов занимаются оказанием дополнительных ритуальных услуг — выдачей и подготовкой тела, омовением и т. д. [Мохов 2016].

Учитывая вышеизложенное, можно заключить следующее: рынок ритуальных услуг, несмотря на различные локальные конфигурации внутри нашей страны, включает не только частные ритуальные компании, но и множество других игроков. В качестве активных акторов рынка ритуальных услуг выступают работники моргов, санитары, полиция и многие другие участники теневых и неформальных экономических практик. Современный рынок ритуальных услуг в России представляет собой неформальную сеть держателей инфраструктурных ресурсов и частного бизнеса, что принципиально отличает его от западных моделей [Мохов 2016].

В России, по сути, отсутствует структурное деление на индустрию погребальных услуг (death care industry) и сам рынок ритуальных услуг (funeral market), как и разделение между государственным и частным сегментом этого бизнеса [Мохов 2016]. Именно поэтому границы профессиональной идентификации остаются в высшей степени подвижными. Так, держатели инфраструктурных ресурсов (санитары моргов, полиция, местные муниципалитеты) предпочитают публично не относить себя к этой сфере в силу теневых и нелегальных практик, несмотря на то что являются её активными участниками.

\section{Региональное ритуальное агентство: как это?}

Перед нами встаёт следующий логичный вопрос: а что есть вообще региональное ритуальное агентство? Каковы его функция и, самое главное, границы? Ответив на этот вопрос, мы получим возможность объяснить структурную функцию стигматизации. В этой части статьи, используя свои полевые заметки, я попытаюсь дать обобщённый портрет регионального ритуального агентства.

В современной России не существует никаких специальных требований к созданию частной ритуальной компании [Барков, Грачёв 2013]. Нет специальных надзирающих над этой сферой деятельности и регламентирующих её органов ${ }^{8}$. Компанию может открыть кто угодно, независимо от наличия специального образования и без лицензий. Это приводит к тому, что подавляющее большинство частных ритуальных компаний имеют юридическую форму ИП (индивидуальный предприниматель), пользуются упрощённым налогообложением или же не зарегистрированы вовсе.

При этом сама мультифункциональность сферы приводит к тому, что разные виды деятельности агентства должны подпадать под разное налогообложение. Например, ритуальными компаниями обычно используется налогообложение по схеме ЕВНД (единый налог на вменённый доход), как на «бытовые услуги». Но продажа ритуальных принадлежностей должна уже подпадать под налогообложение розничной торговли. Однако по факту никакого разделения не делается, и никто его не проверяет.

8 Необходимо сделать оговорку: подавляющее большинство нарушений в сфере ритуальных услуг попадает под административную ответственность. По признанию одного из информантов, полиция и прокуратура не занимаются подобными нарушениями. Ещё одной причиной «политики невмешательства» является саботаж со стороны ритуальных агентств: в случае проверок ритуальные агентства просто перестают выполнять свою работу, что приводит к недовольству родственников умерших людей и создаёт социальную напряжённость. 
Сегодня попросил прокомментировать А. и И. историю с налогообложением. Они ульюнулись и пояснили, что на это вообще всем начхать. Типа если и сдают куда-то какие-то докуменmы, то проверяющим органам это вообще всё без разницы <... Сам ЕВНД в итоге копеечный, учёта продажи гробов, венков и т. д. никто не ведёт. С их слов, налоговики и проч. не видят вообще никаких различий между продажей гроба и оказанием услуги по перевозки тела, например. В представлении А. и И., всё, что связано с похоронами, даже продажа убогих венков, это и есть «оказание ритуальных услуг». Задумался (из полевого дневника исследователя, ноябрь 2016).

Существует несколько основных коллизий нормативного характера, которые позволяют ритуальным агентствам находиться полностью в тени. В России, как уже говорилось, большинство муниципальных кладбищ находятся вне кадастра, то есть как юридических объектов их не существует. На тех же кладбищах, что есть в кадастровом плане, зачастую обнаруживается множество проблем, связанных с планировкой и распределением мест захоронений [Мохов, Зотова 2017]. Иными словами, в России нет единой системы статистики и учёта того, кто и где захоронен, и нет органов и структур, отвечающих за функционирование кладбищ (де-юре эту ответственность должны нести муниципалитеты). Ни одна структура в России не даст ответы на вопросы о том, сколько кладбищ существует на территории страны, сколько на них захоронено людей и, самое главное, кто именно.

Система учёта отсутствует даже при процедуре выдачи тела из морга. Согласно требованиям закона, выдать тело могут только родственнику или ответственному лицу. При этом не установлено, кто и каким образом должен определять родственные отношения между покойным и тем, кто пришёл забирать тело. По факту забрать тело из морга может кто угодно, предъявив обычный паспорт [Выдача свидетельств... 2014].

Таким образом, государство не требует предоставлять информацию о том, что происходит с телом умершего гражданина, куда и кто его везёт, где происходит захоронение. Отсутствие соответствующей системы государственной статистики позволяет ритуальным компаниям не вести собственный учёт и не иметь такого рода отчётности. Не существует никаких инструментов проверки того, сколько захоронений проводит конкретное ритуальное агентство.

Сегодня усльшиал любопытные ичифры. Там, в цеентре (В региональной столице. - С. М.), начались проверки по загсам, моргам и т. д. Всё после истории с судебкой < .. $>$ Приехал ФАС из Москвы и начал всех проверять. СИ сообщил, что, по официальным цифррам, в регионе в год умирает около 5000 чел. Так вот ФАС и прокуратура спрашивают: «А почему ваши ритуальные компании сдают отчётность о проведении ими 500 похорон? Кто остальные похороны проводит?» Те отбрехались, что «москвичи приезжают и хоронят, конкуренцию создают». Как обычно, спасает апелляция к москвичам (из полевого дневника исследователя, сентябрь 2016).

Сегодня вообще дичь какая-то случилась. Звонила бабка на телефон И. и просила, чтобы он ей помог найти её деда. И. долго не мог понять, при чём тут он и её мёртвый дед, потому что похороны не у него заказывались. Типа какие к нему вообще вопросы? < ... > А суть такая: дед умер, бабка захотела его кремировать, а крематорий в 100 км отсюда. Бабка попросила кремировать деда без неё, а прах привезти ей. Деда забрали и увезли. Уже прошла неделя, праха всё нет. Она звонит в крематорий, а там не в курсе про такого клиента вообще. Мол, никакого деда не привозили, фамилии такой нет. Бабка говорит, что нашла телефон И., кто-то порекомендовал, и вот она просит помочь найти тело. Название ритуалки, забравщей тело, 
конечно, не помнит, чеков нет. Чем закончилось, не понятно. Больше не звонила (из полевого дневника исследователя, июль 2016).

Подобная коллизия, вызванная отсутствием отчётности, приводит к тому, что многие ритуальные компании даже не регистрируются как юридическое лицо. Как правило, подобная теневая форма оказания ритуальных услуг распространена в сельских регионах, где по институциональной инерции, ещё со времён СССР, похоронной деятельностью граждане продолжают заниматься самостоятельно, без обращения в районный центр и т. д. [Филиппова 2009]. Ритуальные «компании» в таком случае осуществляют весь цикл похорон, то есть транспортируют тело в морг (если он есть), предоставляют транспорт, продают ритуальные принадлежности, подготавливают место захоронения.

Сегодня в Д. (Небольшой город, где находится один из офисов компании, численность около 8000 жителей. - С. М.) опять показательная история с А. <..> Вообще А. - интересный персонаж. У него даже офиса нет; встречается с клиентами у старого фонтана, мне кажется, вообще единственной тут культурной достопримечательности после местного магазина «Дикси». Все свои венки хранит в гараже или прямо в машине - стареньком «Соболе». Катафалк у него колоритный - георгиевские ленточки, внутри шикарный ковёр. Не понимаю, как в нём вообще можно кого-то возить. Чувствую себя Б. Малиновским, наблюдающим за аборигенами <... Рсли А. вдруг нужен гроб, то он возит клиентов в М., и они там вместе покупают всё, что нужно. Иногда какие-то гробы делают сами, в гараже у него лежат. Самих клиентов ему поставляет местный священник отец $C$., с которым у них какая-то особая форма картеля. В храме никого не отпевают, кроме своих клиентов. В дополнение к этому A. продаёт места на местном кладбище, осуществляет подготовку места захоронения роет могиль, ограды ставит и т. д. Самое крутое то, что А. все тут знают как директора кладбища. Говорил с местными, они мне: «Без А. никак нельзя похорониться, он кладбищем заведует». Спрашиваю: «А кто его назначил туда?». Отвечают: "Дык он сам». Вообще, конечно, поразительная правовая безграмотность. Как я понял, его фирма существует уже больше 10 лет благодаря родственным связям с чиновницей из местной администрации. Эта чиновница и клиентов тоже ему поставляет. Когда родственники приходят оформлять свидетельство о смерти или просить о предоставлении места для захоронения, она им сразу советует обратиться к А.: «Он же директор кладбища». Помимо самого А., в фирме работают ещё два человека, которые составляют похоронную бригаду. Названия у них никакого нет. < .. > Вообще хорочо, что он хотя бы тела у себя не хранит, как в М., где трупь на ночь в машине оставляют. Надо узнать про А. побольше и попытаться у него что-нибудь купить (из полевого дневника исследователя, июль 2016).

В больших городах ритуальные фирмы всё же имеют первичные признаки юридической организации частного бизнеса. Однако теневой характер похоронной сферы приводит к тому, что, как правило, официально в штате числится только учредитель и в крайних случаях ещё несколько человек. Остальные акторы ритуального рынка работают без официального трудоустройства, заработная плата им выплачивается сдельно в зависимости от выполненных работ: например, за каждые обслуженные похороны или за каждую выкопанную могилу.

Наблюдения в ходе полевой работы позволяют сделать вывод, что в большинстве случаев ритуальные компании делятся на два больших блока: (1) те, кто занимается похоронами (РПУ — ритуальнопохоронные услуги), и (2) те, кто занимается установкой и продажей мемориальных сооружений и памятников. Как правило, два вида похоронного бизнеса бывают соединены вместе довольно редко. 
В этом плане РПУ гораздо прибыльнее бизнеса по установке памятников по нескольким причинам. Во-первых, сезонность: памятники можно ставить только в хорошую погоду, с весны по раннюю осень, зимой заказы отсутствуют. Во-вторых, организация похорон - это бизнес на услугах; не нужно ничего производить и нести ответственность за качество продукта. Именно поэтому установка памятников считается гораздо менее прибыльной и престижной частью похоронного бизнеса.

Вся выручка чаще всего проходит только первичную бухгалтерию, то есть производятся общий учёт поступивших средств и их дальнейшее распределение между агентами сети. Несмотря на потенциально высокий уровень маржинальности бизнеса в сфере услуг, большинство аккумулируемых средств уходит на поддержание самих неформальных связей сети.

Интересные иифры сегодня усльшмал. Надо будет сравнить с американскими цифрами и в Англии. Смысл такой: средняя цена похорон - около 50-60 тыс. руб. Агентство К. делает около 100-110 похорон в месячу. Следовательно, в месяџ имеет около 6 млн руб. выручки. При этом около 3,5 млн руб. уходит на оплату сливов (Получение информации о случаях смерти. - С. М.), решение проблем с участковыми, полицией, администрачиями и т. д. Занимательная арифметика. Агентство работает на поддержание сети. Надо будет ещё достать информаџии по ичифрам (из полевого дневника исследователя, декабрь 2016) ${ }^{9}$.

Несмотря на распространённое убеждение, что похоронный бизнес является сверхприбыльным, для региональных формаций ритуального рынка этот тезис не совсем справедлив. Как правило, ритуальное агентство по уровню доходов владельца сопоставимо со средним бизнесом, то есть с кафе, ресторанами, ремонтными мастерскими. В месяц владелец ритуального агентства в регионе получает 50-150 тыс. руб. в зависимости от размера агентства, что, конечно же, сильно выделяет его в сравнении с зарплатами наёмных рабочих ${ }^{10}$.

Никак не пойму, сколько получают в итоге ритуальщики, то есть сами владельцьы. Например, тот же К. Кучу денег тратит на обслуживание своей неформальной сети. Машина у него недорогая, джип-корееи, 3-5-летний. Живёт в квартире, а не в загородном доме. Знаю, что пьёт постоянно по клубам и ресторанам. Пьттаюсь прикинуть средний доход исходя из уже известных иифр. Думаю, что не очень высокий, на уровне хорошей средней зарплаты в Москве. Деньги тратятся, правда, как-то странно. Ситуаџия типичная, судя по наблюдениям за другими директорами. У В. ещё ресторан свой. Он в разговоре с И. сказал, что ресторан прибыльнее и с ним меньше проблем, ритуалка его достала (из полевого дневника исследователя, октябрь 2016).

Однако по сравнению с другими представителями частного бизнеса владелец ритуального агентства имеет ряд конкурентных преимуществ. Главное из них - отсутствие закреплённой юридической формации и определённая стихийность институционализации: ритуальный бизнес нельзя купить, и нельзя выполнить его рейдерский захват. В дополнение к этому в изучаемом регионе большинство похоронных компаний имеют в названии слово «ритуал» (или название вообще состоит только из этого слова); в отдельных случаях содержится и указание на принадлежность к государственным структурам (например, «городская похоронная служба»). Подобная мимикрия позволяет самоопределяться агентствам как представителям городской службы, а также избегать негативной идентификации.

9 Подобные приблизительные расчёты можно провести и самостоятельно. Средняя цена похорон в регионе для больших агентств - около 60 тыс. руб. Количество похорон - 120 в месяц. При этом оплата услуг информаторов обходится приблизительно в 15 тыс. руб., к этой сумме прибавляется оплата услуг морга -20 тыс. руб.

10 Средняя зарплата в изучаемом регионе составляет 35 тыс. руб. 
Как итог: региональное ритуальное агентство представляет собой, скорее, симбиотическую экономикохозяйственную формацию, а не оформленный бизнес-процесс. Этот бизнес системно не регулируется и не контролируется государством и надзорными органами; он может быть официально не зарегистрирован, не вести систему учёта и статистики; даже в случае официальной регистрации его работники осуществляют свою деятельность в теневом секторе экономики и не привязаны к конкретным компаниям. Само ритуальное агентство имеет одного ключевого работника — директора.

\section{Владелец ритуального агентства — кто он?}

Организовать или открыть человеку со стороны собственную компанию в сфере ритуальных услуг практически невозможно. Для входа в этот бизнес существует несколько труднопреодолимых барьеров. Прежде всего, речь идёт о необходимости налаживания контактов для получения заказов. Как уже отмечалось выше, для этого нужно обладать неформальными связями на одном из существующих инфраструктурных объектов - в морге, на кладбище или при транспортировке тела; иметь того, кто будет предоставлять информацию компании об умерших [Мохов 2016]. В каждом морге должны оплачиваться установленные таксы, а на каждом кладбище - соблюдаться принципы копки могилы (например, на одном погосте нельзя копать никому, кроме конкретной бригады, обслуживающей данный объект, в то время как на другом - можно).

В изучаемом регионе случилась неприятная история, которая иллюстрирует это утверждение.

У К. резкий обвал клиентов. Парни из бригад жалуются, что похорон сейчас почти нет. А история трагичная и показательная одновременно. Ему все сливы делала дама со станции «Скорой помощи». Сливала много и постоянно; там целая агентурная сеть. Так вот у неё случилось горе - выпала из окна дома её дочь, разбилась насмерть. Она решила, что это наказание высших сил за все похоронные грехи. Мол, Бог наказал за то, что торговала мёртвыми. Устроила истерику, сливать прекратила. Интересно, как быстро К. заткнёт пробоину в своей инфраструктурной сети? (из полевого дневника исследователя, ноябрь 2016)

Полностью неформальный характер бизнеса исключает и появление крупных федеральных игроков ${ }^{11}$ : для того чтобы ритуальная компания успешно функционировала, необходимо поддерживать неформальные связи во всей сети. Существуют монополисты в этой сфере, например ГБУ «Ритуал» Москвы. Но они функционируют только в конкретном регионе, в то время как в Европе, Америке, Канаде и Австралии существуют национальные похоронные корпорации, такие как SCI (Service Corporation International) в Америке, Австралии, Германии или PFG (Pompes Funèbres Générales) во Франции.

Директор ритуального агентства - это всегда тот, кто налаживает и поддерживает все неформальные связи сети. Стандартная история открытия ритуальной компании в таком контексте выглядит следующим образом: есть родственник или близкий человек, который имеет доступ к инфраструктуре моргу или кладбищу. Этот человек может оперативно делиться информацией об умершем или берёт на себя функцию решения возникающих проблем. В таком случае открывается ритуальная компания, главная цель которой состоит в агентской связи всей инфраструктурной цепочки [Мохов 2016].

11 В одном из частных исследований, проводимых мною для крупной федеральной компании, которая показывает убыток на протяжении последних семи лет, было установлено, что федеральная компания подобного рода не может работать в теневом секторе, где присутствует огромное количество игроков с разными понятиями о стоимости услуг. Например, в одном морге просят 10 тыс. руб. за услуги по омовению тела, в другом - 15 тыс. руб. Подобная компания не может проводить похороны и все сопутствующие расходы без официального учёта, поэтому региональные представительства компании показывают убыток, предпочитая оставлять все похоронные услуги в теневом секторе экономики. 
Зачастую ритуальные компании могут открывать и санитары морга. Например, подобный бизнес был организован санитаркой морга, которая имела возможность прямо на месте предлогать ритуальные услуги родственникам умерших.

Про Л. надо говорить, конечно, отдельно. Очень предприимчивая <... Ей около 55 лет, несколько детей. Всю жизнь работает санитаркой в морге. Выписывает и отдаёт все необходимые бумажки, распределяет, кому и когда выдавать тело. Берёт плату за всё те же непонятные услуги морга < .. > Круто, что у неё при этом есть ещё и своя ритуальная фирма. Раньше просто продавала гроб, венок, убранство прямо тут, в морге, а недавно сняла офис. Отсылает клиентов туда. Легко берёт в аренду катафалки у ритуальщиков; никто с ней ссориться не хочет. Так же, если нужно, гробик недостающий и т. д. Оборот у неё небольшой, делает около трёх-четырёх похорон в месяи. Клиенты - сельские жители, которых ещё не успели перехватить другие. В разговоре с СИ, когда забирали тело, жаловалась, что не хватает денег на ремонт её третьей квартиры. По-моему, работники государственных инфраструктур больше всего получают с ритуалки (из полевого дневника исследователя, май 2016).

Именно поэтому в ритуальный бизнес не приходят со стороны. Любой новый игрок имеет привязку к старому агенту локального ритуального рынка; это может быть представитель местной администрации, полиции, «Скорой помощи», или же сам игрок оказывается таким инфраструктурным «держателем». В отдельных случаях новый игрок имеет привязку к другой ритуальной компании.

Такая привязка является своего рода карьерным ростом для любого работника сферы ритуальных услуг. Придя в бизнес работать простым членом похоронной бригады, спустя время, завязав знакомства с другими участниками рынка и получив необходимые связи на инфраструктурных точках, такой работник пробует открыть собственное ритуальное агентство.

Сегодня Г. рассказал, как А. пытался свою ритуалку открыть. Поработал год здесь (В местной компании. - С. М.), со всеми познакомился, обзавёлся связями, снял гараж и нашёл машину для перевозки. Начали работать; причём вполне успешно. Даже катафалк купили. Через полгода закрылись. Сгубила жадность. Стали обманывать информатора, который сливы делал. Получил чёрную метку (из полевого дневника исследователя, июль 2016).

Как было показано, владелец ритуального агентства - это ключевая фигура, вокруг которой выстраивается вся сеть. Стать владельцем ритуального агентства можно благодаря личному знакомству с ключевыми участниками и представителями инфраструктурной цепочки похорон или с помощью карьерного роста, то есть выйдя из рядового члена похоронной бригады, а также обзаведясь обозначенными выше связями.

\section{Персональные биографии работников рынка ритуальных услуг}

До этого места повествование выстраивалось вокруг общих характеристик структуры провинциального рынка ритуальных услуг. Были продемонстрированы принципиальные отличия отечественных моделей похоронной индустрии от мировых, а также показана специфика теневых связей агентов похоронной сети в современной России. Перед тем как приступить к интерпретации функции стигматизации, логично было бы попытаться очертить траектории биографии работников рынка ритуальных услуг, ответив на вопросы о том, кто эти люди, что создают и как поддерживают структуру. И главное, почему занимаются этим видом услуг. 
В один из дней, ведя наблюдение за работой ритуального агентства, я спросил у владельца компании: «Что ты можешь рассказать об HR-политике ${ }^{12}$ собственного агентства?». На что получил ответ, иллюстрирующий в данном контексте очень многое: «Ну, смотри, просто Коля сидел вместе с Валерой, а Валера вроде как сидел с Виталиком. Вот и вся твоя HR-политика».

По наблюдениям, большинство работников рынка ритуальных услуг имеют судимости за самые разные преступления. Среди основных уголовных статей превалируют мелкие нарушения - кражи, воровство, хулиганство. Наличие криминального прошлого подталкивает к работе в данной сфере, так как после погашения судимости многие бывшие заключённые испытывают определённые проблемы с официальным трудоустройством. В то же время на рынке ритуальных услуг отсутствие стажа работы и криминальное прошлое не имеют никакого негативного влияния на получение места и дальнейшую карьеру. По признанию информантов, многие работники в данном бизнесе оказались по приглашению знакомых: однажды кто-то из друзей попросил помочь и подменить заболевшего напарника в похоронной бригаде.

В одном из случаев работник похоронной бригады Валерий является лучшим другом могильщика Ивана. Они имеют очень схожие биографии: выросли в одном городском районе, учились в одной школе, имеют судимости. У Валерия - судимости за воровство и хулиганство, а Иван судим за мошенничество в начале 1990-х гг. При этом, по собственному утверждению Ивана, судимость является результатом конкурентной борьбы: в прошлом Иван был владельцем крупной строительной и риэлторской компании. У Валерия трое сыновей, двое из которых тоже работают в ритуальном бизнесе. Валерий и Иван знакомы 45 лет; они так шутят по поводу своей биографии: «В детстве в одной песочнице лопатками ковырялись, так и сейчас вместе ковыряем лопатами землю».

Испьтывьюю чувство огромной эмпатии к ребятам. Вспоминаю Варлама Шаламова. Такое ощущение, что это прошлое (Криминальное. - С. М.), которого было не избежать. С одной стороны, у всех судимости, но они никаким образом не проявляются. Воспитанные люди, поставленная речь. Выдают только татуировки, пожалуй (из полевого дневника исследователя, декабрь 2016).

Положение в криминальной иерархии переносится и на структуру рынка ритуальных услуг.

Институциональный парадокс конечно: агентство В., а оно довольно крупное, руководится К. Ему всего 25 лет, он - сын криминального авторитета (по крайней мере, так себя позиционирует). Все испытывают страх перед ним и предпочитают не вступать с ним в открытый конфликт. Как говорят, его отеи - серьёзный человек с серьёзным прошлылм. Как удалось выяснить, никто точно не знает ни уголовной статьи, ни деталей его персональной биографии, но его криминальное прошлое постоянно вспльвает в разговорах как важный символический капитал (из полевого дневника исследователя, июль 2016).

Криминальное прошлое работников рынка ритуальных услуг позволяет иерархизировать структуру. Высокий статус в криминальном сообществе является признаком того, что человек решителен и опасен. Это позволяет расценивать его как обладающего высоким потенциалом для поддержания неформальных связей сети. Судимость, с одной стороны, возводит её носителя в ранг неблагополучных граждан, а с другой - наделяет его сакральным статусом внутри сообщества. Криминальное прошлое в определённой степени оказывает влияние на формирование самого профессионального сообщества, помимо иерархизации создаёт символическую структуру, основанную на представлении о физическом насилии как одном из способов решения конфликтов. При этом в бизнесе высок уровень участия бывших работников полиции, которые тоже обеспечивают ресурсную поддержку сети.

12 Human Resource (англ.) — человеческие ресурсы. 
Однако я должен отметить, что сама «криминализированность» сферы - конструируемое представление. Проявления структурной мафии или организованных преступных групп мною замечены не были. Речь, пожалуй, идёт о двух типах сообществ: (1) люди с криминальным прошлым, осуждённые по лёгким и средним статьям, отчасти романтизируют преступность и переносят на профессию свои нормативные представления, а также (2) симбиотические формации представителей власти с людьми с криминальным прошлым.

Была тут на днях разборка. Очень комично выглядит. Сначала друг у друга выяснили, «кто под кем ходит». Так понимаю, это своего рода ритуал, не имеющий к реальности никакого отношения. СИ сказал, что работает с Йосей Либерманом. Конкуренты признали, что про Либермана сльшали, вопросов нет. Спросил у СИ, кто такой Либерман. Ответил, что не знает, когда-то хоронили мужика и запомнились имя с фамилией. Постмодерн (из полевого дневника исследователя, май 2016).

Как отмечалось ранее, у работников рынка ритуальных услуг отсутствует то, что можно назвать лояльностью в отношении конкретных компаний. Это выглядит вполне оправданно, если учесть отсутствие полноценных брендированных фирм и стихийный характер бизнеса. Участники похоронных бригад не работают исключительно в одном ритуальном агентстве, а могут выполнять заказы для разных компаний. Работники локального рынка ритуальных услуг не просто всегда знакомы друг с другом и составляют одно профессиональное сообщество, но и обязательно являются бывшими «сослуживцами». Фактически каждый из значимых акторов, присутствующих в бизнесе какое-то определённое время, работал ранее в других ритуальных фирмах и постоянно поддерживает связи с участниками рынка.

По признанию информантов, среди ближайших родственников не существует единого мнения насчёт рабочей специализации информантов. Зачастую члены семей работников рынка ритуальных услуг сами приходят в данный бизнес, поэтому с годами образуются целые семьи, которые поколениями занимаются этими услугами. Например, мать семейства работает в местной администрации и предоставляет информацию о новых случаях смерти, а отец, по факту, выполняет роль ритуального агента, сын администрирует работу похоронной бригады. В другом случае семейная пара работает в ритуальном агентстве в качестве рядового грузчика похоронной бригады и продавца ритуальных принадлежностей.

Таким образом, можно заключить, что профессиональное сообщество работников рынка ритуальных услуг - довольно закрытая и саморегулируемая структура. Попадают в профессию по личной рекомендации или по приглашению, работники имеют схожие биографии, объединённые нередко криминальным прошлым. Всё это формирует двойную стигматизацию профессии — как человека, связанного с «грязной работой» (трупами), и как человека, имеющего судимость.

Представив краткое этнографическое описание рынка ритуальных услуг и его работников, попытаемся объяснить функцию стигматизации профессионального сообщества.

\section{Неопределённость, информация и стигма в структуре рынка ритуальных услуг}

Из представленного описания регионального рынка ритуальных услуг становится очевидным его ключевое отличие от западных моделей, несмотря на их широкую вариативность. Первым серьёзным отличием является стихийная организационная структура и слабая институционализированность похоронных бизнес-процессов. По сути, региональное ритуальное агентство - это не частная бизнескомпания, а формация самых разнообразных акторов вокруг конкретных инфраструктурных объектов [Мохов 2016; 2017]. Само функционирование этой системы возможно только благодаря налаженным сетевым связям и состоянию неопределённости [Stark 2009], свойственному этому рынку. Неопреде- 
лённость рынка ритуальных услуг иллюстрируется примерами торга на инфраструктурных объектах, когда не существует единых цен для одних и тех же услуг и единого и (или) открытого доступа к ним, наличествуют элементы саботажа, а организация конкретных похорон складывается всегда ситуативно. Неопределённость в этом фокусе является главной характерной чертой рынка ритуальных услуг и условием его стабильности. Неопределённость заключается, во-первых, в уже отмеченной слабой институционализации, а во-вторых, в подвижном статусе самих связей сети.

Согласно Старку, предпринимательство на основе неопределённости намеренно поддерживает различные типы оценивания ситуации, превращая конфликты оценивания между акторами в ресурс [Stark 2009]. Как отмечает Старк, предприниматель отличается в этом контексте от посредника, потому что он не просто заполняет разрывы между акторами сети, а управляет ими. В случае регионального рынка ритуальных услуг управление неопределённостью заключается в намеренной дисфункциональности инфраструктурной сети [Мохов 2016].

Состояние неопределённости, как подчёркивает Старк, поддерживается благодаря искажению информации о работе структуры рынка. Набор устоявшихся утверждений (знание правил игры) о рынке ритуальных услуг и есть подобная информация. Режимы управления такой информацией позволяют связать неопределённость и стигматизацию.

Какой информацией управляет рынок ритуальных услуг и как? Джордж Ритцер приводит три критерия, согласно которым какая-либо деятельность может рассматриваться как девиантная или стигматизируемая: если она (a) является незаконной; (b) считается аморальной и (c) считается неприличной [Ritzer 1977]. При таком фокусе рассмотрения, который предлагает Ритцер, управление доступом к похоронной инфраструктуре (ограничение информации о её работе) и есть стратегия стигматизации. Например, угрозы родственникам выдать тело из морга в неподобающем виде являются аморальным и неприличным актом, но позволяют получать прибыль. Отсутствие информации о ценообразовании на ритуальные принадлежности (сколько стоит гроб?) - тоже инструмент ограничения и одновременно стигматизация. Практики распределения мест на кладбище и неприличны, и незаконны, а значит, и стигматизируемы, но именно они и составляют неопределённость [Мохов, Зотова 2017]. Рынок ритуальных услуг, по сути, становится «чёрным ящиком» в глазах потребителя. Сам же этот рынок подвержен негативной мифологизации. Подобная негативная стереотипизация и делает структуру устойчивой.

Таким образом, рынок ритуальных услуг функционирует только в состоянии неопределённости, как её понимает Старк, когда отсутствует любая информация об инфраструктурной функциональности - об услугах, стоимости, возможностях, правилах игры. Эта неопределённость достигается путём реализации нескольких информационных стратегий, главная из которых - стигматизация.

Профессиональная структура рынка ритуальных услуг только усиливает стратегию стигматизации. Как было показано, работники похоронной сферы имеют схожие биографии: судимы, происходят из одного социального круга, зачастую знакомы друг с другом ещё до начала работы в данной области. Криминальное прошлое (или принадлежность к силовым структурам) оказывает влияние на характер взаимоотношений между агентами сети. Криминальные понятия переносятся на повседневную жизнь [Олейник 2001]. Вход в профессию довольно ограничен и предполагает наличие устоявшихся связей и рекомендаций. Таким образом, профессиональная структура обособленна и довольно закрыта.

Сам бизнес является не столь прибыльным, как принято думать, в силу того, что большая часть выручки расходуется на поддержание похоронной агентской сети, а неформальный характер взаимоотношений опасен тем, что любая компания может легко потерять источник получения заказов. Низкая маржинальность и неформальность приводят к достаточно высокому уровню конкуренции. 
Подобная организация рынка ритуальных услуг делает возможным его системное функционирование только при сохранении определённого равновесного состояния, которое достигается при стигматизации и поддержании негативных стереотипов о похоронной сфере, что помогает изолировать профессиональную структуру от любого агрессивного влияния извне. Работники рынка ритуальных услуг заинтересованы в сохранении мифов о мафиозном характере похоронной сферы и широко распространённом насилии.

\section{Вместо заключения}

На основе авторских этнографических заметок, собранных во время полевого исследования, была предпринята попытка описать структуру регионального рынка ритуальных услуг; дано возможное объяснение закрытости данной структуры и функции самостигматизации.

Было показано, что рынок ритуальных услуг имеет ряд отличительных особенностей: слабая и даже стихийная институционализация; превалирование теневых и неформальных практик; неопределённость, которая выражается не просто в разрывах между ключевыми акторами сети, а в локальной дисфункциональности инфраструктурных акторов.

Таким образом, структура ритуального рынка способна к эффективному функционированию только в случае сохранения статус-кво, который понимается как, во-первых, неформальный характер связей инфраструктурных игроков, а во-вторых, контролируемая конкуренция путём самоограничения профессионального сообщества. При таком фокусе рассмотрения стигматизация является инструментом сохранения статус-кво и самой структуры.

Каждая профессия пытается сформулировать и выработать круг вопросов, которые используются не просто как идентификационные черты профессии, но и как защитные механизмы. Рассмотренный в этом контексте процесс становления западной похоронной индустрии привёл к необходимости борьбы с профессиональной стигматизацией. Изменение культурной среды вызвало необходимость объяснения роли и функции похоронных домов в современном западном обществе [Laderman 2005]. Pocсийский же рынок ритуальных услуг пошёл по пути защиты сложившейся структуры, которая также требует сохранения статус-кво, но достигается не путём разъяснения, а через сокрытие информации об устройстве рынка, функционировании хозяйствующих субъектов, особенно в условиях, когда весь бизнес строится на неформальных связях.

Однако остаются непрояснёнными механизмы управления стигматизацией. В приведённых примерах и интерпретациях стигматизация выступает как сложившийся комплекс представлений, который поддерживается локально при столкновении с потребителем в ситуации покупки. Очевидно, что для дальнейшего подтверждения «управляемости» стигматизации стоит рассмотреть действия ритуальных компаний в разрезе конкурентной борьбы друг с другом. Например, проанализировать объединения в различные ассоциации, публично декларирующие цели борьбы с «чёрными агентами». Также остаётся не прояснённым вопрос о самоидентификации и о выстраиваемых границах профессии: как видят себя и профессию сами представители ритуального рынка (хотя бы работники похоронных бригад)?

Рынок ритуальных услуг в современной России остаётся неисследованным явлением. Хочется надеяться, что ряд поставленных в статье вопросов, а также предложенные ответы побудят исследователей обратить внимание на данный многогранный феномен. 


\section{Литература}

Абелев М., Рожков С., Зульфугарзаде Т. 2006. Похоронное дело в России. Заместитель главного врача. 4: $137-140$.

Барков А., Грачёв Р. 2013. Рынок ритуальных услуг: проблемы гражданско-правового регулирования. М.: Изд-во «Юрлитинформ».

Близится конец ритуальной подработки? 2012. Форум судебных медиков. URL: http:/www.sudmed.ru/ index.php?showtopic=23829 (дата обращения: 13.01.2017).

Выдача свидетельства о смерти «не-родственникам». 2014. Форум судебных медиков. URL: http://www. sudmed.ru/index.php?showtopic=18080 (дата обращения: 13.01.2017).

Елютина М., Филиппова С. 2010. Ритуальные похоронные практики: содержательные изменения. Соичологические исследования. 9: 86-94.

Моисеева Е. 2013. Твоя последняя покупка, выбранная кем-то другим. Экономическая соииология. 1 (14): 13-22. URL: https://ecsoc.hse.ru/2013-14-1.html (дата обращения: 17.01.2017).

Мохов С. 2016. Рынок ритуальных услуг в современной России: поломка похоронной инфраструктуры как властный ресурс. Социология власти. 28 (4): 83-104.

Мохов С. 2017. Рынок ритуальных услуг: опыт этнографии сенситивного поля. Телескоп: журнал соицологических и маркетинговых исследований. 1 (в печати).

Мохов С., Зотова В. 2017. Дело об ограде, столике и скамье: режимы справедливости в практиках распределения мест на кладбище. Журнал исследований соииальной политики (в печати). URL: https:// jsps.hse.ru/vpechati

Олейник А. 2001. Тюремная субкультура в России: от повседневной жизни до государственной власти. М.: Инфра-М.

Почему на похороны курянам приходится копить несколько лет? 2012. Аргументы и факты. Черноземье. URL: http://www.chr.aif.ru/society/history/183535 (дата обращения: 13.01.2017).

Решение по судебному делу. 2012. URL: http://lenobl.fas.gov.ru/solution/6952 (дата обращения: 13.01.2017).

Романов П. 1996. Процедуры, стратегии, подходы «социальной этнографии». Социологический журнал. 3-4: 138-148.

Сильченко Т. 2016. Рынок ритуальных услуг в оценках населения города Абакана. Психология, соииология и педагогика. 5. URL: http://psychology.snauka.ru/2016/05/6762 (дата обращения: 20.11.2016).

Судебные акты. 2017. URL: http://sudact.ru/regular (дата обращения: 13.01.2017).

Филиппова С. 2009. Кладбище как символическое пространство для социальной стратификации. Журнал социиологии и социиальной антропологии. 12 (4): 80-96. 
Blayac T., Bougette P., Montet C. 2012. How Consumer Information Curtails Market Power in the Funeral Industry. SSRN Electronic Journal. URL: http:/www.lameta.univ-montp1.fr/Documents/DR2012-12.pdf (дата обращения: 13.01.2017).

Bremborg A. 2006. Professionalization without Dead Bodies: The Case of Swedish Funeral Directors. Mortality. 11 (3): 270-285.

Cahill S. 1999. The Boundaries of Professionalization: The Case of North American Funeral Direction. Symbolic Interaction. 22 (2): 105-119.

Carden P. 2001. Rising from the Dead: Delimiting Stigma in the Australian Funeral Industry. Health Sociology Review. 10 (2): 79-87.

Goffman E. 1963. Stigma: Notes on the Management of Spoiled Identity. Englewood Cliffs, NJ: Prentice-Hall, Inc.

Harrington D. 2007. Markets Preserving Funeral Markets with Ready-to-Embalm Laws. The Journal of Economic Perspectives. 21 (4): 201-216.

Harrington D., Krynski K. 2002. The Effect of State Funeral Regulations on Cremation Rates: Testing for Demand Inducement in Funeral Markets. The Journal of Law and Economics. 45 (1): 199-225.

Jalland P. 2006. Changing Ways of Death in Twentieth-Century Australia: War, Medicine, and the Funeral Business. Sydney: University of New South Wales Press.

Laderman G. 2005. Rest in Peace: A Cultural History of Death and the Funeral Home in Twentieth-Century America. New York: Oxford University Press.

McChesney F. 1990. Consumer Ignorance and Consumer Protection Law: Emprical Evidence from the FTC Funeral Rule. JL \& Pol. 7: 1.

Parsons B. 1999. Yesterday, Today and Tomorrow. The Lifecycle of the UK Funeral Industry. Mortality. 4 (2): $127-145$.

Ritzer G. 1977. Working, Conflict and Change. 2d ed. Englewood Cliffs, NJ: Prentice-Hall, Inc.

Sanders G. 2009. «Late» Capital: Amusement and Contradiction in the Contemporary Funeral Industry. Critical Sociology. 35 (4): 447-470.

Seale C. 1998. Constructing Death: The Sociology of Dying and Bereavement. Cambridge: Cambridge University Press.

Smith R. G. E. 1996. The Death Care Industries in the United States. Jefferson, NC: McFarland.

Stark D. 2009. The Sense of Dissonance: Accounts of Worth in Economic Life. Princeton, NJ: Princeton University Press.

Suzuki H. 2002. The Price of Death: The Funeral Industry in Contemporary Japan. Stanford: Stanford University Press. 
Thompson W. 1991. Handling the Stigma of Handling the Dead: Morticians and Funeral Directors. Deviant Behavior. 12 (4): 403-429.

Trompette P. 2011. Political Exchanges in the French Funeral Market. Management \& Organizational History. $6(1): 13-35$.

Trompette P. 2013. The Politics of Value in French Funeral Arrangements: Three Types of Moral Calculation. Journal of Cultural Economy. 6 (4): 370-385.

Van Maanen J. 1988. Tales of the Field: On Writing Ethnography. Chicago: University of Chicago Press.

Vélez-Zapata C. 2012. Contributions of Anthropology to the Study of Organization: The Case of Funeral Home. INTECH Open Access Publisher. URL: http://cdn.intechopen.com/pdfs/33721/InTech-Contributions of_anthropology_to_the_study_of_organization_the_case_of_funeral_home.pdf (дата обращения: 13.01.2017).

Walter T. 2005. Three Ways to Arrange a Funeral: Mortuary Variation in the Modern West. Mortality. 10 (3): 173-192. 


\title{
BEYOND BORDERS
}

\section{Sergei Mokhov}

\section{Handling the Ambiguity and Stigma: Ethnography of a Local Funeral Market}

\author{
MOKHOV, Sergei - \\ Postgraduate student, \\ National Research University \\ Higher School of Economics. \\ Address: 20 Myasnitskaya \\ str., 101000 Moscow, Russian \\ Federation.
}

\section{Email: svmohov.hse@gmail.} com

\begin{abstract}
The Western funeral industry has been delimiting professional stigma since the middle of the 20th century. The business is now open, public, and socially responsible. By contrast, the Russian funeral market is still plagued by myths and stereotypes which lead Russian funeral directors to avoid any form of publicity. As a result, the Russian funeral industry is highly stigmatized. Why does such a situation exist? Can we assume that stigma is perpetuated by the professional community?
\end{abstract}

The article is based on the author's ethnographic notes that were collected as a result of undertaking field research in one of the central regions of Russia. In the first part, the paper describes common funeral market models and shows the basic differences present in the Russian model. The second part provides examples from the ethnographic work. In the third part, some notes about funeral market workers are made.

The article's conclusion consists of several statements. First, that the Russian funeral market has a number of distinctive features: a weak and even spontaneous institutionalization; the prevalence of informal practices; and a dysfunctional infrastructure. In addition, the professional structure is quite closed to the entrance of new players and hierarchically organized according to the principles of a criminal society. This structure can be described in terms of David Stark's concept of ambiguity, meaning that the funeral market is able to function effectively only if its ambiguous status is preserved. From this perspective, stigma is a tool of conservation of ambiguity.

Keywords: Russian funeral market; funeral director; professional stigma; death care industry; funeral industry; anthropology of death.

\section{Acknowledgements}

This research was supported by 'Khamovniky’ fund (project No. 2016 008).

\section{References}

Abelev M., Rozhkov S., Zul'fugarzade T. (2006) Pokhoronnoe delo v Rossii [The Funeral Business in Modern Russia]. Zamestitel'glavnogo vracha [Assistant to the Chief-Physician], no 4, pp. 137-140 (in Russian).

Barkov A., Grachev R. (2013) Rynok ritual'nykh uslug: problemy grazhdansko-pravovogo regulirovaniya [Russian Funeral Market: The Problem of Law Regulation], Moscow: Izdatel'stvo "Yurlitinform" (in Russian). 
Blayac T., Bougette P., Montet C. (2012) How Consumer Information Curtails Market Power in the Funeral Industry. SSRN Electronic Journal. Available at: http://www.lameta.univ-montp1.fr/Documents/DR201212.pdf (accessed 26 December 2016)

Blizitsya konets ritual'noy podrabotki? [Nearing the End of Ceremonial Jobbing] (2012). Forum sudebnykh medikov. Available at: http://www.sudmed.ru/index.php? showtopic=23829 (accessed 13 January 2017) (in Russian).

Bremborg A. (2006) Professionalization without Dead Bodies: The Case of Swedish Funeral Directors. Mortality, vol. 11, no 3, pp. 270-285.

Cahill S. E. (1999) The Boundaries of Professionalization: The Case of North American Funeral Direction. Symbolic Interaction, vol. 22, no 2, pp. 105-119.

Carden P. (2001) Rising from the Dead: Delimiting Stigma in the Australian Funeral Industry. Health Sociology Review, vol. 10, no 2, pp. 79-87.

Filippova S. (2009) Kladbishche kak simvolicheskoe prostranstvo dlya sotsial'noy stratifikatsii [Cemetery as a Symbolic Space of Social Stratification]. Zhurnal sotsiologii i sotsial'noy antropologii [Journal of Sociology and Social Anthropology], vol. 12, no 4, pp. 80-96 (in Russian).

Elutina M., Filippova S. (2010) Ritual'nye pokhoronnye praktiki: soderzhatel'nye izmeneniya [The Substantive Changes in Funeral Practices]. Sotsiologicheskie issledovianiya, no 9, pp. 86-94 (in Russian).

Goffman E. (1963) Stigma: Notes on the Management of Spoiled Identity, Englewood Cliffs, NJ: PrenticeHall, Inc.

Harrington D. (2007) Markets Preserving Funeral Markets with Ready-to-Embalm Laws. The Journal of Economic Perspectives, vol. 21, no 4, pp. 201-216.

Harrington D., Krynski K. (2002) The Effect of State Funeral Regulations on Cremation Rates: Testing for Demand Inducement in Funeral Markets. The Journal of Law and Economics, vol. 45, no 1, pp. 199-225.

Jalland P. (2006) Changing Ways of Death in Twentieth-Century Australia: War, Medicine, and the Funeral Business, Sydney: University of New South Wales Press.

Laderman G. (2005) Rest in Peace: A Cultural History of Death and the Funeral Home in Twentieth-Century America, New York: Oxford University Press.

McChesney F. (1990) Consumer Ignorance and Consumer Protection Law: Emprical Evidence from the FTC Funeral Rule. $J L \&$ Pol. no 7, p. 1.

Moiseeva E. (2013) Tvoya poslednyaya pokupka vybrannaya kem-to drugim [Your Last Purchase but Chosen Not by You: How Buyers Make Their Choices in the Market for Funeral Services]. Journal of Economic Sociology = Ekonomicheskaya sotsiologiya, vol. 1, no 14, pp. 13-22. Available at: https://ecsoc.hse. $\mathrm{ru} / 2010-11-3 . h t m l$ (accessed 20 January 2017) (in Russian).

Mokhov S. (2016) Rynok ritual'nykh uslug v sovremennoy Rossiss: polomka pokhoronnoy infrastruktury kak vlastnyy resurs [Death Care Industry in Contemporary Russia: A Breakdown of Infrastructure as a Power Resource]. Sotsiologiya vlasti, vol. 28, no 4, pp. 83-104 (in Russian). 
Mokhov S. (2017) Rynok ritual'nykh uslug: opyt etnografii sensitivnogo polya [Funeral Market in Contemporary Russia: Ethnography in Sensitive Research]. Teleskop: zhurnal sotsiologicheskikh i marketingovykh issledovaniy, no 1 (Forthcomming) (in Russian).

Mokhov S. V., Zotova V. (2017) Delo ob ograde, stolike i skam'e: rezhimy spravedlivosti v praktikakh raspredeleniya mest na kladbishche [The Case of the Fence, Table and Bench: Orders of Worth in the Allocation of Places within a Cemetery]. Zhurnal issledovaniy sotsialnoy politiki, no 1 (forthcomming) (in Russian).

Oleynik A. (2001). Tyuremnaya subkul'tura v Rossii: ot povsednevnoy zhizni do gosudarstvennoy vlasti [Criminal Subculture in Modern Russia: Common Live and Power], Moscow: Infra-M (in Russian).

Parsons B. (1999) Yesterday, Today and Tomorrow. The Lifecycle of the UK Funeral Industry, Mortality, vol. 4, no 2, pp. 127-145.

Pochemu na pokhorony kuryanam prikhoditsya kopit' neskol'ko let? [Why do Citizens of Kursk city need to Save Money for Funerals All Their Life?] (2012) Argumenty i fakty. Chernozem'e. Available at: http:// www.chr.aif.ru/society/history/183535 (accessed 20 January 2017) (in Russian).

Reshenie po sudebnomu delu [The Decision on the Court Case] (2012) Available at: http://lenobl.fas.gov.ru/ solution/6952 (accessed 20 January 2017) (in Russian).

Ritzer G. (1977) Working, Conflict and Change. 2nd ed., Englewood Cliffs, NJ: Prentice-Hall, Inc.

Romanov P. (1996). Protsedury, strategii, podkhody "sotsial'noy etnografii" [Procedures, Strategies, Approaches of "Social Ethnography”]. Sotsiologicheskiy zhurnal, no 3-4, pp. 138-148 (in Russian).

Sanders G. (2009) "Late" Capital: Amusement and Contradiction in the Contemporary Funeral Industry. Critical Sociology, vol. 35, no 4, pp. 447-470.

Seale C. (1998) Constructing Death: The Sociology of Dying and Bereavement, Cambridge: Cambridge University Press.

Silchenko T. (2016) Rynok ritual'nykh uslug v otsenkakh naseleniya goroda Abakana [Funeral Services Market in the Estimates of the Population of the City of Abakan]. Psikhologiya, sotsiologiya i pedagogika, no 5. Available at: http://psychology.snauka.ru/2016/05/6762 (accessed 20 January 2017) (in Russian).

Smith R. G. E. (1996) The Death Care Industries in the United States, Jefferson, NC: McFarland.

Stark D. (2009) The Sense of Dissonance: Accounts of Worth in Economic Life, Princeton, NJ: Princeton University Press.

Sudebnye akty [Judicial Act] (2017) Available at: http://sudact.ru/regular (accessed 20 January 2017) (in Russian).

Suzuki H. (2002) The Price of Death: The Funeral Industry in Contemporary Japan. Stanford: Stanford University Press.

Thompson W. (1991) Handling the Stigma of Handling the Dead: Morticians and Funeral Directors. Deviant Behavior, vol. 12, no 4, pp. 403-429. 
Trompette P. (2011) Political Exchanges in the French Funeral Market. Management \& Organizational History, vol. 6, no 1, pp. 13-35.

Trompette P. (2013) The Politics of Value in French Funeral Arrangements: Three Types of Moral Calculation. Journal of Cultural Economy, vol. 6, no 4, pp. 370-385.

Van Maanen J. (1988) Tales of the Field: On Writing Ethnography, Chicago: University of Chicago Press.

Vélez-Zapata C. (2012) Contributions of Anthropology to the Study of Organization: The Case of Funeral Home. INTECH Open Access Publisher. Available at: http://cdn.intechopen.com/pdfs/33721/InTech-Contributions_of_anthropology_to_the_study_of_organization_the_case_of_funeral_home.pdf (accessed 20 January $2017 \overline{7}$.

Vydacha svidetel'stva o smerti "ne-rodstvennikam" [Providing Non-Relatives with Death Records] (2014) Forum sudebnykh medikov. Available at: http://www.sudmed.ru/index.php?showtopic=18080 (accessed 13 January 2017) (in Russian).

Walter T. (2005) Three Ways to Arrange a Funeral: Mortuary Variation in the Modern West. Mortality, vol. 10, no 3, pp. 173-192.

Citation: Mokhov S. (2017) Upravlyaya neopredelennost'yu i stigmoy: regional'nyy rynok ritual'nykh uslug v etnograficheskikh zametkakh [Handling the Ambiguity and Stigma: Ethnography of a Local Funeral Market]. Journal of Economic Sociology = Ekonomicheskaya sotsiologiya, vol. 18, no 1, pp. 28-50. Available at: https://ecsoc.hse.ru/2017-18-1.html (in Russian). 


\section{ДЕБЮТНЫЕ РАБОТЫ}

\section{Е. А. Бейлина, Д. С. Кантер, А. А. Клементьев, Н. С. Лялина \\ Мотивы и институциональные условия переработок}

(на примере офисных служащих г. Москвы) ${ }^{1}$

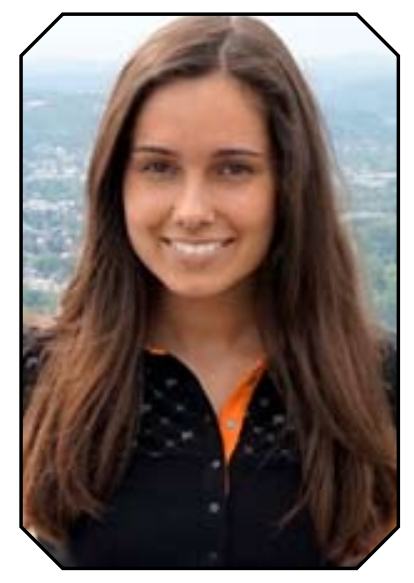

\section{БЕЙЛИНА Елена}

Анатольевна -

студентка бакалаврской программы

«Социология»

факультета социальных наук НИУ ВШЭ, стажёр-исследователь Лаборатории экономикосоциологических исследований НИУ ВШЭ.

Адрес: Россия, 101000 , г. Москва, ул. Мясницкая, д. 20.

Email: lenabelina@bk.ru
Работа посвящена изучению феномена переработок у офисных служащзих. Статистические данные показывают, что многие россиянеработают больше 40 ч в неделю, то есть законодательно закреплённого максимума, уходящего корнями в период массовой распространённости физического труда. Возрастающая доля третичного и четвертичного секторов экономики наталкивает на гипотезу о том, что «нормальная» 40-часовая рабочая неделя является избыточным ограничением рабочего времени, и сами работники воспринимают норму иначе. Согласно имеюшимся исследованиям, феномен переработки может быть результатом как личностных особенностей индивида, так и институциональных и экономических изменений.

На основе 22 глубинных интервью был осуществлён анализ мотивов переработок, а также представлений офисных служащих о «нормальной» продолжительности рабочего дня и о границе между нормированным трудом и переработкой.

Выяснилось, что представления служащих о том, что такое переработка, сущеествуют не только в категории часов. Помимо формальной переработки - труда сверх предусмотренных заключённым договором часов, существует и неформальная, которая определяется трудящимися как ошутимое и нежелательное нарушение привычного образа жизни, баланса между работой и личным временем, что приводит к психологической и физической усталости, а в результате к потере «вкуса к жизни».

Также в статье представлена классификация причин и мотивов, приводящих к переработкам в среде офисных служащих. Выделены следуюшие мотивы: экономические (обеспечение карьерного роста или стабильности), социальные (следование нормам корпоративной культуры), психологические (избегание домашних проблем). Особое внимание уделено анализу институциональных условий труда (особенностям организационной структуры), которые могут быть причиной переработок.

Ключевые слова: переработки; мотивы переработок; восприятие переработок; корпоративная культура; трудовые отношения; социология труда; офисные работники.

Авторы работы выражают особую благодарность научному руководителю Маркину Максиму Евгеньевичу за помощь и комментарии на всех этапах проведения исследования. 


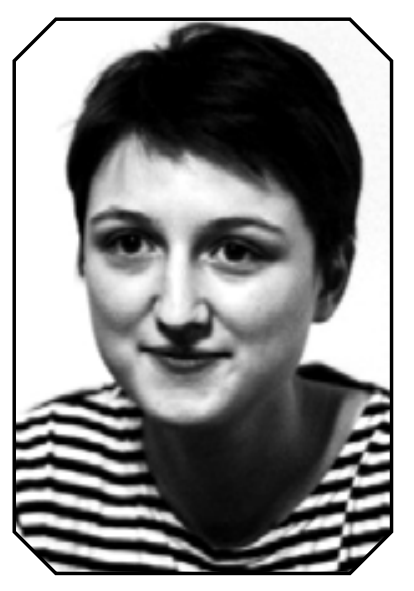

КАНTЕР Дарья

Сергеевна - студентка бакалаврской программы «Социология» фракультета социальных наук НИУ ВШЭ. Адрес: Россия, 101000 , г. Москва, ул. Мясницкая, д. 20.

Email: dariakanter@gmail. com

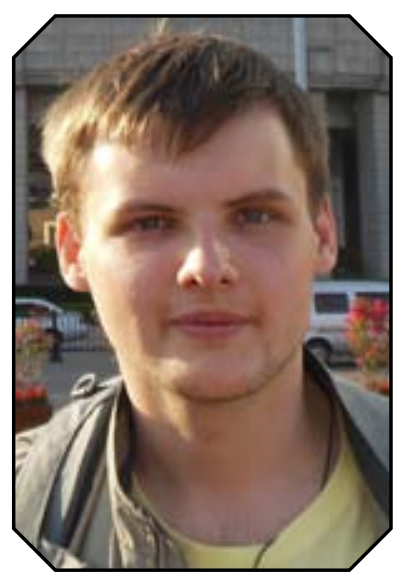

\section{КЛЕМЕНТЬЕВ}

\section{Александр} Александрович студент бакалаврской программы «Социология» факультета социальных наук НИУ ВШЭ. Адрес: Россия, 101000, г. Москва, ул. Мясницкая, д. 20.

Email: aaklementev@edu. hse.ru

\section{Переработка в современном мире: норма или атавизм?}

Согласно экономической теории работники сравнивают выгоды от дополнительных часов работы с издержками потери свободного времени и на этой основе принимают решение о желаемом количестве рабочих часов. Однако в реальности требования к длительности рабочего дня чаще устанавливаются работодателем, и количество обязательных часов работы указано в трудовом договоре работника [Böheim, Taylor 2004]. Согласно законодательству Российской Федерации максимально возможная продолжительность рабочей недели составляет 40 часов (см. ст. 91 Трудового кодекса РФ).

Можно предположить, что бо́льшая часть работающих людей предпочтёт не находиться на рабочем месте больше заявленного в законодательстве максимума. Действительно, в экономической теории труд рассматривается как антиблаго, издержка, которая необходима для производства товаров и услуг [Адамчук, Ромашов, Сорокина 1999]. Однако в постсоветской России наблюдается тенденция роста среднего количества трудовых часов работающих людей. Так, в 1992-2000 гг. трудовая нагрузка возросла с 153 до 171 час. в месяц. В 2000 г. почти половина работников трудилась больше нормы: 28\% - 42-56 час.; 18\% - более 56 час. в неделю [Денисова 2004]. Согласно исследованиям Росстата, более четырёх с половиной миллионов россиян в 2013 г. провели на рабочем месте больше разрешённых законом 40 час. в неделю, при этом 40\% из них потратили на работу более 51 часа [Структура занятых в экономике...].

Восьмичасовой рабочий день вполне вписывался в фордистскую систему организации производства, когда большая часть работников была занята физическим трудом [Томин 2014]. В современном мире происходят все большее сужение сферы производства и расширение сферы услуг, труд связан в основном с интеллектуальной деятельностью - производством и обработкой информации [Стребков, Шевчук 2009]. Считают ли сами работники восьмичасовой рабочий день нормой в условиях современности? Как они воспринимают задержку на рабочем месте дольше законодательно установленного срока? Если восьмичасовой рабочий день является нормой в сознании людей, то каковы причины переработок?

\section{Степень разработанности проблемы}

\section{Границы понятий «трудоголизм», «переработка» и «сверхзаня- mocmb»}

Феномен неоплачиваемого сверхурочного труда наёмных работников по-разному операционализируется и интерпретируется в социальных науках. Например, понятие «сверхзанятость» (overemployment) часто используется российскими и зарубежными экономистами при анализе и теоретическом моделировании рынка труда или при сравнении макроэкономических показателей [Golden, Gebreselassie 2007; Новый англо-русский толковый словарь...]. 


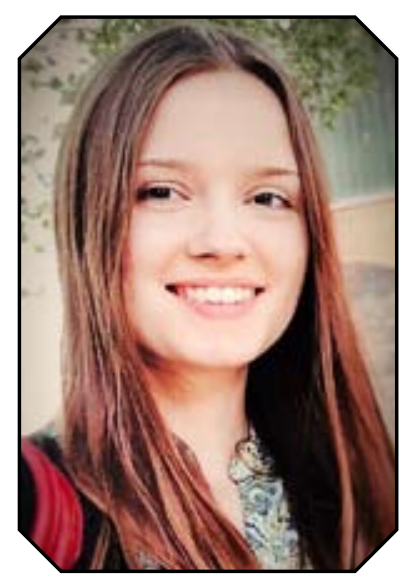

\section{ЛЯЛИНА Надежда}

Сергеевна - студентка

бакалаврской

программы

«Социология»

фракультета социальных наук НИУ ВШЭ.

Адрес: Россия, 101000, г. Москва, ул. Мясницкая, д. 20.

Email: Iyalinanadya@ mail.ru
Психологи операционализируют явление с помощью термина «трудоголизм». В качестве причин называются внутренние противоречия, психологические проблемы, от которых он стремится отвлечься, погружаясь в работу, а также особенности индивида [Robinson 2000; Golden 2009; Ильин 2011]. Различают также «псевдотрудоголизм» — это усердная работа с целью получения бо́льшего финансового вознаграждения или вынужденная задержка на работе по приказу начальства [Ильин 2011].

Л. Голден, исследуя влияние экономических, психологических, социальных и институциональных причин на увеличение числа часов, затрачиваемых на труд жителями США, использует термин overwork («переработка») [Golden 2009]. По мнению Голдена, трудоголизм, вызванный внутренними проблемами индивида, является лишь одним из видов, составной частью более общего понятия «переработка» [Golden 2009]. В данной работе мы остановимся именно на этом термине. Понятие «переработка» будет интерпретироваться как превышение нормы труда, вызванное как внешними, так и внутренними причинами.

\section{Норма труда в историческом и правовом контекстах}

Впервые о нормировании рабочего дня заговорили участники рабочего движения и его идеологи: профсоюзы в индустриализированной Британии стали влиятельными настолько, чтобы активно лоббировать сокращение трудового дня [Кузьминов et al. 2005]. Огласку получила выведенная Робертом Оуэном формула «8 часов работы, 8 часов восстановления, 8 часов сна» [Вознесенская 1958]. Идеи Оуэна были переняты Марксом и Энгельсом, которые в 1866 г. на конгрессе Международного товарищества трудящихся призвали к введению восьмичасового рабочего дня [Маркс, Энгельс 1954].

В России рабочий день впервые был законодательно ограничен уже в конце XIX века, также под напором рабочего движения, до 11,5 час. Октябрьская революция дала начало социалистическому эксперименту, в рамках которого был установлен восьмичасовой рабочий день [Кузьминов et al. 2005].

Представления о норме труда в различные исторические периоды можно, вероятно, косвенно оценить, ознакомившись со статистическими данными о средней длине рабочей недели. Имеющиеся данные по этому показателю демонстрируют снижение рабочей нагрузки в США с 70 час. в неделю в начале XIX века до 40 час. в 1938 г. С этого момента и до 1970-х гг. значительных изменений в средней продолжительности рабочей недели не происходило, но затем она стала расти, причём неравномерно: наибольший рост произошёл среди высокообразованных, высокооплачиваемых сотрудников среднего и старшего возрастов. Этот феномен обозначают как «поляризацию продолжительности рабочего времени» [Golden 2009].

Обратимся к понятию «норма труда» в современной России. Существует мнение, что в XXI веке 40 час. в неделю и восьмичасового рабочего дня недостаточно для гармоничного развития и прогресса в экономике [Гусов 2008]. С. В. Соловьёва отмечает, что современное российское законода- 
тельство содержит нормы, которые способствуют развитию массового трудоголизма среди работающего населения (например, возможность привлекать сотрудника к работе по совместительству, заменять отпуск денежной компенсацией, особый статус так называемого ненормированного рабочего графика в Трудовом кодексе) [Соловьёва 2013].

\section{Описание причин и мотивов переработок в социальных науках}

Мотивы переработок изучались в рамках нескольких социальных наук. Обзор работ из области психологии позволил выявить несколько возможных причин для развития феномена трудоголизма и, как следствие, возникновения переработок: это, во-первых, особенности семейного воспитания индивида; во-вторых, такие личностные качества, как перфекционизм, уверенность в собственных силах, целеустремлённость и сознательность; в-третьих, разнообразные личные проблемы, неприятные жизненные ситуации и эмоции, а также нереализованная потребность в признании [Robinson 2000; Bozionelos 2004; Ng, Sorensen, Feldman 2007; Burke, Davis, Flett 2008; Liang, Chu 2009; Ильин 2011].

Экономисты, говоря о неоплачиваемой переработке, так или иначе приходят к выводу, что неоплаченный труд сотрудников компенсируется получением выгод в долгосрочном периоде [Pannenberg 2005; Van Echtelt et al. 2007]. Чтобы получить надбавку к заработной плате, повышение по работе или просто не попасть под сокращение, сотрудники должны найти способ «сигнализировать» начальнику о своей ценности. Именно неоплачиваемая переработка, по мнению некоторых экономистов, является таким сигналом [Babbar, Aspelin 1998; Anger 2008], а также инструментом поддержания позитивной репутации [Fama 1991], способом инвестировать в человеческий капитал [Shaw 1989; Booth, Francesconi, Frank 2003], которые, в свою очередь, позволяют максимизировать соотношение «доход - усилия» в долгосрочном периоде.

Несмотря на то что в некоторых экономических работах учитывается роль социальных мотивов (например, стремление не отставать от своей референтной группы в уровне доходов и потребления [Veblen 1899; Duesenberry 1949; Schor 1992; Bell, Freeman 2001; Bowles, Park 2005; Stark, Tanajewski 2008]), авторы этих исследований всё равно связывают стремление работать больше с желанием получать больший доход.

Хотя возможность получения вознаграждения в долгосрочном периоде за формально неоплачиваемую переработку в текущем периоде существует, работники далеко не всегда задерживаются на работе, руководствуясь именно этими соображениями. Особенности организации рабочего процесса в эпоху постфордизма могут способствовать неоплачиваемым переработкам [Van Echtelt et al. 2007].

На сегодняшний день в результате стремительного развития высоких технологий, увеличения темпов изменений в бизнес-среде и роста глобальной конкуренции главной задачей организации становится выживание в условиях неопределённости, для чего необходимо иметь возможность быстро реагировать на новые вызовы и легко адаптироваться к изменениям. В связи с этим существовавшая долгое время иерархическая структура организации перестаёт быть эффективной, поскольку не является достаточно гибкой. Понимая это, компании по всему миру начинают реорганизовывать внутреннюю структуру таким образом, чтобы быть способными быстро принимать решения и внедрять инновации. Распространяется гетерархическая форма организации, для которой характерны высокий уровень взаимозависимости между рабочими командами и горизонтальное распределение власти [Старк 2001]. Чтобы оставаться конкурентоспособными, фирмы идут на радикальную децентрализацию: в инновации вовлекаются сразу несколько департаментов организации. Генерацией идей занимаются разные команды, которым необходимо взаимодействовать друг с другом, и координировать действия иерархическим образом становится неэффективно. Излишний бюрократизм лишь снижает эффективность, посколь- 
ку решения должны приниматься быстро, в связи с чем команды приобретают достаточно большую автономию от центральной системы управления [Старк 2001: 122]. В организациях подобного типа команды, как правило, работают над проектами в условиях жёстких дедлайнов и наличия высоких требований относительно качества работы. Организовывая свой труд, работники отталкиваются не от количества рабочих часов, которое им необходимо отработать за день или неделю, а от установленных сроков выполнения проекта [Van Echtelt et al. 2007].

Командная работа над проектами, когда каждый несёт ответственность не только перед собой или начальником, но и перед коллегами, наличие дедлайнов, высоких требований к качеству работы приводят к тому, что работники принимают решение выполнить задание до конца, прежде чем уйти, задержаться на работе, чтобы дождаться важного звонка из-за границы, не уходить с важной конференции только потому, что официальное время работы закончено [Van Echtelt et al. 2009]. Успех команды сильно зависит от уровня кооперации и обмена информацией среди её членов. Чтобы поддерживать высокую эффективность труда команды, коллеги могут задерживаться на работе, исправляя ошибки или выполняя ту часть работы, которую должен был сделать отсутствующий человек [Bell, Hart 1999; Jirjahn 2008]. Командный труд способен позитивно сказываться на приверженности тому или иному роду деятельности, поэтому необходимость оставаться на работе дольше, чем официально требуется, может быть подкреплена и позитивной внутренней мотивацией [Schor 1992; Hochschild 1997].

Положительная корреляция между уровнем заработной платы и количеством часов, проведённых на работе, может быть интерпретирована в терминах теории дарообмена. Фирмы порой устанавливают заработную плату выше рыночного уровня, чтобы побудить работников сделать «ответный подарок» в виде формально неоплачиваемой переработки [Akerlof 1984; Anger 2005].

Сравнительное рассмотрение нормативно-этических систем в различные периоды российской истории показало, что отношение к труду как к социальной миссии может выступать причиной своеобразного «обесценивания» заработной платы: индивид, веря в важность своей работы как таковой или в необходимость помощи коллективу, не рассматривает материальную компенсацию за потраченные усилия как нечто значимое, поэтому готов к неоплачиваемому труду. Такая «асимметрия» обмена между работником и работодателем может интерпретироваться как советское наследие: 25-30 лет назад никакого «работодателя» идеологически не существовало; его замещали абстрактный «народ» и «коммунистическое будущее». Интересно, что приверженцами подобной «социоцентричной» логики чаще становились работники с высоким профессиональным статусом [Магун 1998]. Среди национальных черт культуры труда выделяют и способствующие формированию ненормированного рабочего графика [Шкаратан 2003]:

— историческое отсутствие механизмов психологического сдерживания, «принуждения» к труду;

— отсутствие предрасположенности к монотонному труду, низкая дисциплинированность;

— мобилизационные («авральные») черты трудовой культуры и, как следствие, «волновой» ритм работы.

Предпринимались и попытки создания некоторой междисциплинарной модели, объясняющей феномен переработок. Так, Л. Голден предложил одновременно учитывать текущую зарплату в реальном выражении, предполагаемую траекторию заработной платы и планы на будущее, статус и референтные группы индивида, выгоды от самого рабочего процесса, спрос на труд со стороны работодателя [Golden 2009]. 
Группа израильских учёных разделила предполагаемые причины трудоголизма на две группы: внутренние (перфекционизм, уверенность в собственных силах и т. п.) и внешние (организационная культура и корпоративный климат) [Mazzetti, Schaufeli, Guglielmi 2014]. Авторы замечают, что на факт наличия переработок оказывают влияние не только личностные особенности человека и организационный климат, но и взаимодействие между ними, что будет учтено в настоящей работе.

Обобщая рассмотренные источники, можно сказать, что переработка является продуктом целого ряда предпосылок: на микроуровне это психологические особенности индивида, в то время как в более крупном масштабе переработкам способствуют институциональные и экономические изменения, а также значительные сдвиги в культуре труда.

\section{Методологическая основа исследования}

Изучение феномена переработок на всем разнообразии профессий и типов занятости не позволило бы достичь смысловой насыщенности собранных данных. Было принято решение сконцентрироваться на наиболее распространённой категории занятых — офисных служащих.

Объектом исследования являются офисные работники Москвы, занятые полный рабочий день на протяжении всей рабочей недели. Под офисными работниками мы понимаем наёмных служащих, занятых умственным трудом и проводящих свой рабочий день вне дома, в помещении компании (офисе).

Были сформулированы следующие задачи исследования:

— выявить мотивы офисных работников (не) перерабатывать;

— выявить институциональные причины существования переработок у офисных работников;

- выявить представления офисных служащих о продолжительности рабочего дня, то есть о норме и переработке и о границах между ними.

Реализованный тип выборки - целевая выборка с максимальной вариацией. Поскольку наша исследовательская концепция заключается в анализе представлений различных работников о норме, такая выборка позволит выявить наибольшее возможное число представлений. В ходе исследования были взяты 22 полуструктурированных интервью (см. таблицу П.1).

Ключевыми параметрами, которые учитывались при отборе информантов, являются наличие и (или) отсутствие подчинённых и семейный статус.

Должностной статус (наличие и (или) отсутствие подчинённых). Статистика показывает, что в России различным профессионально-должностным группам свойствен разный уровень трудовой нагрузки [Денисова 2004]. Разница в количестве рабочих часов может свидетельствовать об отличиях в подходах к работе и рабочему времени, интерпретации важности своей работы и т. д. Действительно, управленческая должность, в отличие от позиции исполнителя, подразумевает ответственность не только за собственный результат, но и в первую очередь за эффективность организации труда подчинённых.

Семейный статус (факт брака или сожительства, наличие несовершеннолетних детей). Мы полагаем, что факт наличия семьи и детей может значительно изменять установки людей по отношению к трудовой деятельности. С одной стороны, наличие дома детей, которые требуют постоянного ухода и внимания, может привести к тому, что человек предпочтёт находиться на рабочем месте как можно 
меньше времени. С другой стороны, наличие семьи и детей может значительно увеличить потребность домохозяйства в стабильном, достаточно высоком уровне дохода, что способно побудить индивида работать усерднее, чтобы обеспечить устойчивость своего положения на работе и высокий уровень оплаты труда. Наконец, семья бывает потенциальным источником проблем и жизненных неурядиц, вызывающих у человека психологический дискомфорт, в результате чего индивид, чтобы избежать дискомфорта дома, задерживается на работе [Ильин 2011].

Таким образом, на пересечении двух категорий образуются четыре целевые группы информантов. Итоговая матрица выборки представлена в таблице 1.

Матрица выборки

Таблийа 1

\begin{tabular}{lccc}
\hline & \multirow{2}{*}{ Критерии отбора } & \multicolumn{2}{c}{ Должностной статус } \\
\cline { 3 - 4 } & Есть подчинённые & Нет подчинённых \\
\hline Наличие несовершен- & Есть несовершеннолетние дети & 4 & 3 \\
нолетних детей & Нет несовершеннолетних детей & 6 & 9 \\
\hline
\end{tabular}

Также при отборе информантов мы стремились обеспечить половозрастной плюрализм. Особое внимание уделялось включению в выборку людей, чья социализация проходила в период командной экономики, кто мог интернализировать специфические представления о труде, отличные от тех, которые усваивались последующими поколениями [Магун 1998]. Таким образом, в выборку было необходимо включить как информантов старше 40 лет, так и тех, чья социализация проходила уже в условиях рынка, то есть людей в возрасте 20-30 лет.

Различия в типичных социальных ролях мужчин и женщин в современном российском обществе также входят в число факторов, оказывающих влияние на структуру занятости и в том числе на феномен переработок. Так, женщины могут чаще отказываться от переработок в пользу работы по дому, ухода за детьми и т. д. [Snir, Harpaz 2006].

Поиск информантов начинался с использования социальных сетей «Вконтакте» и Facebook, где через знакомых мы подбирали людей с разным должностным статусом. Помимо места работы и должности, в социальных сетях люди часто указывают и другую личную информацию: возраст и семейное положение. Если по данным критериям человек нам подходил, то он становился нашим потенциальным информантом.

Кроме того, в гайде интервью присутствовали вопросы на сравнение продолжительности собственного рабочего дня с рабочим днём друзей и знакомых, а также людей других профессий, в связи с чем сотрудники организаций сами указывали нам на потенциально возможных информантов.

\section{Мотивы и институциональные условия переработок (по результатам исследования)}

\section{Что такое переработка?}

Какой смысл вкладывается в понятие «переработка»? Какое восприятие переработки формируется у офисных служащих? На основе проведённых интервью можно выделить два блока подходов к восприятию переработки: (1) формальная переработка и (2) переработка в субъективном восприятии офисного работника, то есть неформальная. 
Информантам задавался прямой вопрос о переработке: «Вы лично перерабатываете? Лично для Вас переработка - это когда...?». На этот вопрос они начинали отвечать в категориях дополнительных часов или дополнительных задач, материального вознаграждения, то есть описывать то, что, по мнению офисных сотрудников, нарушается согласно установленному законодательству или не прописано в трудовом договоре. Именно эти характеристики мы выделили в отдельную группу формальной переработки. Когда далее сотрудники начинали рассуждать о том, что они считают переработкой, на первый план выходили личное и субъективное восприятие работы, то есть изменение привычного образа жизни и нарушение баланса между работой и личной жизнью, а также психологическая и физическая усталость. Данные характеристики мы отнесли ко второму типу переработки - к неформальной.

Формальная переработка может определяться информантом как работа сверх положенного времени или усиление её интенсивности, то есть выполнение большего числа задач за то же время. Иными словами, переработка - это дополнительная работа, которая не входит в основные обязанности. Такая работа заключается в выполнении заданий и поручений, которые зачастую не прописаны в трудовом договоре, а также обязанностей другого сотрудника.

Рабочий день недаром регламентируется стандартно, там в определённое время. То есть у нас стандартный офисный вариант с 9 до 6. Всё, что после 18:00, считается переработкой (Наталья, 45 лет, помощник директора, замужем, совершеннолетний ребёнок).

Офисные сотрудники отмечали, что если за какой-то избыточный труд, за отработку лишних часов они получают материальное вознаграждение, то это не считается переработкой. Один из информантов отмечал: если ему оплачивается то, что он делает по выходным, то переработки не существует, ведь после выплаты денежного вознаграждения такой вид деятельности превращается в обычную работу.

Совершенно иной подход к определению понятия «переработка» (неформальная переработка) заключается в том, что данное явление ассоциируется у информантов с какими-то личными лишениями и недугами. Так, информанты говорили о том, что переработка начинается, когда становится морально и физически трудно работать: появляются усталость, нервозность. Как следствие, нехватка свободного времени, нарушение баланса между работой и личной жизнью могут привести к тому, что работа перестанет приносить былое удовольствие.

Также переработка ассоциируется у офисных работников с выполнением обязанностей в нерабочее время, «когда уже не настроен на работу». При этом работу, которую необходимо выполнить дома, иногда сравнивают со школьным домашним заданием: за невыполнение могут последовать санкции.

\section{Мотивы (не) перерабатывать}

Представляя результаты анализа, мы будем использовать понятие «мотив» как «вербальное поведение, направленное на выбор суждений для объяснения поведения» [Ромашов 2001]. Иными словами, нас интересует то, какие смыслы работники вкладывают в сверхурочный труд или отказ от него, как аргументируют свои и чужие действия.

\section{Почему офисные служащие перерабатывают?}

Первую группу мотивов переработки можно обозначить как экономические. Информанты, объясняя своё поведение или поведение других людей, обращаются к теме материальной выгоды, рыночных отношений, условий на рынке труда. Так, одним из мотивов может выступать угроза увольнения, вынуждающая работника трудиться больше. Информанты связывали количество труда с его оплатой, выражая готовность работать больше ради более высокого денежного вознаграждения. 
Также в данной мотивационной рамке можно говорить о явлении экономического «сигнализирования»: перерабатывая, сотрудник демонстрирует работодателю свою лояльность, готовность и желание трудиться, зарабатывать положительную репутацию, потенциально приводящую к повышению [Anger 2008; Babbar, Aspelin 1998].

Это вот срабатывает такая штука, что если ты перерабатываешь < .. > у тебя есть большой шанс, что ты задержишься в этой компании (Оксана, 29 лет, руководитель проекта по внедрению информационных систем, не замужем, детей нет).

Отдельным подвидом подобного «сигнализирования» может выступать переработка с целью дальнейшего «удорожания» своих позиций на рынке труда в целом. В институциональной теории подобные сигналы позволяют снизить асимметричность информации [Одинцова 2007]; факт опыта работы на престижной позиции позволяет работодателю сделать выводы о профпригодности соискателя. В свою очередь, работники, заинтересованные в эффективном карьерном продвижении, соглашаются на достаточно рутинный и даже механический (проставление печатей, оформление документации) и низкооплачиваемый труд в обмен на престиж компании. Такой мотив, закодированный нами как «строчка в резюме», был описан молодыми работниками, делающими первые шаги в карьере.

Следующая группа мотивов была обозначена нами как социальные. Так, например, информанты объясняли переработки корпоративной культурой организации.

Корпоративная культура как реплицируемый способ организации смыслов, которыми наделяется работа, встречается и в теоретических работах, моделирующих возможные факторы увеличения длительности рабочего дня [Mazzetti, Schaufeli, Guglielmi 2014].

Эмпирический материал показывает, что задержка на работе не всегда вызывает у работников негативные ассоциации.

Мы задержсивались до семи, иногда до восьми <..> Mbы это делали все вместе <... Мы заваривали себе чай, готовили что-нибудь вкусное, работу дорабатывали. Мне несложно было загружаться и что-нибудь делать (Ксения, 19 лет, ведущий специалист по поддержке продаж, не замужем, детей нет).

Соотнося такую «связь с коллективом» с теорией, можно сказать, что общение, социальные контакты является одной из вторичных выгод, получаемых от работы [Golden 2009]. В таком случае переработка становится не просто особенностью трудового поведения, но и способом удовлетворения индивидуальных потребностей личности (общение, принадлежность к общности или др. [Егоршин 2006]).

Эмпирика также продемонстрировала, что работники могут задерживаться на работе дольше, если коллегам или начальнику необходима помощь. При этом информанты объясняли своё желание помочь по-разному. Так, например, была озвучена идея помощи не безвозмездной, но с ожиданием «встречных действий» в отложенном времени. Такое поведение можно вписать в концепцию реципрокности [Поланьи 2002].

Практики переработок также могут быть отражением того, как трудящийся понимает справедливость в отношениях обмена между работником и работодателем [Akerlof 1984].

По договорённости я уходила с серединь дня, руководитель только «за»: «О, классно, курсы, расскажешь мне потом». Я под этим понимаю, что так: я здесь ушла на три часа раньше, 8 
следующий раз, на неделе, мне надо по часу восполнить (Марина, 26 лет, специалист по брендменеджменту, не замужем, детей нет).

Также как один из поводов задержаться на работе, чтобы помочь другим в выполнении своих задач, можно выделить полученное взамен ощущение собственной незаменимости и важности.

Как сказал N. (Имя скрыто. - Авторы), кроме тебя никто это не сделает хорошо <...> Я была готова всем помочь. Финансовый директор, у него какие-то проблемы, приехал поздно, никого уже нет, но есть я (Наталья, 45 лет, помощник директора, замужем, совершеннолетний ребёнок).

Иная интерпретация помощи - опора на «человеческие отношения» в коллективе или с начальством. Вероятно, изначально формальные отношения с начальством со временем были в этом случае дополнены социальными связями, что сделало отношения укоренёнными в социальной структуре. В такой ситуации просьба от начальника - не приказ вышестоящего руководства, а обращение друга [Грановеттер 2002].

Также любопытным оказалось то, что работники могут выбирать, кому из сослуживцев помочь, а кому нет, опираясь на наличие или отсутствие у них «кристально чистых мотивов». Работника может беспокоить этичность действий того, кому он помогает, что отсылает нас к представлениям о социальной справедливости.

По словам информантов, переработка может быть следствием установки, обозначенной нами как «если надо». Иными словами, допустимо работать больше тогда, когда это необходимо. Интересно, что такой мотив переработки звучал в интервью с теми информантами, чья деятельность связана с сезонностью, то есть периоды высокой активности (много заказов и сдач) сменяются «низким сезоном» (мало задач, почти нет работы). Можно сделать предположение, что подобная установка - это адаптация к специфике рабочего процесса, характеризующегося неодинаковой нагрузкой на работника в разные периоды. Также ответственность и обязательность, упоминаемые информантами при описании причин собственных переработок, отсылают к списку личностных качеств, которые, по мнению исследователей [Bozionelos 2004], могут способствовать подобным практикам.

Интересно, что фрагмент интервью, приведённый ниже, не только раскрывает восприятие «энергии» и «сил» работниками моложе 30 лет, но и отражает интернализированные нормативные предписания для людей старшего возраста, которым, напротив, работать много «некрасиво». Иными словами, если переработка молодого работника отражает его жизненные приоритеты и энергичность, то такое поведение более старших работников представляется выходящим за пределы нормы, «непозволительным».

<...> Ну ещё в силу того, что мы молодой коллектив < ..> нет никого в команде, кому больше, чем 30 лет <... $>$ То есть, если бы у нас был коллектив 40+, то как бы вряд ли кто-то перерабатывал, просто люди даже себе не позволяли бы такого: ну, некрасиво (Олег, 25 лет, генеральный директор малого бизнеса, не женат (есть девушка) детей нет).

В группе психологических мотивов, свойственных тем, кто работает сверх нормы, можно отметить желание держать трудовой процесс под контролем, уверенность в том, что иначе работа будет выполнена недостаточно качественно - всё это приводит к значительному увеличению объёмов работы и, как следствие, к переработкам. Одна из информанток (Мария, 27 лет, предприниматель, ранее - специалист по маркетингу, замужем, детей нет) самокритично заметила, что её желание полностью контролировать подчинённых приводит к их неэффективности, а то и вовсе к бездействию, в то время как сама она чересчур загружена, но не знает, как изменить ситуацию. 
Психологи отмечают, что подобный перфекционизм и нежелание делегировать работу другим может привести к трудоголизму и, как следствие, к переработкам [Burke, Davis, Flett 2008]. Желание работать больше может быть связано и с другими особенностями характера. Один из сюжетов был закодирован нами как «не нравится ничего не делать». В этом случае собственное рвение в работе объяснялось дискомфортом, который вызывает отсутствие занятий и задач.

Интересно также то, что работники оказываются готовы работать больше ради «важной цели». В целом, риторика, использующая аргументацию «большая цель - большие усилия», на наш взгляд, апеллирует к целеустремлённости (achievement motivation), потребности в достижении высоких результатов, которая является, согласно уже проведённым исследованиям, одним из главных предикторов трудоголизма и переработок [Ng, Sorensen, Feldman 2007].

Ещё одним поводом задержаться на работе стало избегание домашних проблем и неурядиц. Некоторые информанты описывали такое решение как «временную меру» на случай ссор, в то время как другие связывали подобное поведение с определённым жизненным этапом:

У меня такое было раньше (Задерживался на работе. - Авторы.), когда я жил с девушкой. А сейчас, в последнее время, в основном нет. Дома никаких опасностей нет (с меётся) (Виктор, 25 лет, программист, не женат, детей нет).

Логично добавить, что подобный мотив описывался только информантами, состоящими в отношениях и делящими жильё с партнёрами. Стоит отметить, что подобная ситуация причисляется психологами к одной из причин трудоголизма [Robinson 2000].

Сверхурочная работа также возможна из-за интереса к выполняемой задаче. Близким к такому мотиву является «энергетика молодости», с помощью которой информанты объясняли готовность молодых людей работать больше.

\section{Почему люди отказываются от переработок?}

Один из мотивов держаться в рамках «нормального» рабочего дня и не перерабатывать - это стремление поддерживать баланс между работой и остальными жизненными «векторами» (семья, увлечения и т. д.):

Эта (Переработка. - Авторы.) порочная практика. Она, в принципе, принята в агентствах, что надо до восьми, до девяти, до десяти... «А давайте все поедем на такси». Мне не нравится. Я считаю, что у них всех тоже есть мужья, жёны, дети, хобби, танго (улыба ется) и так далее... Поэтому я так наладила: встаю в семь, ухожу (Елена, 32 года, креативный директор, разведена, несовершеннолетний ребёнок).

Стремление к соблюдению такого баланса также может быть вызвано разными мотивациями. Одним из поводов для работы «в норме» является чувство вины перед супругом или детьми из-за того, что им уделяется недостаточно времени. Интересно, что подобный сюжет звучал только в интервью информанток-женщин. Феномен ролевого конфликта работающих женщин упоминается и в литератуpe [Алёшина, Лекторская 1983].

Желание оставить время «для жизни» может быть вызвано соображениями эффективности и описано в риторике выживания. По логике одной из информантов (Елена, 32 года, креативный директор, разведена, несовершеннолетние дети), поддержание баланса между работой и жизнью необходимо, по- 
скольку в случае выгорания и усталости от работы «всё рухнет». Иными словами, переработки делают риск «выгорания», неготовности работать дальше слишком высоким, что может закончиться плачевно в долгосрочной перспективе из-за обязательств, которые человек несёт перед семьёй.

Иногда задержка после формального окончания рабочего дня может быть девиантным поведением, которого индивиды пытаются избежать.

Сначала я автоматом задерживалась, я считала это нормой. Но потом я поняла, что все уходят вовремя, а я на полчаса там задерживаюсь. Думаю: «Фиг вам» (смеется) (Ксения, 19 лет, ведущий специалист по поддержке продаж, не замужем, детей нет).

Отмеченные мотивы являются обратным отражением «соревновательного презентеизма», описанного Симпсоном [Simpson 1998]. По логике информантки, фрагмент из интервью с которой приведён выше, престижно и одобряемо не задержаться на работе, а, напротив, уйти вовремя.

\section{Институциональные условия переработок}

Определённые работники обладают достаточно специфичными навыками или знаниями, которые работодателю трудно отыскать на рынке труда. Такие люди представляют собой ценность для организаций, которые всячески стараются стимулировать таких работников трудиться интенсивнее. Высокий спрос на труд таких работников обусловлен тем, что издержки на поиск, обучение и контроль людей с аналогичными компетенциями могут превышать размеры компенсации сверхурочных часов уже нанятому сотруднику [Golden 2009].

По нашим данным, заставить задержаться на работе могут специфические условия труда, не зависящие от самого индивида.

В нашем отделе переработки если и бывают, то только если тебе нужно кого-то ждать, чтобы он поставил подпись (Ирина, 45 лет, главный специалист службы технического обеспечения, замужем, двое детей).

Необходимость задерживаться вызвана особенностями организации рабочего процесса: труд работника завязан на взаимодействии с другими агентами, которые, в свою очередь, не имеют возможности выполнить свою «часть работы» в рамках установленного графика. Интересно, что подобное явление способно не только удлинять рабочий день, принуждая к ожиданию, «простаиванию» человеческого ресурса, но и нормализовать рабочий процесс. В интервью упоминались ситуации, когда сотрудник, занимающийся переговорами с поставщиками, уходил строго по окончании официального трудового дня, поскольку в этот момент закрывались офисы контрагентов и оставаться на рабочем месте было бессмысленно.

Интересно, что подобное «ограничение» рабочих часов может достигаться как с помощью физической невозможности продолжать работу (см. пример выше), так и из-за особенностей условий труда. Один из информантов (Антон, 22 года, менеджер курирования культурных учреждений, не женат (есть девушка), детей нет) указывал на то, что ему неудобно оставаться на рабочем месте дольше положенного, поскольку уборщица не может начать свою работу, пока он не покинет офис. Таким образом, нормативные ожидания других людей, необязательно напрямую относящихся к трудовому процессу, могут ограничивать рабочие часы индивида.

Офису как физическому пространству присущи определённые правила использования, тесно связанные с трудом разных людей (охранники, уборщицы и др.). Соблюдение границ не столько собствен- 
ного, сколько чужого рабочего времени может оказать влияние на интенсивность и продолжительность труда. Интервью показали, что отсутствие раздражителей в офисе в нерабочее время способно побудить работников задержаться, чтобы не упустить возможности «наиболее продуктивно» потрудиться.

Когда кабинет уже пустой, то открывается второе дыхание, уже легче себя организовать и добить какую-то работу (Артур, 27 лет, менеджер по маркетингу и рекламе, женат, несовершеннолетний ребёнок).

Тип организационной структуры может не только способствовать появлению необходимости перерабатывать, но и формировать определённое отношение сотрудников к этим переработкам.

\section{Постфордистские организации (гетерархии)}

Компании по всему миру начинают реорганизовывать внутреннюю структуру таким образом, чтобы быть способными быстро принимать решения и внедрять инновации, в результате чего распространённой становится форма организации, которую Д. Старк называет гетерархией. Её отличительными особенностями являются высокий уровень взаимозависимости между рабочими командами и горизонтальное распределение власти [Старк 2001].

Главным ресурсом современных организаций, сформированных в виде гетерархии, являются сотрудники. Успех таких компаний, особенно тех, которые занимаются предоставлением услуг другим компаниям, полностью зависит от результата интеллектуального труда работников. Важно создать такие условия труда, которые мотивировали бы сотрудников качественно выполнять свои обязанности и задерживаться на работе в случае необходимости. Согласно Голдторпу, с помощью сложных форм трудовых контрактов можно добиться возникновения материального стимула работать больше, то есть создать условия для того, чтобы с ростом прибыли компании росла и заработная плата её сотрудников [Goldthorpe 2004].

В России сложные виды трудовых контрактов встречаются крайне редко, в основном распространены фиксированные оклады и премии. Причём премии часто носят характер «кнута»: их по умолчанию выплачивают всем, а лишение премии происходит в случае невыполнения работником своих обязанностей [Тихонова 2014]. Таким образом, материальный стимул работать больше, чем формально требуется, в российских реалиях отсутствует, что отмечалось и в интервью. Наиболее эффективных результатов способны добиться те, кто обладает внутренней мотивацией к труду. Необходимо сделать так, чтобы сотрудники получали удовольствие от самого процесса работы, разделяли цели компании, чувствовали ответственность за свой труд перед коллегами и сами стремились сделать работу хорошо. В связи с этим современные компании уделяют много внимания формированию определённой корпоративной культуры.

Вид работы, свойственный гетерархиям, подразумевающий решение нестандартных, сложных задач в рамках разнообразных проектов, нидерландские исследователи называют постфордистским [Van Echtelt et al. 2007]. Одна из важнейших характеристик работы этого типа - нацеленность на результат. В отличие от работы, связанной с рутинным интеллектуальным трудом, где нужно просто выполнить свои обязанности в срок и не ошибиться при решении типовых задач, в постфордистских организациях важно находить нестандартные и эффективные пути решения проблем клиента. Работодателю не важно, сколько времени сотрудник проведёт в офисе, насколько интенсивно он будет работать. Главное, чтобы он в срок закончил проект. 
То есть если он (Сотрудник. - Авторы.) поработает час за день, но от этого будет какой-то сверхрезультат за час, я его поощрю. Если он вместо 8 часов проработал 20, но при этом результата никакого нет, то нет... Не вижу в этом смысла (Олег, 25 лет, генеральный директор малого бизнеса, не женат (есть девушка), детей нет).

Таким образом, в постфордистских организациях решения о повышении сотрудника строятся на основе оценки его вклада в развитие компании: важны навыки, следование принципам и ценностям, принятым в компании, умение эффективно работать в команде и т. п. [Deloitte Development LLC 2016].

Поскольку и работодатели, и сами сотрудники понимают, что количественные показатели, такие как количество проработанных часов, не являются тем, что может сигнализировать о ценности работника, люди перестают мыслить в категории часов. «Нормальная» продолжительность рабочего дня отсутствует, продолжительность рабочего дня может меняться в зависимости от стадии проекта, от его сложности и объёма. То, что формально считается переработкой, воспринимается сотрудниками постфордистских организаций как норма.

Переработка, вот термин «переработка» - это естественное явление, просто потому что тебе нужно закончить в срок. Когда тебе дают проект, тебе доверяют значительно большее, чем просто операциионую работу, и, соответственно, на это ты должен времени потратить больше. Но у тебя в голове не должно возникать слово «переработка», просто потому что это проект (Никита, 21 год, стажёр (сфера деятельности: консалтинг в сфере логистики), не женат (живёт с девушкой), детей нет).

Одной из отличительных черт организаций постфордистского типа является достаточно большой уровень автономии сотрудников в распределении рабочего времени. Разрешается приходить на работу в то время, в какое удобно, зачастую предусмотрена возможность удалённой работы. Некоторые офисы работают круглосуточно, чтобы те, у кого креативное мышление просыпается по ночам, могли заняться работой в это время. Понятие «рабочее время» размывается.

Сейчас очень сильно стираются границы между офисом, домом и какими-то местами... Для моего руководства важно, чтобы я в целом справлялась < .. > Когда я беру проект, фактически этот проект начинает жить со мной, в моей голове, независимо от того, где я нахожусь (Оксана, 29 лет, руководитель проекта по внедрению информационных систем, не замужем, есть молодой человек, детей нет).

Переработка в постфордистских организациях не воспринимается сотрудниками как вынужденная. Начальство никого не заставляет задерживаться на работе дольше официально положенного времени, а порой и вовсе неодобрительно относится к переработкам, полагая, что для эффективной работы сотрудникам необходим отдых. Переработка в формальном смысле слова не приносит материальных выгод сотрудникам и не играет никакой роли в принятии начальством решений о повышении. Кроме того, недоработка по количеству часов может не иметь никаких негативных последствий для сотрудника, если он хорошо справляется со своими обязанностями. В случае высокой эффективности работника могут даже премировать или повысить, что отмечалось в интервью. Тем не менее люди добровольно задерживаются допоздна и (или) занимаются работой дома, в нерабочее время.

В интервью упоминалось, что сезонное повышение спроса со стороны клиентов на услуги компании приводит к формальным переработкам. При этом регулярные задержки в офисе, чтобы успеть с проектом в срок, не воспринимаются сотрудниками как переработка независимо от объёма и сложности стоящей перед ними задачи. Правильно распределить время и силы - одна из задач команды: 
Я не считаю это переработкой, потому что появление необходимости задержаться на работе - это оплошность команды, которая работает над проектом. Какой бы он большой ни был... Ну, должны изначально выстрочть так время, чтобы не пришлось потом дополнительно тратить время (Никита, 21 год, стажёр (сфера деятельности: консалтинг в сфере логистики), не женат, живёт с девушкой, детей нет).

Необходимость взаимодействовать с командами, которые порой могут находиться в другом городе или даже другой стране, с клиентами и подрядчиками приводит к тому, что даже в нерабочее время нужно оставаться всегда на связи: проверять почту, отвечать на деловые звонки. При этом подобная деятельность также не воспринимается самими сотрудниками как переработка.

Ямогу ответить на деловое письмо в 11 часов вечера и даже не отрефлексировать, что это работа (Оксана, 29 лет, руководитель проекта по внедрению информационных систем, не замужем (есть молодой человек), детей нет).

Таким образом, задержку на работе дольше формально требуемого времени сотрудники, занятые в такого рода компаниях, воспринимают как норму. Принципы карьерного продвижения сотрудников, при которых ключевым показателем эффективности их труда являются нестандартные и эффективные пути решения проблем клиента, приводят к тому, что работники перестают мыслить в категории часов. «Нормальная» продолжительность трудового дня отсутствует: сотрудники нацелены на результат, поэтому их рабочий день может длиться разное количество часов, которое зависит от стадии проекта, от его сложности и объёма. Тот факт, что переработка воспринимается как норма, говорит о том, что организации смогли создать определённые условия и корпоративную культуру для формирования внутренней мотивации сотрудников работать больше, чем того требует договор.

\section{Организации в форме функциональной иерархии}

Совсем иначе дело обстоит в компаниях, в которых работники занимаются рутинным интеллектуальным трудом, выполняют типовые задачи. Такие сотрудники знают наперёд, что именно и как нужно делать; существуют определённые правила работы, представления о том, что должно получиться в итоге. Компании, где наиболее распространён такой тип труда, организованы в виде функциональной иерархии.

Уровень автономии сотрудников в таких организациях достаточно низок. Зачастую контролируется время прихода в офис и ухода из него. Пути карьерного роста не вполне прозрачны: начальство руководствуется собственными принципами, принимая решение о том, кого и на каких основаниях повысить в должности. Продвижению по карьерной лестнице может способствовать не только качественное выполнение обязанностей, но и большой опыт работы в компании, хорошие отношения с начальством. О том, что такое качественное выполнение работы, судить сложно при любом типе интеллектуального труда, однако если в постфордистских организациях появляются более-менее объективные критерии эффективности, измерения вклада сотрудника в развитие компании, то там, где распространён рутинный труд, этот вклад оценивается весьма субъективно. В связи с этим в такого рода организациях переработка в формальном смысле слова способна играть роль сигнала начальству о ценности сотрудника, поскольку добровольная задержка на работе может говорить об увлечённости сотрудника работой, о его лояльности компании, старательности и т. п. [Anger 2005]. При этом на деле может возникать соревновательный презентеизм [Simpson 1998], то есть задержка на работе даже тогда, когда работы никакой не осталось, что тоже отмечалось в интервью. 
Для выполнения рутинной работы требуется более скромный человеческий капитал, чем для работы, подразумевающей выполнение нестандартных, сложных задач. В связи с этим для работодателей не составляет большого труда найти работников на свободные должностные позиции. Соответственно для кандидатов на рабочие места часто действует принцип «соглашайтесь или уходите» (take it or leave it) [Hamermesh, Pfann 1996]. Как было отмечено в интервью, порой на одного работника взваливают столько обязанностей, что их физически невозможно выполнить за восьмичасовой рабочий день, но отказаться подписывать трудовое соглашение нельзя, если не хочешь потерять работу.

Когда приходишь на работу, тебе дают должностную инструкиию, где написаны обязанности, которые нужно выполнять. Но по какому-то стечению обстоятельств в эту должностную инструкцию мне каждый год добавляли всё больше и больше обязанностей за тот же оклад < .. > Если ты хочешь остаться работать, тебе подсовывают эту должностную инструкиию, ты её подписываешь, и ты обязан выполнять то, что там написано (Ирина, 45 лет, главный специалист службы технического обеспечения, замужем, двое детей).

Просьбы начальника задержаться после работы также сложно игнорировать. Даже когда отсутствует существенная материальная выгода (информанты отмечали, что надбавки за сверхурочные часы даже если и бывают, то настолько маленькие, что не стоят потраченных усилий, а премии и без того выплачиваются всем), порой приходится соглашаться на переработку, особенно когда она вызвана сезонным повышением спроса на товар или услугу компании.

Нередко сотрудники вынуждены задерживаться на работе, чтобы просто получить подпись на документе.

Ну, бывает так: вот смотрите, времени шесть часов вечера, у меня есть документ, который мне нужно обсудить с замдиректора, с директором. Их нет... Например, они в департаменте на совещании <... $>$ Я соответственно сижу, потому что я знаю, что мне нужно подписать документ. Я понимаю, что моя задача - закрыть письма. Вот мы сидим, ждём (Владимир, 22 года, начальник отдела информации, библиографии и обслуживания, не женат, детей нет).

Одним из недостатков бюрократической структуры является сложность внедрения каких-либо изменений [Битэм 1997]. В связи с этим порой причиной переработки становится необходимость выполнять какую-либо дополнительную механическую работу, которую можно было бы выполнить гораздо быстрее, если бы в компании наличествовала определённая технология для автоматизации процесса.

Таким образом, тип организационной структуры может не только способствовать появлению необходимости перерабатывать, но и формировать некоторое отношение сотрудников к этим переработкам. То, что формально считается переработкой, сотрудники постфордистских организаций могут считать нормой, а те, кто занимается выполнением в основном типовых задач, будут воспринимать как вынужденную меру для сохранения своей должностной позиции или как особую тактику действий, нацеленную на получение долгосрочных выгод.

\section{Основные выводы и перспективы дальнейших исследований}

Представления работников о том, сколько работать «нормально», и о том, что такое переработка, выражаются не только в категории часов. Помимо формальной переработки, которая представляет собой работу сверх предусмотренного трудовым договором времени, существует и неформальная. В субъективном восприятии офисных работников она определяется как ощутимое и нежелательное нарушение 
привычного образа жизни, баланса между рабочим и личным временем, а также психологическая и физическая усталость, которая приводит к потере «вкуса к жизни».

Переработка является результатом целого ряда причин, которые можно обобщить в нескольких блоках. Итак, мотивы переработок бывают следующими: (1) экономические (обеспечение карьерного роста или стабильности); (2) социальные (например, следование нормам корпоративной культуры); (3) психологические (избегание домашних проблем); (4) институциональные условия (особенности организационной структуры).

Стоит отметить, что в выборку нашего исследования попали только информанты, проживающие и работающие в Москве, а значит, у нас не было возможности описать специфические смыслы, которые вкладываются в понятие «переработка» и её практики жителями других регионов, других типов населённых пунктов. Тем не менее анализ литературы по теме продемонстрировал, что исследовательский вопрос актуален не только для Москвы, но и для других регионов и стран [Денисова 2004; Van Bastelaer, Vaguer 2004].

Кроме того, хотя мы и пытались опросить информантов из всех теоретических категорий, в нашу выборку не попали люди пожилого возраста, имевшие опыт наёмной работы в советский период, и трудящиеся в постфордистских организациях. Следовательно, не удалось пронаблюдать то, как разрешается конфликт (и возникает ли он) при переходе из одного типа организации в другой.

Некоторые эмпирические результаты исследования могут послужить основой для дальнейшей работы. Так, в ходе сбора эмпирических данных нами был недостаточно полно учтён сюжет, который, по нашему мнению, представляет исследовательскую ценность, а именно нормативные предписания, касающиеся того, для каких категорий индивидов переработка является практикой одобряемой, а для каких считается неадекватной. В одном из интервью было обозначено, что для людей старше 40 лет перерабатывать «некрасиво», в то время как для молодых работников это является нормой, объясняется их «природой» (Олег, 25 лет, генеральный директор малого бизнеса, не женат (есть девушка), детей нет). На наш взгляд, интернализированные представления о допустимых и недопустимых рабочих практиках для индивидов разных возраста, пола и семейного положения - это то, что было упущено в проведённом качественном анализе. Сбор и анализ эмпирических данных, фокусирующийся на этой проблеме, сделал бы понимание социального феномена переработок более полным.

Зафиксированные различия в смыслах, вкладываемых в переработку женщинами и мужчинами, ожидают своего подтверждения в рамках исследовательских дизайнов, которые позволяют обеспечить репрезентативность эмпирического объекта. Количественный опрос поможет понять следующее:

- действительно ли ролевой конфликт является специфическим для работающей женщины или же ему подвержены также мужчины?

- какова доля офисных работников, сталкивающихся с проблемой выбора между семьёй и работой, и какие факторы влияют на наличие или отсутствие подобной дилеммы?

Ещё одна любопытная гипотеза, сформировавшаяся в ходе анализа интервью и нуждающаяся в количественном подтверждении или опровержении, — это возможная связь типа задач, которые выполняет работник, и типа организационной структуры, в которой он трудится, а также представлений о норме и переработке. Действительно, различающийся характер деятельности предполагает разные способы оценки качества работы и практики организации рабочего времени, которые, в свою очередь, могут быть взаимозависимыми с тем, как индивид определяет норму. 


\section{Приложение}

Таблииุа П.1

Характеристики опрошенных информантов

\begin{tabular}{|c|c|c|c|c|c|c|}
\hline Информант & Пол & $\begin{array}{c}\text { Возраст } \\
\text { (полных лет) }\end{array}$ & Должность & $\begin{array}{l}\text { Должностной статус (наличие } \\
\text { или отсутствие подчинённых) }\end{array}$ & $\begin{array}{l}\text { Семейное положе- } \\
\text { ние, наличие детей }\end{array}$ & $\begin{array}{c}\text { Длительность } \\
\text { интервью (мин) }\end{array}$ \\
\hline Анна & Ж & 23 & SMM & Нет подчинённых & $\begin{array}{c}\text { Не замужем (живёт с } \\
\text { молодым человеком), } \\
\text { детей нет }\end{array}$ & 39 \\
\hline Антон & $\mathrm{M}$ & 22 & $\begin{array}{l}\text { Менеджер курирования } \\
\text { культурных учреждений }\end{array}$ & Нет подчинённых & $\begin{array}{c}\text { Не женат (есть девуш- } \\
\text { ка), детей нет }\end{array}$ & 34 \\
\hline Артур & M & 27 & $\begin{array}{c}\text { Менеджер по маркетингу } \\
\text { и рекламе }\end{array}$ & Нет подчинённых & $\begin{array}{l}\text { Женат, несовершенно- } \\
\text { летний ребёнок }\end{array}$ & 37 \\
\hline Валентина & Ж & 25 & Ведущий специалист & Нет подчинённых & $\begin{array}{c}\text { Вдова, двое совершен- } \\
\text { нолетних детей }\end{array}$ & 53 \\
\hline Виктор & M & 25 & Программист & Нет подчинённых & Не женат, детей нет & 23 \\
\hline Владимир & M & 22 & $\begin{array}{c}\text { Начальник отдела информации, } \\
\text { библиографии и обслуживания } \\
\text { ЕЭК }\end{array}$ & Есть подчинённые & Не женат, детей нет & 35 \\
\hline Евгения & Ж & 24 & $\begin{array}{c}\text { Занимается организацией марке- } \\
\text { тинговых исследований }\end{array}$ & Есть подчинённые & Не замужем, детей нет & 23 \\
\hline Елена & Ж & 32 & Креативный директор & Есть подчинённые & $\begin{array}{c}\text { Разведена, несовер- } \\
\text { шеннолетний ребёнок }\end{array}$ & 45 \\
\hline Илья & M & 23 & $\begin{array}{c}\text { Специалист в департаменте } \\
\text { продаж }\end{array}$ & Нет подчинённых & Не женат, детей нет & 44 \\
\hline Ирина & Ж & 45 & $\begin{array}{c}\text { Главный специалист службы } \\
\text { технического обеспечения }\end{array}$ & Нет подчинённых & $\begin{array}{l}\text { Замужем, двое детей } \\
\text { (совершеннолетний и } \\
\text { несовершеннолетний) }\end{array}$ & 56 \\
\hline Ксения & Ж & 19 & $\begin{array}{l}\text { Ведущий специалист } \\
\text { по поддержке продаж }\end{array}$ & Нет подчинённых & Не замужем, детей нет & 39 \\
\hline Марина & Ж & 26 & $\begin{array}{c}\text { Специалист } \\
\text { по бренд-менеджменту }\end{array}$ & Нет подчинённых & Не замужем, детей нет & 33 \\
\hline Марина & Ж & 48 & $\begin{array}{c}\text { Заместитель генерального } \\
\text { директора }\end{array}$ & Есть подчинённые & $\begin{array}{c}\text { Разведена, совершен- } \\
\text { нолетний ребенок }\end{array}$ & 34 \\
\hline
\end{tabular}


Таблица П.1. Окончание

\begin{tabular}{|c|c|c|c|c|c|c|}
\hline Информант & Пол & $\begin{array}{c}\text { Возраст } \\
\text { (полных лет) }\end{array}$ & Должность & $\begin{array}{l}\text { Должностной статус (наличие } \\
\text { или отсутствие подчинённых) }\end{array}$ & $\begin{array}{l}\text { Семейное положе- } \\
\text { ние, наличие детей }\end{array}$ & $\begin{array}{r}\text { Длительность } \\
\text { интервью (мин.) }\end{array}$ \\
\hline Мария & Ж & 27 & $\begin{array}{c}\text { Предприниматель, ранее - спе- } \\
\text { циалист по маркетингу }\end{array}$ & Есть подчинённые & Замужем, детей нет & 48 \\
\hline Наталья & Ж & 45 & Помощник директора & Есть подчинённые & $\begin{array}{c}\text { Замужем, совершен- } \\
\text { нолетний ребёнок }\end{array}$ & 43 \\
\hline Никита & M & 21 & $\begin{array}{c}\text { Стажёр (консалтинг в сфере логи- } \\
\text { стики) }\end{array}$ & Нет подчинённых & $\begin{array}{c}\text { Не женат (живёт с } \\
\text { девушкой), детей нет }\end{array}$ & 114 \\
\hline Оксана & Ж & 29 & $\begin{array}{c}\text { Руководитель проекта по внедре- } \\
\text { нию информационных систем в } \\
\text { сферу образования }\end{array}$ & Есть подчинённые & Не замужем, детей нет & 62 \\
\hline Олег & M & 25 & $\begin{array}{c}\text { Генеральный директор малого } \\
\text { бизнеса }\end{array}$ & Есть подчинённые & $\begin{array}{c}\text { Не женат (есть девуш- } \\
\text { ка), детей нет }\end{array}$ & 34 \\
\hline Ольга & Ж & 60 & Специалист по сельхозпереписи & Нет подчинённых & $\begin{array}{c}\text { Замужем, совершен- } \\
\text { нолетний ребёнок }\end{array}$ & 29 \\
\hline Светлана & Ж & 34 & Менеджер в сфере недвижимости & Нет подчинённых & $\begin{array}{l}\text { Замужем, несовер- } \\
\text { шеннолетний ребёнок }\end{array}$ & 17 \\
\hline Тимур & M & 34 & Заместитель начальника отдела & Есть подчинённые & $\begin{array}{l}\text { Женат, несовершенно- } \\
\text { летний ребёнок }\end{array}$ & 34 \\
\hline Юлия & Ж & 32 & Заведующая общежитием & Есть подчинённые & $\begin{array}{l}\text { Замужем, несовер- } \\
\text { шеннолетний ребёнок }\end{array}$ & 32 \\
\hline
\end{tabular}




\section{Литература}

Адамчук В. В., Ромашов О. В., Сорокина М. Е. 1999. Экономика и соииология труда. Учебник для вузов. М.: ЮНИТИ.

Алёшина Ю. Е., Лекторская Е. В. 1983. Ролевой конфликт работающей женщины. Вопросы психологии. 5: 80-88.

Битэм Д. 1997. Бюрократия. Сочуиологический журнал. 4: 165-185.

Вознесенская В. А. 1958. Экономические воззрения великих соџиалистов-утопистов Запада. М.: Соцэкгиз.

Гусов К. Н. (ред.) 2008. Право человека на жизнь и гарантии его реализащии в сфере труда и сощиального обеспечения. Материалы Международной научно-практической конференции. М.: Проспект.

Грановеттер М. 2002. Экономическое действие и социальная структура: проблема укоренённости. Экономическая сочиология. 3 (3): 44-58. URL: https://ecsoc.hse.ru/2002-3-3.html (дата обращения: 15.01.2017).

Денисова Ю. С. 2004. Трудовые перегрузки как тенденция в рабочем процессе. Социологические исследования. 5: 100-107.

Егоршин А. П. 2006. Мотивация трудовой деятельности. М.: Инфра-М.

Ильин Е. П. 2011. Работа и личность. Трудоголизм, перфекционизм, лень. СПб.: Питер.

Кузьминов Я., Радаев В., Яковлев А., Ясин Е. 2005. Институты: от заимствования к выращиванию. Boпросы экономики. 5: 5-27.

Куприянова 3. В. 1993. Трудовая мотивация. Экономические и сочиальнье перемень: мониторинг общественного мнения. 6: 32-36.

Ловаков А. В. 2012. Трудоголизм: понятие, методики измерения, предикторы и последствия. Организаичионная психология. 4: 28-42.

Магун В. С. 1998. Российские трудовые ценности: Идеология и массовое сознание. Мир России. 4: 113-144.

Маркс К. 1960. Инструкиия делегатам Временного Центрального совета по отдельным вопросам. Маркс К., Энгельс Ф. Соч.: В 50 т. Изд. 2-е. Т. 16. М.: Политиздат; 194-203.

Новый англо-русский толковый словарь по менеджменту и экономике труда. URL: http://slovar-vocab. com/english-russian/new-management-work-economics-vocab/overemployment-1128690.html (дата обращения: 15.01.2017).

Одинцова М. И. 2007. Институциональная экономика. М.: Изд. дом ВШЭ.

Поланьи К. 2002. Экономика как институционально оформленный процесс. Экономическая социология. 3 (2): 62-73. URL: https://ecsoc.hse.ru/2002-3-2.html (дата обращения: 15.01.2017). 
Ромашов О. В. 2001. Социология труда. Учебное пособие. М.: Гардарика.

Соловьёва С. В. 2013. Законодательное поощрение «трудоголизма» в России. Вестник Нижегородского университета им. Н. И. Лобачевского. 4 (1): 299-302.

Старк Д. 2001. Гетерархия: неоднозначность активов и организация разнообразия в постсоциалистических странах. Экономическая сочииология. 2 (2): 115-132. URL: https://ecsoc.hse.ru/2001-2-2.html (дата обращения: 15.01.2017).

Стребков Д. О., Шевчук А. В. 2009. Фрилансеры в информационной экономике: как россияне осваивают новые формы организации труда и занятости (по результатам Первой всероссийской переписи фрилансеров). Препринт WP4/2009/03. Серия WP4. Социология рынков. М.: Изд. дом ВШЭ. URL: https:// www.hse.ru/data/2010/05/05/1216427048/WP4_2009_03-\%20\%D0\%B8\%D1\%81\%D0\%BF\%D1\%80. pdf (дата обращения: 1.01.2017).

Структура занятых в экономике по фактической продолжительности рабочей недели. Федеральная служба государственной статистики. URL: http://www.gks.ru/bgd/regl/b14_61/IssWWW.exe/Stg/4-02. doc (дата обращения: 15.01.2017).

Тихонова Н. Е. 2014. Социальная структура России: теории и реальность. М.: Новый хронограф.

Томин Л. В. 2014. Современные политические конфликты: постструктуралистский анализ. СПб.: СПбГУП.

Трудовой кодекс Российской Федерации. 2016. Консультант Плюс. URL: http:/www.consultant.ru/ document/cons_doc_law_34683/(дата обращения: 15.01.2017).

Шевчук А. В. 2002. Постфордистские концепции как исследовательская программа. Экономическая социология. 3 (2): 46-61. URL: https://ecsoc.hse.ru/2002-3-2.html (дата обращения: 15.01.2017).

Шкаратан О. И. 2003. Русская культура труда и управления. Общественные науки и современность. 1: $30-54$.

Akerlof G. A. 1984. Gift Exchange and Efficiency-Wage Theory: Four Views. American Economic Review. 74 (2): 79-83.

Anger S. 2005. Working Time as an Investment? The Effects of Unpaid Overtime on Wages, Promotions and Layoffs. SFB 649 Discussion Papers SFB649DP2005-032, Sonderforschungsbereich 649. Berlin, Germany: Humboldt University.

Anger S. 2008. Overtime Work as a Signaling Device. Scottish Journal of Political Economy. 55 (2): 167189.

Babbar S., Aspelin D. J. 1998. The Overtime Rebellion: Symptom of a Bigger Problem? Academy of Management Executive. 12 (1): 68-76.

Bell D. N. F., Hart R. A. 1999. Unpaid Work. Economica. 66 (262): 271-290.

Bell L., Freeman R. B. 2001. The Incentive for Working Hard. Explaining Hours Worked Differences in the US and Germany. Labour Economics. 8: 181-202. 
Böheim R., Taylor M. P. 2004. Actual and Preferred Working Hours. British Journal of Industrial Relations. 41 (1): 149-166.

Booth A. L., Francesconi M., Frank J. 2003. A Sticky Floors Model of Promotion, Pay and Gender. European Economic Review. 47 (2): 295-322.

Bowles S., Park Y. 2005. Emulation, Inequality, and Work Hours: Was Thorsten Veblen Right? The Economic Journal. 115 (507): 397-412.

Bozionelos N. 2004. The Big Five of Personality and Work Involvement. Journal of Managerial Psychology. 19: 69-81.

Burke R. J., Davis R. A., Flett G. L. 2008. Workaholism Types, Perfectionism and Work Outcomes. The Journal of Industrial Relations and Human Resources. 10: 30-40.

Deloitte Development LLC. 2016. The New Organization: Different by Design. Global Human Capital Trends 2016. Deloitte University Press. URL: https:/www2.deloitte.com/content/dam/Deloitte/be/Documents/ human-capital/gx-dup-global-human-capital-trends-2016.pdf (дата обращения 15.01.2017).

Duesenberry J. S. 1949. Income, Savings and the Theory of Consumer Behavior. Cambridge: Harvard University Press.

Fama E. F. 1991. Time, Salary, and Incentive Payoffs in Labor Contracts. Journal of Labor Economics. 9 (1): $25-44$.

Golden L. 2009. A Brief History of Long Work Time and the Contemporary Sources of Overwork. Journal of Business Ethics. 84 (2): 217-227.

Golden L., Gebreselassie T. 2007. Overemployment Mismatches: The Preference for Fewer Work Hours. Monthly Labor Review. 130 (1): 18-37.

Goldthorpe J. H. 2004. The Economic Basis of Social Class. London: Centre for Analysis of Social Exclusion.

Hamermesh D. S., Pfann G. A. 1996. Adjustment Costs in Factor Demand. Journal of Economic Literature. 34 (3): 1264-1292.

Hochschild A. R. 1997. The Time Bind. When Work Becomes Home and Home Becomes Work. New York: Metropolitan Books.

Jirjahn U. 2008. On the Determinants of Shift Work and Overtime Work: Evidence from German Establishment. British Journal of Industrial Relations. 46 (1): 133-168.

Liang Y., Chu C. 2009. Personality Traits and Personal and Organizational Inducements: Antecedents of Workaholism. Social Behavior and Personality. 37: 645-660.

Mazzetti G., Schaufeli W. B., Guglielmi D. 2014. Are Workaholics Norn or Made? Relations of Workaholism with Person Characteristics and Overwork Climate. International Journal of Stress Management. 21 (3): 227-254. 
Ng T. W. H., Sorensen K., Feldman D. 2007. Dimensions, Antecedents, and Consequences of Workaholism: A Conceptual Integration and Extension. Journal of Organizational Behavior. 28: 111-136.

Pannenberg M. 2005. Long-Term Effects of Unpaid Overtime: Evidence for West Germany. Scottish Journal of Political Economy. 52 (2): 177-193.

Robinson B. E. 2000. Workaholism: Bridging the Gap Between Workplace, Sociocultural, and Family Research. Journal of Employment Counseling. 37: 31-47.

Schor J. B. 1992. The Overworked American. The Unexpected Decline of Leisure. New York: Basic Books.

Shaw K. L. 1989. Life Cycle Labor Supply with Human Capital Accumulation. International Economic Review. 30 (2): 431-456.

Simpson R. 1998. Presenteeism, Power and Organisational Change: Long Hours as a Career Barrier and the Impact on the Working Lives of Women Managers. British Journal of Management. 9 (1): 471-522.

Snir R., Harpaz I. 2006. The Workaholism Phenomenon: A Cross-National Perspective. Career Development International. 11 (5): 374-393.

Stark O., Tanajewski L. 2008. How and Why the Incomes of Others Can Shape the Supply of Overtime Work. Ekonomista. 5: 593-606.

Van Bastelaer A., Vaguer C. 2004. Working Times: Statistics in Focus: Population and Living Conditions. Eurostat, Luxembourg.

Van Echtelt P. et al. 2007. The Puzzle of Unpaid Overtime: Can the Time-Greediness of Post-Fordist Work be Explained? In: Van der Lippe T., Peters P. (eds). Competing Claims in Work and Family Life. Cheltenham: Edward Elgar Publishing. P. 125-142.

Van Echtelt P. et al. 2009. Post-Fordist Work: A Man's World? Gender and Working Overtime in the Netherlands. Gender and Society. 23 (2): 188-214.

Van Echtelt P. E., Glebbeek A. C., Lindenberg S. M. 2006. The New Lumpiness of Work: Explaining the Mismatch between Actual and Preferred Working Hours'. Work, Employment and Society. 20 (3): 493512.

Veblen T. 1899. The Theory of Leisure Class. New York: Modern Library. 


\section{DEBUT STUDIES}

\section{Elena Beylina, Daria Kanter, Alexander Klementev, Nadezda Lyalina Motives and Institutional Conditions of Overwork: Evidence from Moscow Office Workers}

BEYLINA, Elena - BA Student, Department of Sociology, Faculty of Social Sciences; Research Assistant, Laboratory for Studies in Economic Sociology, National Research University Higher School of Economics. Address: 20 Myasnitskaya str., Moscow, 101000, Russian Federation.

\section{Email: lenabelina@bk.ru}

KANTER, Daria - BA Student, Department of Sociology, Faculty of Social Sciences; Research Assistant, International Laboratory for Education Policy Analysis, Institute of Education, National Research University Higher School of Economics. Address: 20 Myasnitskaya str., Moscow, 101000, Russian Federation.

\section{Email: dariakanter@gmail.com}

KLEMENTEV, Aleksander - BA Student, Department of Sociology, Faculty of Social Sciences; Research Assistant, International Laboratory for Education Policy Analysis, Institute of Education, National Research University Higher School of Economics. Address: 20 Myasnitskaya str., Moscow, 101000, Russian Federation.

Email: aaklementev@edu.hse.ru

LYALINA, Nadezda - BA Student, Department of Sociology, Faculty of Social Sciences; Research Assistant, International Laboratory for Education Policy Analysis, Institute of Education, National Research University Higher School of Economics. Address: 20 Myasnitskaya str., Moscow, 101000, Russian Federation.

Email: Iyalinanadya@mail.ru

\section{Abstract}

The paper examines the phenomenon of office workers' overwork. Statistical data demonstrates that modern Russians tend to work more than 40 hours a week, thereby exceeding the legal time allowance that traces its roots back to a period when largescale manual labor was the norm. Increasing proportions of tertiary and quaternary sectors in the Russian economy suggests that the "normal" 40-hour work week is a redundant constraint and workers perceive the "norm" differently. According to the existing literature, overwork can reflect a worker's personality traits, and institutional or economic changes.

In the research article, an analysis of the motives of overwork is provided. Also, evidence of the differences in perceptions of what constitutes a "normal" work day and mental borders between work and overwork is presented.

It appears that employees perceive overwork not only as overtime work (the number of hours that they work in addition to their contractual hours), it can also be understood as a work-life imbalance, undesirable dramatic change in lifestyle due to the demands of work, and a psychological and/or physical fatigue that can lead to the loss of a "zest for life."

The following motives were identified: economic (working additional hours for career advancement, salary growth, or at least job security in the future), social (adherence to corporate norms and values), and psychological (escaping from family problems). Special attention was paid to the analysis of institutional working conditions (organizational characteristics) which can lead to overwork.

Keywords: overwork; overwork motives; overwork perception; corporate culture; labor relations; labor sociology; office workers.

\section{Acknowledgements}

Authors express special gratitude to the research advisor Maxim Markin for help and useful comments at all stages of the research. 


\section{References}

Adamchuk V. V., Romashov O. V., Sorokina M. E. (1999) Ekonomika i sotsiologiya truda: uchebnik dlya vuzov [Economics and Sociology of Labor: University Textbook], Moscow: UNITY (in Russian).

Akerlof G. A. (1984) Gift Exchange and Efficiency-Wage Theory: Four Views. American Economic Review, vol. 74, no 2, pp. 79-83.

Aleshina Y. E., Lektorskaya E. V. (1983) Rolevoy konflikt rabotayushchey zhenshchiny [The Role Conflict of a Working Woman]. Voprosy psikhologii, no 5, pp. 80-88 (in Russian).

Anger S. (2005) Working Time as an Investment? The Effects of Unpaid Overtime on Wages, Promotions and Layoffs. SFB 649 Discussion Papers SFB649DP2005-032, Sonderforschungsbereich 649, Berlin, Germany: Humboldt University.

Anger S. (2008) Overtime Work as a Signaling Service. Scottish Journal of Political Economy, vol. 55, no 2, pp. 167-189.

Babbar S., Aspelin D. J. (1998) The Overtime Rebellion: Symptom of a Bigger Problem? Academy of Management Executive, vol. 12, no 1, pp. 68-76.

Bell D. N. F., Hart R. A. (1999) Unpaid Work. Economica, vol. 66, no 262, pp. 271-290.

Bell L., Freeman R. B. (2001) The Incentive for Working Hard. Explaining Hours Worked Differences in the US and Germany. Labour Economics, no 8, pp. 181-202.

Bitehm D. (1997) Byurokratiya [Bureaucracy]. Sotsiologicheskiy zhurnal, no 4, pp. 165-185 (in Russian).

Böheim R., Taylor M. P. (2004) Actual and Preferred Working Hours. British Journal of Industrial Relations, vol. 41, no 1, pp. 149-166.

Booth A. L., Francesconi M., Frank J. (2003) A Sticky Floors Model of Promotion, Pay and Gender. European Economic Review, vol. 47, no 2, pp. 295-322.

Bowles S., Park Y. (2005) Emulation, Inequality, and Work Hours: Was Thorsten Veblen Right? The Economic Journal, vol. 115, no 507, pp. 397-412.

Bozionelos N. (2004) The Big Five of Personality and Work Involvement. Journal of Managerial Psychology, no 19 , pp. 69-81.

Burke R. J., Davis R. A., Flett G. L. (2008) Workaholism Types, Perfectionism and Work Outcomes. The Journal of Industrial Relations and Human Resources, no 10, pp. 30-40.

Deloitte Development LLC. 2016. The New Organization: Different by Design. Global Human Capital Trends 2016. Deloitte University Press. Available at https:/www2.deloitte.com/content/dam/Deloitte/be/Documents/human-capital/gx-dup-global-human-capital-trends-2016.pdf (accessed 15 January 2017).

Denisova Y. S. (2004) Trudovye peregruzki kak tendentsiya v rabochem protsesse [Labor Overload as a Trend in the Working Process]. Sotsiologicheskie issledovaniya, no 5, pp. 100-107 (in Russian). 
Duesenberry J. S. (1949) Income, Savings and the Theory of Consumer Behavior, Cambridge: Harvard University Press.

Egorshin A. P. (2006) Motivatsiya trudovoy deyatel'nosti [Motivation of Labour Activity], Moscow: Infra-M (in Russian).

Fama E. F. (1991) Time, Salary, and Incentive Payoffs in Labor Contracts. Journal of Labor Economics, vol. 9, no 1, pp. 25-44.

Golden L. (2009) A Brief History of Long Work Time and the Contemporary Sources of Overwork. Journal of Business Ethics, vol. 84, no 2, pp. 217-227.

Golden L., Gebreselassie T. (2007) Overemployment Mismatches: The Preference for Fewer Work Hours. Monthly Labor Review, vol. 130, no 1, pp. 18-37.

Goldthorpe J. H. (2004) The Economic Basis of Social Class, London: Centre for Analysis of Social Exclusion.

Granovetter M. (2002) Ekonomicheskoe deystvie i sotsial'naya struktura: problema ukorenennosti [Economic Action and Social Structure: The Problem of Embeddedness]. Journal of Economic Sociology = Ekonomicheskaya sotsiologiya, vol.3,no3,pp.44-58.Available at https://ecsoc.hse.ru/data/2011/12/08/1208205035/ ecsoc_t3_n3.pdf\#page $=44$ (accessed 15 January 2017) (in Russian).

Gusov K. N. (ed.) (2008) Pravo cheloveka na zhizn'i garantii ego realizatsii v sfere truda $i$ sotsial'nogo obespecheniya [The Human Right to Life and the Guarantee of its Implementation in the Field of Labor and Social Security]. Materialy Mezhdunarodnoy nauchno-prakticheskoy konferentsii [International Conference Materials], Moscow: Prospekt (in Russian).

Hamermesh D. S., Pfann G. A. (1996) Adjustment Costs in Factor Demand. Journal of Economic Literature, vol. 34, no 3, pp. 1264-1292.

Hochschild A. R. (1997) The Time Bind. When Work Becomes Home and Home Becomes Work, New York: Metropolitan Books.

Il'in E. P. (2011) Rabota i lichnost'. Trudogolizm, perfektsionizm, len' [Work and Individual. Workaholism, Perfectionism, Laziness], Saint-Petersburg: Piter (in Russian).

Jirjahn U. (2008) On the Determinants of Shift Work and Overtime Work: Evidence from German Establishment. British Journal of Industrial Relations, vol. 46, no 1, pp. 133-168.

Kuz'minov Y. A., Radaev V., Yakovlev A., Yasin E. (2005) Instituty: ot zaimstvovaniya k vyrashchivaniyu [Institutions: From Adopting to Cultivating]. Voprosy ekonomiki, no 5, pp. 5-27 (in Russian).

Kupriyanova Z. V. (1993) Trudovaya motivatsiya [Labour Motivation]. Ekonomicheskie i sotsial'nye peremeny: monitoring obshchestvennogo mneniya, no 6, pp. 32-36 (in Russian).

Liang Y., Chu C. (2009) Personality Traits and Personal and Organizational Inducements: Antecedents of Workaholism. Social Behavior and Personality, no 37, pp. 645-660. 
Lovakov A. V. (2012) Trudogolizm: ponyatie, metodiki izmereniya, prediktory i posledstviya [Workaholism: Concept, Measurement Method, Predictors and Consequences]. Organizacionnaya psihologiya, no 4, pp. 28-42 (in Russian).

Magun V. S. (1998) Rossiyskie trudovye ysennosti: Ideologiya i massovoe soznanie [Russian Labour Values. Ideology and Mass Consciousness]. Mir Rossii, no 4, pp. 113-144 (in Russian).

Marx K. (1960) Instruktsiya delegatam Vremennogo Tsentral'nogo Soveta po otdel'nym voprosam [Instructions for the Delegates of the Provisional General Council: The Different Questions]. Marx K., Engels F. Sochineniya [Collection of Works]: 50 vols, 2nd ed. Vol. 16, Moscow: Politizdat, pp. 194-203 (in Russian).

Mazzetti G., Schaufeli W. B., Guglielmi D. (2014) Are Workaholics Born or Made? Relations of Workaholism with Person Characteristics and Overwork Climate. International Journal of Stress Management, vol. 21, no 3, pp. 227-254.

Ng T. W. H., Sorensen K., Feldman D. (2007) Dimensions, Antecedents, and Consequences of Workaholism: A Conceptual Integration and Extension. Journal of Organizational Behavior, no 28, pp. 111-136.

Novyy anglo-russkyj tolkovyy slovar' po menedzhmentu i ekonomike truda [New English-Russian Dictionary of Management and Labour Economics. Institutional Economics]. Available at http://slovar-vocab. com/english-russian/new-management-work-economics-vocab/overemployment-1128690.html (accessed 15 January 2017) (in Russian).

Odintsova M. I. (2007) Institutsional'naya Ekonomika [Institutional Economics], Moscow: HSE Publishimg House (in Russian).

Pannenberg M. (2005) Long-Term Effects of Unpaid Overtime: Evidence for West Germany. Scottish Journal of Political Economy, vol. 52, no 2, pp. 177-193.

Polanyi K. (2002) Ekonomika kak institutsional'no oformlennyy process [The Economy as Instituted Process]. Journal of Economic Sociology = Ekonomicheskaya sotsiologiya, vol. 3, no 2, pp. 62-73. Available at https://ecsoc.hse.ru/2002-3-2.html (accessed 15 January 2017) (in Russian).

Robinson B. E. (2000) Workaholism: Bridging the Gap between Workplace, Sociocultural, and Family Research. Journal of Employment Counseling, no 37, pp. 31-47.

Romashov O. V. (2001) Sotsiologiya truda [Sociology of Labour]. Uchebnoe posobie, Moscow: Gardarika (in Russian).

Schor J. B. (1992) The Overworked American. The Unexpected Decline of Leisure, New York: Basic Books.

Shaw K. L. (1989) Life Cycle Labor Supply with Human Capital Accumulation. International Economic Review, vol. 30, no 2, pp. 431-456.

Shevchuk A. (2002) Postfordistskie konseptsii kak issledovatel'skaya programma [Post-Fordist Concepts as a Research Program]. Journal of Economic Sociology = Ekonomicheskaya sotsiologiya, vol. 3, no 2, pp. 4661. Available at https://ecsoc.hse.ru/2002-3-2.html (accessed 15 January 2017) (in Russian). 
Shkaratan O. I. (2003) Russkaya kul'tura truda i upravleniya [Russian Work and Management Culture]. Obshchestvennye nauki i sovremennost', no 1, pp. 30-54 (in Russian).

Simpson R. (1998) Presenteeism, Power and Organisational Change: Long Hours as a Career Barrier and the Impact on the Working Lives of Women Managers. British Journal of Management, vol. 9, no 1, pp. 471-522.

Snir R., Harpaz I. (2006) The Workaholism Phenomenon: A Cross-National Perspective. Career Development International, vol. 11, no 5, pp. 374-393.

Solov'eva S. V. (2013) Zakonodatel'noe pooshchrenie "trudogolizma” v Rossii [Legislative Encouragement of "Workaholism" in Russia]. Vestnik Nizhegorodskogo universiteta im. N. I. Lobachevskogo, vol. 4, no 1, pp. 299-302 (in Russian).

Stark D. (2001) Geterarkhiya: neodnoznachnost' aktivov i organizatsiya raznoobraziya v postsocialisticheskih stranakh [Recombinant Property in East European Capitalism]. Journal of Economic Sociology = Ekonomicheskaya sotsiologiya, vol. 2, no 2, pp. 115-132. Available at: https://ecsoc.hse.ru/2001-2-2.html (accessed 15 January 2017) (in Russian).

Strebkov D. O., Shevchuk A. V. (2009) Frilansery v informatsionnoy Ekonomike: kak rossiyane osvaivayut novye formy organizatsii truda i zanyatosti (po rezul'tatam Pervoy vserossiyskoy perepisi frilanserov) [Freelancers in the Information Economy: How Russians Adopt New Forms of Work Organization and Employment (Evidence from the First All-Russian Freelancers' Census)]. Working paper WP4/2009/03, Moscow: HSE Publishing House (in Russian).

Struktura zanyatykh v ekonomike po fakticheskoy prodolzhitel'nosti rabochey nedeli [The Structure of Employment in the Economy for the Actual Duration of the Working Week]. Federal'naya sluzhba gosudarstvennoy statistiki. Available at http://www.gks.ru/bgd/regl/b14_61/IssWWW.exe/Stg/4-02.doc (accessed 15 January 2017) (in Russian).

Stark O., Tanajewski L. 2008. How and Why the Incomes of Others Can Shape the Supply of Overtime Work. Ekonomista (The Economist), no 5, pp. 593-606.

Tikhonova N. E. (2014) Sotsial'naya struktura Rossii: teorii i real'nost' [Social Structure in Russia: Theory and Reality], Moscow: Novyy khronograf (in Russian).

Tomin L. V. 2014. Sovremennye politicheskie konflikty: poststrukturalistskiy analiz. [Contemporary Political Conflicts, Post-Structuralistic Analysis], Saint Petersburg: University of the Humanities and Social Sciences at Saint Petersburg (in Russian).

Trudovoy kodeks Rossiyskoy Federatsii [Compensation of Overtime Work] (2016) Konsul'tantPlyus. Available at: http://www.consultant.ru/document/cons_doc_law_34683/ (accessed 15 January2017) (in Russian).

Van Bastelaer A., Vaguer C. (2004) Working Times: Statistics in Focus: Population and Living Conditions. Eurostat, Luxembourg

Van Echtelt P., Glebbeek A., Lewis S., Lindenberg S. (2009) Post-Fordist Work: A Man's World? Gender and Working Overtime in the Netherlands. Gender and Society, vol. 23, no 2, pp. 188-214. 
Van Echtelt P., Glebbeek A., Wielers R., Lindenberg S. (2007) The Puzzle of Unpaid Overtime: Can the TimeGreediness of Post-Fordist Work be Explained? Competing Claims in Work and Family Life (eds. T. Van der Lippe, P. Peters), Cheltenham: Edward Elgar Publishing, pp. 125-142.

Van Echtelt P. E., Glebbeek A. C., Lindenberg S. M. (2006) The New Lumpiness of Work: Explaining the Mismatch between Actual and Preferred Working Hours'. Work, Employment and Society, vol. 20, no 3, pp. 493-512.

Veblen T. (1899) The Theory of Leisure Class, New York: Modern Library.

Voznesenskaya V. A. (1958) Ekonomicheskie vozzreniya velikikh sotsialistov-utopistov Zapada [Economic Views of the Great Socialist-Utopianinsts], Moscow: Sotsekgiz (in Russian).

Citation: Beylina E., Kanter D., Klementev A., Lyalina N. (2017) Motivy i institutsional'nye usloviya pererabotok (na primere ofisnykh sluzhashchikh goroda Moskvy) [Motives and Institutional Conditions of Overwork: Evidence from Moscow Office Workers]. Journal of Economic Sociology = Ekonomicheskaya sotsiologiya, vol. 18, no 1, pp. .51-79. Available at: https://ecsoc.hse.ru/2017-18-1.html (in Russian). 


\section{ПРОФЕССИОНАЛЬНЫЕ ОБЗОРЫ}

\section{Г. Е. Новиков}

\section{Очерк истории потребительского кредита}

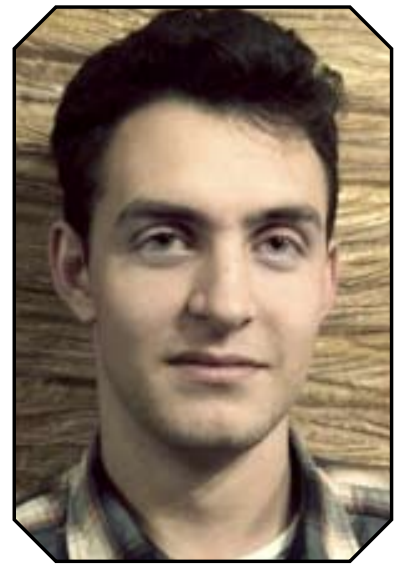

нОВикОВ Глеб

Евгеньевич -

студент бакалаврской

программы

«Социология»

факультета социальных

наук, лаборант

Лаборатории экономико-

социологических

исследований

Национального

исследовательского

университета «Высшая

школа экономики».

Адрес: 101000,

Россия, г. Москва,

ул. Мясницкая, д. 20.

Email: nov.gleb.evg@ yandex.ru
Данный обзор представляет характеристику и анализ исторических форм потребительского кредитования. Теоретической базой обзора является культурная и сочиальная история потребительского кредита ${ }^{1}$ - новое междисциплинарное направление, предлагающее альтернативный подход к изучению и пониманию роли, которую кредит в разных странах $и$ в разные исторические периоды играет в жизни людей. В рамках этого подхода в центре внимания оказываются тесные связи между кредитом и отношениями в сообществе, изменения повседневных практик, вызванные распространением потребительского кредитования, и сдвиги в восприятии кредита, его принятии или отторжении. Особый акцент делается на выявлении различий между формами кредитования в разных странах и в разные исторические периоды. Культурная и сочиильная история кредита представляется наиболее удачным подходом для рассмотрения форм потребительского кредитования в их исторической изменчивости.

Очертив проблемное поле истории кредита, автор рассматривает институциональные условия формирования современных форм кредитования: законодательство, более или менее строго регулировавщее долговые отношения, и уже существовавшие формы кредита, такие как ломбарды, малье займы, рассрочка, семейные займы и кредиты по «открытой книге». Затем анализируется развитие потребительского кредита в США, где ключевыми прочессами были легализация и легитимация малых займов, распространение продаж в рассрочку и эволюиия форм кредитного учёта, и в Европе, где наибольший интерес представляют чековые системы кредитования (особенно реализованная Provident Clothing and Supply Company в Великобритании), не имевшие аналогов в Америке. Далее уделяется внимание критике кредита, возникающей на протяжении его развития. Основными направлениями противостояния кредиту были критика с этических позищий и критика кредита как проявления капитализма и американской экспансии. В заключении обосновывается значимость исследований по истории кредита как для выстраивания экономических и сочиологических аргументов в этой области, так и для понимания сложности и многогранности путей, приведших к формированию тех институтов, которые сегодня называются потребительским кредитованием.

Ключевые слова: потребительский кредит; история кредита; культурная история; социальная история; сообщество; кредитный учёт; финансовые компании; чековые системы кредитования.

\footnotetext{
В рамках данного обзора словосочетания «культурная и социальная история потребительского кредита», «культурная и социальная история кредита» и «история кредита» используются как синонимы.
} 


\section{1. Введение}

Потребительское кредитование является предметом дискуссий не только в повседневной жизни, но и в академическом сообществе. В первой половине XX века привилегия давать экспертную оценку кредиту и его влиянию на жизнь людей принадлежала только экономистам; примерно с середины XX века к обсуждению подключились социологи. Экономисты рассматривали потребительский кредит как данность, как закономерное развитие рыночных отношений и, главным образом, анализировали его позитивное влияние на экономический рост. В противоположность им социологи видели в появлении и распространении кредита причину самых разных тревожащих изменений в современности. Список последствий развития кредитных отношений оказывается вполне катастрофичным: это и ослабление социальной структуры, и стирание «когнитивной связи» между доходом и потреблением, и безудержный рост потребления, и исчезновение этики, и увеличение эксплуатации, и рационализация повседневных практик [Marron 2009: 3-8]. Такие диаметрально противоположные интерпретации оказались возможны отчасти из-за различных базовых теоретических позиций экономики и социологии, навязывающих определённую логику рассуждения, отчасти из-за того, что эмпирический материал был сильно сконцентрирован как в пространстве, так и во времени.

С конца 1990-х гг. к исследованиям кредита обратились представители других дисциплин, стала оформляться отдельная предметная область, которая заметно обогатилась эмпирическими данными как в исторической, так и в кросскультурной перспективе, благодаря чему выяснилось, что и экономисты, и социологи слишком упрощают ситуацию потребительского кредитования, а в некоторых аспектах просто заблуждаются. Пафос истории потребительского кредита заключается в следующем: точка зрения на кредит как на сугубо экономический феномен, а на экономику как на принципиально отдельную «сферу» жизни, функционирующую по своим законам, точно так же неверна, как отнесение кредитных отношений к разрушительным проявлениям современности и противопоставление этих «экономических» отношений социальным связям и Gemeinschaft' ${ }^{2}$ в целом.

Два основных разделяемых и поддерживаемых экономистами и социологами мифа о кредите, которые стремится разрушить история кредита, это (1) миф о кредите как о «великом демократизаторе», позволяющем каждому достичь желаемого, и (2) миф об утраченной «экономической добродетели», относящейся ко времени, когда люди жили по средствам и сдерживали свои желания. Что касается первого мифа, то исполнение желаний оборачивается гораздо более мощным, чем до возникновения современных форм кредита, развитием практик бюджетирования и экономии; в то же время сами желания не являются спонтанно образующимися предпочтениями, а формируются сообществом. Заблуждением оказывается и второй миф: люди никогда не жили по средствам, и долговые отношения обнаруживаются во всех эпохах и культурах. Более того, современные формы кредитования никак нельзя назвать антисоциальными; напротив, они никогда не закрепились бы, если бы не базировались на существующих отношениях внутри сообществ [Calder 1999: 23-33; O’Connel 2009: 6-7; Meyer 2012: 231].

История потребительского кредита - достаточно молодое направление с ещё не определённой теоретической рамкой и неустоявшейся традицией рассуждения. Отсутствует и чёткая дисциплинарная принадлежность: история потребительского кредита сочетает элементы истории предпринимательства, экономической, культурной, социальной и политической истории и, кроме того, связана с масштабными теоретическими дебатами о современности, глобализации и обществе потребления. Несмотря на недостаточность фундаментальных исследований по истории кредита в отдельных странах и полное

2 Gemeinschaft (нем.) - традиционно непереводимый термин (наиболее близкие переводы на рус. яз. — «община», «сообщество»), введённый в социологию Ф. Тённисом для описания социальных отношений и образований, которые воспринимаются их участниками как органическое единство. У Тённиса этому термину противостоит понятие Gesellschaft (общество), которым описываются отношения, воспринимаемые как мыслительная конструкция. 
отсутствие работ, предлагающих широкие обобщения этой истории, получено уже немало интересных выводов. Социальная и культурная история кредита стремится ответить на вопросы о том, как в различных исторических условиях сосуществовали кредитные и реципрокные отношения, в какой степени долг и кредит были интегрирующими факторами, как менялось понимание людьми кредита и денег, какова связь между кредитом и индивидуальной свободой [Logemann 2012; Meyer 2012: 223-229; Hsu, Luckett, Vause 2015: xiv].

В данном обзоре рассматриваются основные исторические формы потребительского кредита, причины и условия их возникновения, а также препятствия их распространению и легитимации. Сначала даётся краткая характеристика институциональных условий формирования современных форм кредитования (особенности законодательства в Европе и Америке и существовавшие в XIX веке практики одалживания). Далее подробно рассматривается развитие потребительского кредитования в США и в странах Европы (главным образом в Великобритании, Франции и Германии) ${ }^{3}$. Наконец, анализируются основные способы противодействия изменениям институтов и практик кредитования. В заключении обобщается проведённый анализ и делаются выводы. В приложении приводится таблица форм кредитования, наиболее распространённых в тех или иных странах в те или иные исторические периоды.

\section{2. Институциональные условия формирования потребительского кредита}

Различные институты кредитования, которые начали формироваться с конца XIX века и были в большей или в меньшей степени похожи на современные, развивались либо на базе досовременных форм кредита, либо в противовес им.

\section{1. Законодательное регулирование}

Важно подчеркнуть, что контекст существования кредитных институтов во многом определялся законодательным регулированием. В 1545 г. король Англии Генрих VIII признал все займы (как предпринимательские, так и потребительские) под процент выше $10 \%$ ростовщичеством и запретил. Соответственно, на протяжении XVI-XVIII веков такие рынки на территории Британской империи существовали нелегально. Однако начиная с 1830 -х гг. чартистское движение в Англии смогло добиться существенных послаблений в законе о ростовщичестве, а в 1854 г. он был полностью отменен. В результате малые займы стали полностью легальными в Англии, никак не регулировались законом и развивались как свободный рынок. В США закон, устанавливающий 6\%-ную границу ростовщичества, действовал вплоть до начала XX века, и малые займы практически повсеместно считались нелегальными [Neifeld 1941: 24; Calder 1999: 114].

Ещё одним важным отличием английского законодательства от американского было различное определение прав собственности. В США товар, проданный в кредит, переходил в собственность покупателя, тогда как в Великобритании продавец продолжал формально владеть товаром до тех пор, пока кредит не будет выплачен полностью [Calder 1999: 165-166]. Этот принцип способствовал тому, что кредиторы в Великобритании чувствовали себя гораздо более свободно и могли пользоваться поддержкой закона. Кроме того, такое законодательство отчасти объясняет популярность чековой (провидентской) системы, распространившейся в Англии в начале XX века. Действительно, покупка в кредит не товаров, а чеков нивелировала риск изъятия и судебного преследования в случае неуплаты. Ситуация изме-

3 Ограничение обзора этими несколькими странами продиктовано двумя соображениями. Во-первых, потребительский кредит в своей современной форме раньше всего возник в США и там же быстрее всего распространился, а впоследствии экспансия продолжилась оттуда и в другие страны. Именно поэтому истории кредита в США уделяется особое внимание в обзоре. Во-вторых, поскольку исследования в рамках социальной и культурной истории кредита ограничиваются пока небольшим числом стран и эпох, вполне логично, что обзор сосредоточивается именно на них. 
нилась только в 1938 г. с принятием Акта о рассрочке (Hire Purchase Act): был введён запрет продавцам возвращать товары после того, как уплачена треть стоимости [Gelpi, Julien-Labruyère 2000: 131].

Немаловажную роль играла степень законодательного регулирования кредитования, отличающаяся для разных стран в разные периоды. Один из первых законов о потребительском кредитовании был принят в Германии в 1894 г. Хотя закон в большей степени отражал опасения буржуазии и стремился ограничить распространение кредита, кредитные институты продолжали развиваться, и закон отчасти даже способствовал этому, сделав их положение более легитимным, что впоследствии произошло и в Америке [Logemann 2011: 533].

Далее в обзоре внимание будет уделяться изменениям в законодательстве, которые оказали существенное влияние на практики кредитования. Если характеризовать ситуацию в самых общих чертах, то в США потребительское кредитование регулируется очень сильно, но большинство законов были приняты, когда кредитный рынок был уже весьма устойчив. Напротив, во Франции и Германии процессы регулирования и формирования рынка происходили параллельно. В Великобритании же, за некоторыми исключениями ${ }^{4}$, законодательные изменения оказывали наименьшее воздействие на развитие кредитного рынка.

\section{2. Кредит в XIX веке}

Л. Колдер выделяет пять форм займа, распространённых в США в XIX веке: ломбарды, малые займы, розничные кредиты, займы у друзей и родственников, а также ипотечные кредиты [Calder 1999: 38]. Ломбарды были широко распространены на протяжении всего XIX века; их популярность не снижалась вплоть до 1930-х гг. Однако услуги большинства из них были ориентированы на беднейшие слои населения. В качестве залога принимались в основном одежда и предметы личного пользования. В 1880-х гг. появились ломбарды, принимающие в качестве залога правовой титул имущества, а не сами вещи [Marron 2009: 20]. Малые займы также пользовались большим спросом, однако, согласно законам того времени, этот рынок был нелегальным. Малые займы давались под максимально высокий процент, клиенты запугивались тем, что о взятом кредите станет известно родственникам, видимость законности создавалась подписанием многочисленных соглашений и контрактов, а полулегальность обеспечивалась разбиением процента на «законную» часть и множество нерегистрируемых доплат и комиссий. За кредиторами прочно закрепилось прозвище «акулы-ростовщики» (loan sharks). К концу XIX века бизнес малых займов стал одним из самых развитых сетевых предприятий в Америке, несмотря на то что был фактически нелегальным: в 1900 г. сети Д. Толмана и Дж. Малхолланда включали около 160 офисов по всей стране. Розничной торговлей в кредит в основном занимались иммигранты, покупая у магазина или оптовика в кредит те товары, которые были востребованы в иммигрантской среде. Далее, используя имеющуюся сеть, коммивояжеры продавали товары по завышенной цене. Благодаря знанию языка, культуры и оказываемому им доверию они успешно вовлекали этнические и национальные сообщества в американские практики потребления. Что касается займов у членов семьи и друзей, то в этих отношениях существовал «этикет долга», определявший, у кого сколько можно одолжить, и игравший, таким образом, важную роль в повседневной экономической деятельности. Если люди среднего класса в личных займах использовали чёткие контракты и условия, то рабочие чаще обращались с ними как с дарами [Calder 1999: 42-64, 115-119].

4 Кредитный рынок был частично ответственным за высокую инфляцию в Великобритании после Второй мировой войны, что привело к попыткам регулировать его. Так, в 1952-1958 гг. Министерство торговли Великобритании (Воаrd of Trade, с 1970 г. вошло в состав Министерства торговли и промышленности) меняло законодательство о финансовых компаниях 22 раза. Однако после исследования специальной комиссии в 1974 г. был принят Акт о потребительских кредитах, снова снявший практически все ограничения [Gelpi, Julien-Labruyère 2000: 131]. 
В Великобритании XIX века кредитование было представлено главным образом ломбардами и малыми займами, причём для распространения последних специально нанятые работники (tallymen - maльманыl, таллиманы, отметчики - торговцы в кредит или в рассрочку; то же, что и credit drapers) обходили дома, продавая одежду и ткани и собирая еженедельные выплаты [Gelpi, Julien-Labruyère 2000: 126-127]. Как и в Америке, кредиторы предпочитали оказывать давление на неработающих женщин, но, в отличие от ситуации в США, в Англии у них была возможность задействовать суды для преследования неплательщиков, чем они активно пользовались [О’Connel 2012: 87]. В Германии наибольшее распространение имели «кредитные дома», продававшие в рассрочку самые разнообразные товары. Характерно, что продажа в рассрочку в Америке была ориентирована в первую очередь на сельских жителей и, по-видимому, менее распространена, чем в Германии, где она была достаточно популярна именно в городской среде [Logemann 2011: 533]. Во Франции (как и в странах Южной Европы, например, в Италии и Испании) в XIX веке преобладали так называемые monts-de-piétés («горы благочестия〉) - ломбарды, которые финансировались за счёт благотворительности и обслуживали бедных, взимая низкий процент. Однако отмечается, что, поскольку эти ломбарды управлялись муниципально, их деятельность ограничивалась множеством бюрократических процедур, и реально помочь бедным они зачастую не могли. Институт малых займов во Франции также существовал и был подвержен той же этической критике, что и американские акулы-ростовщики. Можно предположить, что займы у родственников и друзей были одной из форм долга на территории всей Европы [Gelpi, JulienLabruyère 2000: 123-125].

Важно подчеркнуть, что большинство этих форм кредитования существовали в городах, а в сельской местности (а в Америке до 1830-х гг. - повсеместно) наибольшее распространение имели так называемые кредиты «по открытой книге» (open-book credits) - неформальные договорённости продавца с покупателем, согласно которым покупатель мог взять товар, а заплатить за него спустя некоторое время; название связано с тем, что такие обязательства продавцы обычно фиксировали в специальных книгах [Calder 1999: 59; Gelpi, Julien-Labruyère 2000: 97-98].

\section{3. Развитие современных форм кредитования}

\section{1. Развитие кредита в США}

В начале XX века развитие потребительского кредита в США происходило по двум параллельным направлениям: (1) малые займы (small loans) начали контролироваться законодательством и перешли на легальную основу; (2) ещё с конца XIX века устойчиво распространялись продажи в рассрочку (installment credit).

Нелегальный рынок малых займов был впервые рассмотрен как общественная проблема Фондом Рассела Сейджа. Исследования, проведённые студентом Колумбийского университета Артуром Хэмом, послужили основой для кампании за легализацию малых займов (1909-1917 гг.). Основные направления кампании Хэма - публичная активность, поддержка благотворительных фондов и изменение законодательства. На первом этапе отделением Фонда Рассела Сейджа по кредитам помощи (Division of Remedial Loans), директором которого стал Хэм, были предприняты следующие действия: (1) судебные процессы против ряда кредиторов, нарушавших законодательство, и отзыв лицензий у некоторых из них; (2) сотрудничество с Нью-Йоркским обществом правовой помощи (защита и правовая помощь для жертв ростовщиков, организация пробных слушаний дел); (3) убеждение работодателей не применять санкции в отношении работников, попавших в долговую зависимость; (4) убеждение некоторых арендодателей не сдавать помещения ростовщикам; (5) лоббирование запрета для нелегальных кредиторов размещать рекламу своих услуг в ежедневных газетах; (6) назначение специального прокурора по случаям ростовщичества [Calder 1999: 124-128]. 
Действия Хэма привели к значительным успехам. Проблема на самом деле была выведена в публичное пространство. К концу июня 1913 г. в 24 штатах были представлены 60 законопроектов, касающихся отмены закона о ростовщичестве. Сами кредиторы при этом разделились на две категории: одни пытались блокировать введение законов и в течение нескольких лет добивались в этом успеха, тогда как другие приняли сторону Хэма и присоединились к кампании, попутно борясь за принятие более выгодного для себя законодательства.

Окончательный проект законодательства был разработан Хэмом совместно с представителями кредитных обществ помощи (remedial loan societies) и самих кредиторов. В 1917 г. законопроект Единого закона о малых займах (Uniform Small Loan Law) был представлен в четырёх штатах, утверждён в Иллинойсе, Индиане и Мэне. К 1932 г. он был введён уже в 25 штатах [Calder 1999: 130-135].

Бумом малых займов в США ознаменовались 1920-е гг. Росло число частных финансовых компаний, большинство из них входили в региональные ассоциации кредиторов.

Появление продаж в рассрочку в форме, близкой к современному потребительскому кредитованию, связано с компанией «Зингер» (Singer Corporation), которая продавала в рассрочку достаточно дорогие для того времени швейные машины. Компания была основана в 1851 г.; к 1856 г. ей удалось достичь патентного соглашения с другими производителями, и продажи резко возросли. К началу ХХ века многие производители заимствовали идею продажи в рассрочку, появились «кредитные дома» (installment houses), где большинство товаров продавалось по такой системе.

Необходимыми условиями для распространения кредита стали иммиграция (увеличение спроса на бытовые товары), урбанизация (рост символически опосредованной коммуникации) и индустриализация (подъём уровня производства), а также рост заработной платы (с 1860 г. по 1920 г. она увеличилась в два раза). Во второй половине XIX века кредит в рассрочку развивался в трёх направлениях [Calder 1999: 162-175]: (1) новые товары5; (2) новые географические регионы (ключевую роль сыграли почтовые рассылки каталогов - идея, с не меньшим успехом применённая в Великобритании более полувека спустя); (3) группы с меньшими доходами.

Ключевым рынком для экспансии кредита стал автомобильный рынок. Как кредит не распространился бы столь сильно без автомобильного рынка, так и сам рынок не расширился бы без покупок в рассрочку. В начале XX века автомобили стоили больше 1500 дол. и не были доступны большинству населения, и даже модель Т, выпущенная Генри Фордом в 1908 г., стоила 850 дол. Было весьма выгодно торговать автомобилями в кредит, однако перекупщикам для этого не хватало средств, так как производитель продавал автомобили только оптом, за полную сумму. В 1913 г. Л. Уивер основывает первую финансовую компанию по продажам, которая выступила посредником между банками, продавцами и покупателями. Компания финансирует продавцов, чтобы они смогли купить партию автомобилей, и покупателей, чтобы они могли купить автомобиль в кредит [Calder 1999: 183-190].

5 Л. Колдер выделяет три формы предоставления кредита в рассрочку [Calder 1999: 175-185]: (1) рассрочка высокого класса - на рынке действуют несколько крупных фирм; продаются таким образом в основном мебель, швейные машины и книги; большинством клиентов были наёмные рабочие и работающие по подряду; невыплаты редки, условия умеренные; (2) рассрочка низкого класса - на рынке действуют много мелких фирм; продаются самые разнообразные товары; выплаты - по нескольку долларов в неделю, цены завышены в 3-4 раза; клиенты в таком случае рекрутируются коммивояжерами: локальными (связанными с определённой социальной группой), «толкателями» (связанными с конкретными магазинами) и независимыми (занимающимися самостоятельной перепродажей); (3) недобросовестная рассрочка, производящаяся с помощью разнообразных уловок (в самом договоре или при подписании), когда кредит оформляется на очень плохих условиях и с очень завышенной ценой на товар. 
В 1928-1930 гг. в кредит продавалось 9,2\% розничных товаров (ещё 32,2\% - в открытый кредит), 60-75\% автомобилей, 80-90\% мебели, 75\% стиральных машин, 65\% пылесосов, $18-25 \%$ ювелирной продукции, 75\% радиоприёмников, 80\% граммофонов. Рассматривая социальную базу потребительского кредита в 1920-1930 гг., Л. Колдер ссылается на исследование У. Пламмера, которое показало, что кредит распространён более всего среди семей с низкими доходами, но наибольший вклад в общую задолженность вносят представители среднего класса [Calder 1999: 202-203].

В первые десятилетия XX века изменяются не только легальное положение кредита и образ жизни должников, но и практики, связанные с кредитным учётом (фиксация данных о заёмщике и о размерах и условиях кредита). В XIX веке основой предоставления кредита были личное знание потенциального заёмщика, его «репутация» и статус в локальном сообществе. В 1910-1930 гг., с распространением массового кредита, эти практики начали меняться. Можно выделить две стадии этого сдвига. На первой кредиторы пытаются формализовать знание о должниках так, чтобы оно стало идентичным личному знанию и при этом могло воспроизводиться на массовой основе (появляются кредитные бюро, собирающие и агрегирующие информацию обо всех заёмщиках и предоставляющие её кредиторам). На второй стадии изменений происходит полная рационализация учёта (вводятся идентификационные платёжные карты и отдельные записи вместо долговых книг) [Jeacle, Walsh 2002].

Во время Великой депрессии кредитные предприятия пострадали значительно меньше, чем другие отрасли. Закрылись всего 39 финансовых компаний, и клиенты менее половины всех компаний понесли убытки.

В 1930-е гг. началось распространение банковского кредита. В 1928 г. Национальный городской банк Нью-Йорка открыл первое отделение персональных займов, обслуживающее наёмных рабочих и клерков. К 1938 г. этому примеру последовали 1222 банка. Новый курс президента Ф. Рузвельта вызвал масштабные изменения в законодательстве, новые нормативные акты ограничивали возможности банков к расширению, предпринимательской деятельности, уменьшали процент и увеличивали сроки выплат. Продажи в кредит росли вместе с повышением степени защиты потребителя [Marron 2009: 68-72].

Послевоенное время ознаменовалось кейнсианской политикой стимулирования спроса, а также переселением людей в пригороды. Всё это вызвало новую волну потребления. Стремясь получить наибольшую выгоду, универмаги строили филиалы в пригородах, рассчитывая занять доминирующие позиции на этих локальных рынках; для увеличения продаж использовалось брендирование и мгновенные кредиты (они существовали в форме счётов в магазине: хотя кредитные карты начали появляться, массовое распространение они получили лишь в конце 1960-х гг.). В начале 1960-х гг. счета, которые раньше были закрытыми (чтобы совершать новые покупки, нужно выплатить кредит), стали открытыми, или «условными» (нет предельной суммы долга, процент зависит от невыплаченной суммы) [Hyman 2011: 148-156]. Важно отметить существование расовой дискриминации в области кредита: афроамериканцы с низкими доходами не могли получить кредит, а процент для них назначался выше, чем для белых.

Параллельно развивались практики «бюджетирования», семьи начинали вести строгий бюджет, рассчитывая, какая часть дохода уходит на оплату каких кредитов и что остаётся. Зачастую месячная оборотная касса получалась совсем небольшой: так, от 574 дол. после выплат по всем кредитам могло остаться около 150 дол. на еду, хозяйство и прочие расходы [Calder 2002: 30].

\section{2. Особенности фрорм кредитования в странах Европы}

Система покупок в рассрочку оказалась самой успешной с точки зрения распространения по миру. Покупки в рассрочку стали основной формой кредитования, заимствованной Европой из Америки, 
и компания «Зингер» сыграла в этом не последнюю роль, расширив свой рынок сбыта на множество стран мира. В 1930-х гг. в Великобритании покупки в рассрочку составили половину продаж в кредит [O’Connel 2012: 87]. Принцип финансовых компаний, обеспечивающих как дилеров, так и покупателей, был заимствован из Америки и использован на рынках автомобилей и других товаров длительного пользования [Gelpi, Julien-Labruyère 2000: 130]. Особенно увеличились продажи после рассылок по почте, причём в Великобритании эта стратегия сработала даже успешнее, чем в США, где каталоги, предлагаемые фирмами национального масштаба, конкурировали с локальными кредиторами.

Везде, где закрепились покупки в рассрочку, они оказали влияние на повышение уровня жизни рабочего класса и стирание границы между ним и средним классом.

В первой половине XX века влияние Америки на европейские институты кредита ограничивалось распространением покупок в рассрочку. Для Европы этого времени была характерна специфическая система кредитования; во Франции она получила название подписной системы, или системы Дюфаэля, в Германии - кёнигсбергской системы, в Великобритании - провидентской. Формальный принцип был во всех трёх случаях одним и тем же: компания продаёт покупателям в кредит чеки или купоны, которые они затем могут обменять в магазинах на товары. Таким образом, магазины, участвующие в соглашении, могли увеличить выручку, но не несли при этом риск невыплаты и не становились объектами морального осуждения.

Систему кредитования, которая получила распространение в Великобритании, называют провидентской по имени компании Provident Clothing and Supply Company. Компания была основана в 1880 г.; к 1910-м гг. с ней сотрудничали самые разнообразные магазины, и на провидентские чеки можно было купить почти всё - «от фотографий до люлек и от барометров до искусственных зубов» [O'Connel 2012: 90]. За чеки люди платили 23,3\% годовых в течение примерно 20-24 недель. Распространение системы было во многом обусловлено отсутствием у рабочего класса альтернативных источников кредитования, требовавших устойчивого финансового положения заёмщиков. Использование чеков не только позволяло рабочим покупать в кредит, но и снимало проблему собственности, связанную с тем, что по законам того времени вещь, приобретённая в кредит, принадлежала продавцу вплоть до окончания выплат и в случае задержек он имел право её изъять. Многие владельцы магазинов противились необеспеченному увеличению спроса, однако всё равно были вынуждены сотрудничать с Provident. Финансовая и моральная несостоятельность покупателей, использовавших чеки, побуждала многих продавцов вводить дополнительные правила: например, покупателям за чеки предписывалось приходить в магазины по будням, чтобы не вредить престижу магазина; часто с них требовалась доплата сверх чека, хотя первоначальные соглашения этого не предусматривали.

Существенной чертой Provident было использование уже существующих в сообществах локальных сетей. Компания нанимала армию сотрудников - выходцев из рабочего класса на неполный день и ставила перед ними цель найти подходящих клиентов, продать им чеки и в дальнейшем следить за выплатами. Поскольку работники и покупатели принадлежали к одному слою и часто были знакомы друг с другом, вероятность невыплаты кредита снижалась радикально. Люди в гораздо меньшей степени стремились уклониться от уплаты процентов, так как дорожили своим статусом и уважением в сообществе. Таким образом, с логикой выплаты кредита смешивалась логика реципрокного дарообмена.

Разумеется, чеки не использовались как полная альтернатива деньгам. К ним прибегали в период локальных кризисов в семье, при необходимости купить одежду, а также перед Рождеством. Кроме того, наиболее благополучные покупатели использовали «цепочечные чеки» (relay checks): несколько чеков гарантировали один другой, и человек мог позволить себе крупную покупку. В 1950-е гг. развился обширный вторичный рынок чеков, их скупали и перепродавали по более высоким ценам [O'Connel 2009: 55-87; 2012: 90-95]. 
В 1960-х гг., когда популярность завоевали почтовые отправления, провидентская система смогла успешно к ней адаптироваться, и теперь около 900 тыс. работников должны были звонить своим друзьям и знакомым и представлять им каталоги, предлагающие купить товары в кредит. В 1962 г. Provident из частной компании стала публичной, и в её политике произошли новые изменения: начали выпускать ваучеры на большую сумму, чем чеки (100-200 фунтов), и под меньший годовой процент, что помогало обходить закон, не контролировавший покупки в рассрочку. В 1971 г. был основан Народный банк, предоставлявший потребительские кредиты [O’Connel 2012: 97-98].

Во Франции наибольшие распространение и успех получила подписная система компании Жоржа Дюфаэля ${ }^{6}$. Она так же основывалась на продаже в кредит купонов, которые затем можно было обменять на товары в определённых магазинах. Для продажи купонов компания, как и Provident, нанимала работников, каждый из которых отвечал за две парижские улицы. Однако важным отличием этой системы от провидентской и кёнигсбергской стала ориентация не на рабочий класс, а на более обеспеченные слои населения; рабочие во Франции продолжали использовать малые займы. К началу ХХ века у Les Grands Magasins Dufayel было уже около 3,5 млн клиентов. Как и в Америке, свою роль сыграл фактор социальной интеграции: большую долю клиентов составляли люди, переселившиеся в Париж из провинции и нуждающиеся в обустройстве жилья [Gelpi, Julien-Labruyère 2000: 136]. Однако после смерти Дюфаэля в 1916 г. универмаг стал приходить в упадок и закрылся в 1930 г.

В Германии аналогом подписной и провидентской стала кёнигсбергская система. Впервые она была представлена банком Kundenkredit GmbH, основанным в 1926 г. Кёнигсбергская система была распространена в небольших городах, а её клиентами были главным образом представители рабочего класса [Logemann 2011: 536].

Все упомянутые компании были ориентированы на покупателей, проявляли к ним дружелюбие и сочувствие. Это выражалось в том, что выплаты могли быть отложены без особых последствий, если человек, например, потерял работу.

С 1920-х гг. в Европе начали распространяться финансовые компании, обеспечивающие в первую очередь покупку автомобилей. Компании SOVAC (Citroën, 1919 г.), DIAC (Renault, 1924 г.) и DIN (Peugeot, 1928 г.) были основаны во Франции [Gelpi, Julien-Labruyère 2000: 137-138]. В Германии открылись филиалы General Motors (GM) и Ford Motor Company (Ford), и распространение американских автомобилей вызвало очередную волну критики кредита. Финансовые компании были представлены двумя типами: одни давали кредиты непосредственно покупателям, выступая посредниками между ними и продавцами («берлинская система»), другие кредитовали продавцов, которые, в свою очередь, самостоятельно предоставляли покупателям кредиты и собирали выплаты (list business, «списочный бизнес»). Впоследствии финансовые компании перестали ограничиваться рынком автомобилей и стали кредитовать агентов на рынках товаров длительного пользования [Logemann 2011: 536].

Демографический бум, полная занятость и рост благосостояния в первые два десятилетия после Второй мировой войны привели к увеличению спроса на товары, и тогда покупки в рассрочку достигли второго расцвета. Тогда же коммерческие банки начали предоставлять потребительские кредиты [Gelpi, Julien-Labruyère 2000: 138]. Кроме того, стало активно развиваться законодательство по кредитам, которое приводит к сильно регулируемому рынку во Франции и после нескольких экспериментов -

6 Ж. Дюфаэль стал новым владельцем парижского универмага, ранее принадлежавшего Жаку Франсуа Креспену, который ещё в 1860-х гг. ввёл подписную систему для продажи в кредит предметов мебели. Однако именно с деятельностью Ж. Дюфаэля, переименовавшего универмаг в Les Grands Magasins Dufayel, связаны как резкий рост популярности магазина, так и широкое распространение подписной системы, в том числе с помощью сотрудников, ходивших по домам и рекламировавших покупку в рассрочку. 
весьма свободному в Великобритании. Как в ФРГ, так и в ГДР экономическая политика относилась к кредиту скептически. Если в ГДР до 1956 г. институты кредита были ликвидированы по идеологическим основаниям (впоследствии были созданы кредитные кооперативы), то политика ФРГ с большей охотой поощряла сбережения, в связи с чем рынок кредитов в Западной Германии рос медленнее, чем, например, в США и Великобритании.

\section{4. Противостояние развитию потребительского кредита}

Критика потребительского кредита принимала в разных странах похожие формы. И в Америке, и в странах Европы апеллировали главным образом к тому, что кредит и долг противоречат определённым этическим принципам. Кроме того, в европейских странах кредит часто рассматривался как часть американской экспансии, а его осуждение связывалось с отстаиванием независимости национальной экономики. После Второй мировой войны к этим направлениям критики добавилось выявление дегуманизирующих эффектов общества потребления и капитализма в целом.

Основными средствами борьбы были публикации в газетах и журналах, призванные разоблачить аморальную природу кредита, книги, наставляющие в финансовых или более общих вопросах, лоббирование или блокирование законов, а иногда даже акции протеста [O'Connel 2012: 91]. Среди групп, которые были настроены против изменения сложившихся форм кредитования, следует назвать кредиторов, предоставляющих малые займы (особенно акулы-ростовщики), владельцев магазинов и продавцов, а также консервативно или, наоборот, критически настроенных интеллектуалов.

\section{1. Викторианская этика}

Критика кредита и долга с позиции этики, которую Л. Колдер называет викторианской, приобретает большую популярность как в Америке, так и в Европе. Поскольку критика кредита с позиций этики является логичным продолжением критики ростовщичества, её распространение на малые займы и покупки в рассрочку совпадает по времени с возникновением этих институтов, то есть она появляется примерно в середине XIX века. Основная идея состоит в том, что желание жить не по средствам происходит из необдуманности решений и неспособности к самоконтролю, то есть в целом от человеческой слабости [Logemann 2011: 538].

Более обстоятельно, чем в публицистических статьях, эти доводы представлены в сочинениях Б. Франклина и К. Мэзера 7 . Исходный постулат: благо есть то, что возвышает характер. Под характером понимается совокупность добродетелей, определяющих то, как конструируется и представляется идентичность. Поскольку характер проявляется через успехи и неудачи в достижении экономических целей, добродетели должны обеспечивать человеку доверие (без которого невозможны ни заключение сделок, ни кредит) и грамотное распоряжение деньгами. Правильное распоряжение деньгами - это их вложение. Викторианская этика заимствует из классической экономической теории различение потребления на производственное и непроизводственное. Соответственно кредит, который берётся для вложения в производство или на покупку того, что растёт в цене (недвижимость и некоторые товары длительного

7 Можно увидеть анахронизм в том, что принципы викторианской этики возводятся к работам мыслителей, живших в XVII-XVIII веках. С одной стороны, это затруднение разрешается тем, что если речь идёт именно об этике в отношении кредита, то она не могла появиться раньше самого кредита, следовательно, по периоду наибольшего влияния (вторая половина XIX века) её можно назвать викторианской, хотя базовые принципы имеют более глубокие корни. С другой стороны, можно предположить, что для Л. Колдера метафорическое значение слова «викторианский» важнее генеалогического: употреблением этого термина он стремится подчеркнуть строгость, центральную позицию нравственности и морали, страх перед осуждением со стороны общества, характерные для той эпохи. К этому примыкает то соображение, что изложение рассматриваемых этических принципов можно найти в еще более ранних источниках, в том числе у мыслителей Возрождения (например, у Л. Б. Альберти). 
пользования), одобряем, морален и расценивается как движущая сила экономики, а долг, который берётся для личного потребления, осуждается и считается аморальным.

На протяжении XIX века и в начале XX века долг критикуется писателями и проповедниками, придерживающимися идеалов викторианской этики, с позиций как рациональности (выплаты увеличивают цену товара), так и морали (долг подталкивает к мошенничеству и сам по себе происходит из желания повысить свой статус в сообществе). Кроме того, одалживание денег говорит о неумении ими распоряжаться и неспособности контролировать свои желания, результатом чего становится внешний контроль над поведением человека со стороны кредитора [Calder 1999: 87-101].

Такая этика была выгодна как обладающим властью, так и подвластным. Первые получили возможность контролировать и стимулировать рабочую силу, вторые - надежду на экономическое благосостояние, а также лучшее объяснение природы денег и кредита [Calder 1999: 86].

Однако в начале XX века викторианская этика постепенно начала уступать место представлениям о кредите как о социальном благе. Этому способствовали противоречия в традиционном взгляде на кредит и изменения в самой жизни. Во-первых, в рамках викторианской этики существовала проблема различения производственного и непроизводственного кредита, особенно обострившаяся в связи с распространением товаров быстрого пользования. Во-вторых, сдерживание удовлетворения желаний, на котором настаивала традиционная этика, закономерно приводило к постоянному внутреннему стремлению осуществить их. К этим проблемам добавилась инфляция 1897-1914 гг., которая дезориентировала тех, кто считал, что единственно верный путь к богатству - сбережения. В то же время кампания по легализации малых займов, ориентирующаяся на публичность, многое сделала для формирования нового представления о кредите [Calder 1999: 107-108].

Новая модель обоснования кредита и долга создавалась с опорой на представления викторианской этики, но ассоциации с несчастьями и недомыслием были заменены на более приятные и одобряемые. Кредиторы активно апеллировали к идеям братства, пытались показать, что все, от капиталиста до рабочего, одинаково нуждаются в кредите. Одним из важных приёмов, используемых кредиторами в своей риторике, были «истории успеха», общая схема которых была примерно такой: человек живёт в тяжёлых индустриальных условиях, его судьба складывается тяжело и несчастливо, но он избавляется от проблем с помощью кредита и достигает успеха, при этом впоследствии часто становится предпринимателем. Свою роль кредиторы видели также в повышении финансовой грамотности потребителей и, создавая свой новый образ, были готовы не только давать деньги, но и консультировать и просвещать людей. Таким образом, кредиторы начали позиционировать себя как важный элемент производства, позволяющий работникам стать производителями [Calder 1999: 137-147].

Весь этот комплекс причин привёл к тому, что к 1930-м гг. в США кредит практически перестал осуждаться и, наоборот, сочетался с образами среднего класса и американской мечты. В Европе этот процесс шёл с некоторым отставанием, и добиться общественного признания кредита удалось лишь после Второй мировой войны.

\section{2. Критика капитализма}

Со второй половины 1940-х гг., когда коммерческие банки и финансовые компании начинают задавать новые стандарты потребления и формировать образ среднего класса, ряд интеллектуалов выступили с критикой, направленной на этот раз не против людей, берущих в долг, а против самой системы потребительского кредитования. Во Франции это направление ярче всего выразил Ж. Бодрийяр. Он описал кредит как налог на бедность, делающий должников безвластными из-за страха потерять работу и 
стать некредитоспособными [Gelpi, Julien-Labruyère 2000: 139]. В Америке были весьма популярны идеи, связывавшие рост покупок в кредит и обеспечение определённого уровня потребления с конформизмом, «ложными» потребностями, отчуждением и потерей индивидуальной свободы. В этом духе высказывались среди прочих Э. Фромм и Г. Маркузе (см. подробнее: [Marron 2009: 74]).

\section{3. Критика американизма}

В Европе на критику кредита как такового накладывались ассоциации этого института с США. Потребительское кредитование рассматривалось как заимствованная форма, внутренне чуждая французской, английской или немецкой жизни. С одной стороны, критике подвергались расширение конкретных американских компаний (например, Ford или GM), открытие ими филиалов в странах Европы, подавляющее национальные экономики. С другой стороны, потребительский кредит в целом виделся частью американской культуры, американского образа жизни. Конкурентная борьба фирм, массовое потребление и американская мечта среднего класса воспринимались значительной долей населения не как желательное состояние общества, а как навязываемые извне идеалы [Gelpi, Julien-Labruyère 2000: 139; Logemann 2011: 537; O’Connel 2012: 91].

\section{5. Заключение}

Культурная и социальная история потребительского кредитования не может предложить простых схем для понимания роли кредита в жизни людей и сообществ. Однако, с успехом избегая односторонних оценок, она в то же время не сводится к реконструкциям статистических показателей и спискам социальных групп и товаров, связанных с ростом кредита. История кредита предлагает перспективу, связывающую, с одной стороны, кредитные и долговые отношения с социальными общностями и культурным контекстом, а с другой - современные формы кредитования с предшествующими им институтами. При таком рассмотрении само словосочетание «современные формы кредитования» кажется уместным только в аналитическом смысле. Во всяком случае, рассмотренное разнообразие форм потребительского кредита, сменяющих друг друга и по-разному совмещаемых с существующими практиками сообществ, разрушает преобладавшие в течение всего XX века мифы о некоем едином кредите, ворвавшемся в традиционные сообщества и то ли улучшившем их жизнь, то ли разрушившем её. В контексте культурной и социальной истории кредита становится очевидно, что отношения людей с кредитами были и остаются значительно более сложными.

История кредита, как уже отмечалось, достаточно новое направление, и вопросов она пока ставит больше, чем даёт ответов. Почему в некоторых случаях институтам кредита удаётся опереться на локальные сообщества, а в других - нет? Когда и при каких условиях люди начинают предпочитать кредит (в какой бы то ни было форме) личному займу? Чем обусловлены различия между формами кредитования, возникшими в разных странах? В каких отношениях потребительский кредит находится с социальной интеграцией: ослабляет её, усиливает, изменяет содержательно или это происходит по-разному в зависимости от каких-то других факторов? Почему критика чаще всего оказывается бессильной остановить распространение кредита? Все эти вопросы, оправданные именно в связи с развитием истории кредита, важны не только сами по себе, но и потому, что они позволяют установить связь между историческими исследованиями и экономической социологией, которая может как обогатить свою предметную область новыми данными, расширяющими её перспективу, так и предложить истории кредита теоретически обоснованную аргументацию, позволяющую прослеживать причинноследственные связи, и мощный понятийный аппарат анализа. 


\section{Приложение}

\section{Наиболее распространённые формы кредитования по странам и историческим периодам}

\begin{tabular}{|c|c|c|c|c|c|}
\hline США & $\begin{array}{c}\text { Малые займы } \\
\text { (нелегальный } \\
\text { рынок) }\end{array}$ & $\begin{array}{c}\text { Малые займы } \\
\text { (легальный ры- } \\
\text { нок), почтовые } \\
\text { рассылки, фи- } \\
\text { нансовые компа- } \\
\text { нии }\end{array}$ & $\begin{array}{c}\text { Рассрочка, малые } \\
\text { займы }\end{array}$ & $\begin{array}{c}\text { Коммерческие } \\
\text { банки, рас- } \\
\text { срочка }\end{array}$ & $\begin{array}{c}\text { Коммерческие } \\
\text { банки, рас- } \\
\text { срочка, мгно- } \\
\text { венные креди- } \\
\text { ты }\end{array}$ \\
\hline $\begin{array}{l}\text { Велико- } \\
\text { британия }\end{array}$ & $\begin{array}{c}\text { Tallymen } \\
\text { (отметчики), } \\
\text { ломбарды }\end{array}$ & $\begin{array}{c}\text { Провидентская } \\
\text { система }\end{array}$ & $\begin{array}{c}\text { Провидентская си- } \\
\text { стема, финансовые } \\
\text { компании }\end{array}$ & $\begin{array}{c}\text { Провидентская } \\
\text { система, рас- } \\
\text { срочка }\end{array}$ & $\begin{array}{l}\text { Почтовые рас- } \\
\text { сылки, вауче- } \\
\text { ры, рассрочка }\end{array}$ \\
\hline Франция & $\begin{array}{c}\text { «Monts- } \\
\text { de-piétés» } \\
\text { («горы благо- } \\
\text { честия») }\end{array}$ & $\begin{array}{c}\text { Система Дюфаэ- } \\
\text { ля }\end{array}$ & $\begin{array}{c}\text { Финансовые компа- } \\
\text { нии }\end{array}$ & $\begin{array}{c}\text { Система Дю- } \\
\text { фаэля, финан- } \\
\text { совые компа- } \\
\text { нии }\end{array}$ & $\begin{array}{c}\text { Финансовые } \\
\text { компании (Cet- } \\
\text { elem) }\end{array}$ \\
\hline $\begin{array}{l}\text { Герма- } \\
\text { ния* }\end{array}$ & $\begin{array}{l}\text { «Кредитные } \\
\text { дома» }\end{array}$ & $\begin{array}{c}\text { «Кредитные } \\
\text { дома» }\end{array}$ & $\begin{array}{c}\text { Кёнигсбергская си- } \\
\text { стема, финансовые } \\
\text { компании (берлин- } \\
\text { ская система и list } \\
\text { business («списоч- } \\
\text { ный бизнес»)) }\end{array}$ & $\begin{array}{c}\text { Расширение } \\
\text { кредита (в } \\
\text { основном - } \\
\text { продажа авто- } \\
\text { мобилей) }\end{array}$ & $\begin{array}{c}\text { Коммерческие } \\
\text { банки, рас- } \\
\text { срочка }\end{array}$ \\
\hline 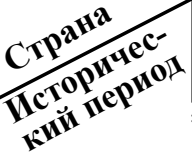 & XIX век & 1910-е гг. & 1920-е гг. & 1930-е гг. & $\begin{array}{c}\text { После Второй } \\
\text { мировой войны }\end{array}$ \\
\hline
\end{tabular}

\section{Литература}

Calder L. 1999. Financing the American Dream: A Cultural History of Consumer Credit. Princeton: Princeton University Press.

Calder L. 2002. The Evolution of Consumer Credit in the United States. In: Durkin T. A., Staten M. (eds) The Impact of Public Policy on Consumer Credit. New York: Springer Science + Business Media; 23-35.

Gelpi R.-M., Julien-Labruyère F. 2000. The History of Consumer Credit: Doctrines and Practices. New York: Palgrave Macmillan.

Hsu C. Y., Luckett T. M., Vause E. 2015. Introduction. In: Hsu C. Y., Luckett T. M., Vause E. (eds) The Cultural History of Money and Credit: A Global Perspective. Lanham: Lexington Books; ix-xxv.

Hyman L. 2011. Debtor Nation: The History of America in Red Ink. Princeton: Princeton University Press.

Jeacle I., Walsh E. J. 2002. From Moral Evaluation to Rationalization: Accounting and the Shifting Technologies of Credit. Accounting, Organizations and Society. 27: 737-761.

Logemann J. 2011. Americanization through Credit? Consumer Credit in Germany, 1860s-1960s. Business History Review. 85: 529-550. 
Logemann J. 2012. Introduction: Toward a Global History of Credit in Modern Consumer Societies. In: Logemann J. (ed.) The Development of Consumer Credit in Global Perspective: Business, Regulation, and Culture. New York: Palgrave Macmillan; 1-20.

Marron D. 2009. Consumer Credit in the United States: A Sociological Perspective from the 19th Century to the Present. New York: Palgrave Macmillan.

Meyer S. 2012. Economic Agents and the Culture of Debt. In: Logemann J. (ed.) The Development of Consumer Credit in Global Perspective: Business, Regulation, and Culture. New York: Palgrave Macmillan; 223241.

Neifeld M. R. 1941. Institutional Organization of Consumer Credit. Law and Contemporary Problems. 8: $23-35$.

O'Connell S. 2009. Credit and Community: Working-Class Debt in the UK since 1880. Oxford: Oxford University Press.

O'Connel S. 2012. The Business of Working-Class Credit: Subprime Markets in the United Kingdom since 1880. In: Logemann J. (ed.) The Development of Consumer Credit in Global Perspective: Business, Regulation, and Culture. New York: Palgrave Macmillan; 85-107. 


\title{
PROFESSIONAL REVIEWS
}

\section{Gleb Novikov}

\section{An Outline of the History of Consumer Credit}

\author{
NOVIKOV, Gleb - BA Student, \\ Faculty of Social Sciences; \\ Research Assistant, Laboratory \\ for Studies in Economic Sociology, \\ National Research University \\ Higher School of Economics. \\ Address: 20 Myasnitskaya str., \\ Moscow, 101000, Russian \\ Federation.
}

Email:nov.gleb.evg@yandex.ru

\begin{abstract}
This overview presents the characteristics and an analysis of historical forms of consumer crediting. The theoretical basis of the overview is rooted in the cultural and social history of consumer credit - a new and interdisciplinary direction. Because a distinct emphasis is placed on the differences between forms of crediting in certain countries and historical periods, the cultural and social history of credit appears to be the most appropriate for considering forms of consumer credit as they change throughout history.
\end{abstract}

It also focuses on the history of credit institutional conditions that shaped current forms of crediting. The conditions include legislation regulating debt relations more or less rigorously and forms of credit that have already existed, such as pawnshops, small loans, installment credits, family loans, and open-book credits. Furthermore, the development of consumer credit in the USA and in Europe is analyzed. In the USA, the key processes have been the legalization and legitimation of small loans, the proliferation of installment purchases, and the evolution of credit accounting, whereas in Europe, check credit systems (particularly that which was realized in the United Kingdom by the Provident Clothing and Supply Company) that have no analogues in America are of major interest. Then, the criticisms of credit are taken into account as they appeared throughout its development. The main directions of the counteractions were ethical, anti-capitalist, and anti-American criticism. In the conclusion, it is indicated that research in the history of credit is relevant to both the economists and sociologists in the field and to improving our understanding of the complexity and ambiguity of the various factors that have shaped what we now know as consumer crediting.

Keywords: consumer credit; history of credit; cultural history; social history; community; credit accounting; financial companies; check credit systems.

\section{References}

Calder L. (1999) Financing the American Dream: A Cultural History of Consumer Credit, Princeton: Princeton University Press.

Calder L. (2002) The Evolution of Consumer Credit in the United States. The Impact of Public Policy on Consumer Credit (eds. T. A. Durkin, M. Staten), New York: Springer Science + Business Media, pp. 23-35.

Gelpi R.-M., Julien-Labruyère F. (2000) The History of Consumer Credit: Doctrines and Practices, New York: Palgrave Macmillan.

Hsu C. Y., Luckett T. M., Vause E. (2015) Introduction. The Cultural History of Money and Credit: A Global Perspective (eds. C. Y. Hsu, T. M. Luckett, E. Vause), Lanham: Lexington Books, pp. ix-xxv.

Hyman L. (2011) Debtor Nation: The history of America in Red Ink, Princeton: Princeton University Press. 
Jeacle I., Walsh E. J. (2002) From Moral Evaluation to Rationalization: Accounting and the Shifting Technologies of Credit. Accounting, Organizations and Society, vol. 27, pp. 737-761.

Logemann J. (2011) Americanization through Credit? Consumer Credit in Germany, 1860s-1960s. Business History Review, vol. 85, pp. 529-550.

Logemann J. (2012) Introduction: Toward a Global History of Credit in Modern Consumer Societies. The Development of Consumer Credit in Global Perspective: Business, Regulation, and Culture (ed. J. Logemann), New York: Palgrave Macmillan, pp. 1-20.

Marron D. (2009) Consumer Credit in the United States: A Sociological Perspective from the 19th Century to the Present, New York: Palgrave Macmillan.

Meyer S. (2012) Economic Agents and the Culture of Debt. The Development of Consumer Credit in Global Perspective: Business, Regulation, and Culture (ed. J. Logemann), New York: Palgrave Macmillan, pp. 223-241.

Neifeld M. R. (1941) Institutional Organization of Consumer Credit. Law and Contemporary Problems, vol. 8, pp. 23-35.

O'Connell S. (2009) Credit and Community: Working-Class Debt in the UK since 1880, Oxford: Oxford University Press.

O'Connel S. (2012) The Business of Working-Class Credit: Subprime Markets in the United Kingdom since 1880. The Development of Consumer Credit in Global Perspective: Business, Regulation, and Culture (ed. J. Logemann), New York: Palgrave Macmillan, pp. 85-107.

Citation: Novikov G. (2017) Ocherk istorii potrebitel'skogo kredita [An Outline of the History of Consumer Credit]. Journal of Economic Sociology = Ekonomicheskaya sotsiologiya, vol. 18, no 1, pp. 80-95. Available at: https://ecsoc.hse.ru/2017-18-1.html (in Russian). 


\section{НОВЫЕ КНИГИ}

\section{Н. В. Конрой \\ Странные экономики, в которых мы живём}

Рецензия на книгу: Gudeman S. 2016. Anthropology and Economy. Cambridge: Cambridge University Press. 225 p.

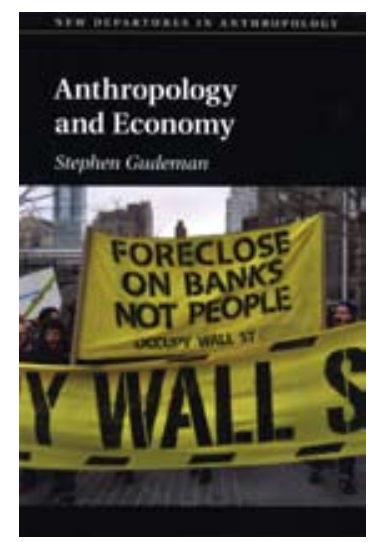

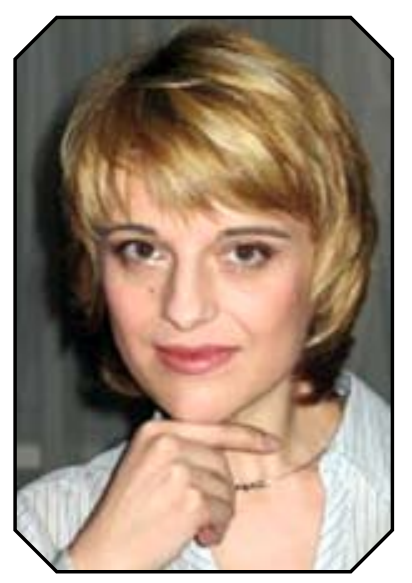

КОНРОЙ Наталья Викторовна кандидат исторических наук, научный сотрудник Лаборатории экономикосоциологических исследований (ЛЭСИ) Национального исследовательского университета «Высшая школа экономики». Адрес: 101000, Россия, г. Москва, ул. Мясницкая, д. 20.

Email: nconroy@hse.ru
Новая книга эконом-антрополога Стивена Гудемэна посвящена анализу баланса корысти (self-interest) и взаимности (mutuality) в экономических отношенияхиосновываетсянашироком этнографическомматериале, собранном автором и его коллегами в разные годы ХХ века. В качестве теоретической схемы Гудемэн предлагает модель пяти институциональных сфер - домохозяйства (house), сообщества (community), торговли (соттеrсе), финансов (finance) и глобальных финансов (meta-finance). В данной модели сочетание торговли, финансов и глобальных финансов характеризует состояние современного капитализма. С одной сторонь, сферы представляют собой историческую последовательность, отражающую изменения в скорости, количестве, уровне абстракиии экономических трансакций. С другой стороны, экономические сферы взаимозависимы и существуют одновременно, в тесном взаимодействии и конфликте. Взаимодействие обеспечивается с помощьью различных связывающих механизмов (рента, бартер, деньги и др.), а конфликт проявляется в моменты столкновения двух сторон экономической жизни - эмпатии и конкуренции. Особенность современного рыночного капитализма, по мнению Гудемэна, заключается в безудержном росте ренты, которая даёт банкам, производителям, продавиам товаров и услуг неконкурентные преимущества, но прикрывается риторикой конкуренции и вытесняет на периферию сочувствие как часть экономического взаимодействия. Дисбаланс порождает неравенство, от которого страдают наименее защчщённые участники экономических отношений - домохозяйства и сообщества. Как полевой антрополог, Гудемэн демонстрирует приверженность дисииплинарной традиции, выступая защитником и представителем изучаемых групп, которыми, в его случае, являются не этнические, религиозные, субкультурные и проч. объединения, алюди, живущие по приземлённым правилам первых двух экономических сфер. Mеры, предлагаемые Гудемэном для восстановления баланса корысти и взаимности, вряд ли могут стать предметом обсуждения правительств. В то же время книга представляет собой важный вклад в антропологическую критику современных капиталистических отношений.

Ключевые слова: экономическая антропология; сферы экономики; корысть; взаимность; рента; бережливость; неравенство. 


\section{О чём эта книга}

Книга Стивена Гудемэна, профессора антропологии Университета Миннесоты, вышла в серии «Новые направления в антропологии», но концептуально и содержательно является продолжением ряда его прежних работ [Gudeman 1986; 2001; 2008] и коллективных проектов [Gudeman, Rivera 1990; Gudeman, Hann 2015a; 2015b] ${ }^{1}$. Суммируя этот опыт, автор утверждает, что для антрополога любые экономики, традиционные или современные, являются странными и непонятными (strange), поскольку сочетают корысть (self-interest) и взаимозависимость (mutuality). В качестве примера типичных акторов странной экономики в начале своей новой книги он приводит инвесторов финансовой пирамиды Бернарда Мейдоффа, которые, с одной стороны, стремились «делать деньги», а с другой - хотели ощущать этническую связь с основателем компании. Выбор примера неслучаен, поскольку на этот раз антрополог пытается прояснить для читателя странности современного капитализма (именно это объясняет выход книги в названной серии). Современные экономики редко оказываются в центре внимания антропологов, хотя значительная часть странностей этих экономик укоренена на любимом антропологами и почти не изученном экономистами микроуровне домохозяйства (economy rooted in the house).

В действительности, считает автор рецензируемой книги, экономика домохозяйства и конкурентная торговля (competitive trading) - это две стороны экономической жизни, которые тесно связаны: мы одновременно и конкурируем с другими, и сочувствуем им, мы измеряем одни вещи и считаем неизмеримыми другие, постоянно сталкиваясь как с общественными, так и с личными противоречиями. Другими словами, на практике каждая экономика представляет собой подвижную комбинацию конкуренции и взаимности. Гудемэн приводит пример «крупных покупок» в Америке (машина, дом, бытовая техника), выбор которых сопряжён с высокой неопределённостью и часто осуществляется с помощью посредника-менеджера, проявляющего интерес и сочувствие к личным обстоятельствам покупателя, а в отдельных случаях даже становящегося его «другом». Такая «дружба» заканчивается вместе с подписанием контракта, и Гудемэн задаётся вопросами: как и почему (с точки зрения антропологии) коммуникабельность (sociability) вплетается в рыночные отношения, позволяя нам быстро обретать и терять друзей-агентов? По Гудемэну, покрывало дружбы призвано скрывать антагонизм участников трансакции, различия их интересов; оно и поддерживает, и сопротивляется рыночному взаимодействию. Договорные отношения кажутся независимыми, но на деле невозможны без человеческого общения (sociability), и торговые агенты часто максимизируют прибыль, прикрываясь маской дружбы. Более того, практически каждая рыночная сделка сопровождается ритуальным сдвигом в противоположную сторону, словом или действием переносится в контекст обмена, а значит, и антропологам есть что сказать о современном капитализме.

\section{Как написана эта книга}

Исследовательский интерес, метод и цель исследования Гудемэна подчёркнуто традиционны (можно было бы даже сказать - утрированно старомодны, хотя автор и сам отмечает, что современные антропологи всё реже идут выбранным им путём). Он ищет сходства и различия (или, по его словам, различия сходств и сходства различий) в экономиках и проводит кросскультурные сравнения большого количества этнографических материалов, собранных в разное время в различных географических контекстах, чтобы лучше понять ситуацию, в которой сегодня живём мы, люди развитой рыночной экономики (понять других, чтобы понять себя).

1 В рецензируемой книге использованы многочисленные примеры из исследований постсоветских экономик, которые были выполнены в 2009-2012 гг. в рамках возглавляемого С. Гудемэном и К. Ханном проекта, реализованного в Институте Макса Планка. 
Он обращается как к собственным полевым материалам, собранным им в Панаме в конце 1960-х гг. и (вместе с Альберто Ривьерой) в Колумбии в конце 1970-х гг., так и к данным других антропологов разных поколений (например, он использует материалы Орди Ричардс по бемба Южной Африки и Рео Форчуна по добу Новой Гвинеи, записанные в 1930-х гг.; описание близкой к бемба группы биса, сделанное в 1940-х гг. Стюартом Марксом, и в эти же годы проведённое Дереком Фримэном исследование ибан острова Борнео; результаты работы Эндрю Стратерна в Маунт-Хаген на Новой Гвинее в 1960-х гг. и многое другое). К осмыслению полевых материалов Гудемэн привлекает не только антропологическую теорию (Дж. Дж. Фрэзер, М. Мосс, Л. Дюмон, Э. Дюркгейм, Б. Малиновский, К. ЛевиСтрос, М. Салинс и др.), но и модели классической экономики и политэкономии (Д. Стюарт, А. Смит, Д. Рикардо, К. Маркс, В. Парето).

Чтобы облегчить читателю восприятие теории и скрасить одиночество путешествия по странам и культурам, автор не просто ведёт рассказ от первого лица, но вводит в повествование две анонимные фигуры - интерпретирующего антрополога и экономиста, который заглядывает через плечо антрополога (over-the-shoulder economist) и предлагает собственные объяснения увиденного.

В такой необычной компании спорящих антропологов и экономиста читателю предстоит одолеть восемь глав книги и узнать, что, несмотря на то что сегодня в повседневном и научном дискурсах понятие «экономика» порой неоправданно сужается до понятия «рынок», идею о том, что в экономической жизни высшие классы сочувствуют низшим, смягчая безжалостность рыночной конкуренции, высказал ещё Адам Смит (поэтому найти общий язык и основания антропологам и экономистам проще, чем кажется). Возможно, читатель даже согласится с антропологами, что обе стороны экономической жизни - домашняя и рыночная - существуют благодаря верованиям и ритуалам. В домашней сфере с помощью ритуала закрываются бреши в близких связях родства и свойства; в рыночной ритуалами, церемониями и магическими заклинаниями (в форме рекламы) преодолевается пропасть, разделяющая экономного домохозяина и рыночных торговцев. И хотя сегодня рынок доминирует, его стабильность финансово обеспечивается домохозяйствами, а значит, функционирование рынка напрямую зависит от эффективности ритуальной сферы.

Читатель узнает, что, с точки зрения антропологов, рыночные товары, превращающиеся в дары, связывают людей. Гудемэн приводит культуру обмена открытками в современной Америке как пример наиболее доступного и популярного средства сохранения широких связейํㅡ, но и другие товарные категории по-своему служат достижению той же цели: косметика и парфюмерия, одежда и пища - все они являются магическими инструментами привлечения и удержания других. Таким образом, развитая рыночная экономика, как и любая другая, зависима от церемоний перераспределения и дележа, от ритуального календаря (не столько потому, что этот последний временно останавливает производство, сколько в силу того, что он отмечает моменты, запускающие обмен).

Наконец, выяснится, что иногда антропологи тоже строят «модели». Так, Гудемэн, сторонник сферического подхода к экономике, выделяет (в том числе как историческую последовательность) пять сфер (секторов) экономики, уровень абстракции и охвата, а также скорость и количество трансакций в кото-

2 Заметный рост и до того развитой индустрии открыток отмечается после кризиса 2008 г. и в Великобритании, где, по данным 2015 г., потребление составило 31 открытку на человека в год. За 11 месяцев 2016 г. британцы отправили друг другу 105 млн индивидуальных открыток, потратив на них 184 млн фунтов, что на 15 млн больше, чем за тот же период 2015 г. Ожидаемый оборот рождественских индивидуальных и мелкооптовых открыток, продающихся в упаковках по 10-20 шт., оценивался Ассоциацией поздравительных открыток (Greetings Card Association) в 384 млн фунтов. Согласно исследованию Royal Mail, 60\% британцев сохраняют традиционные адресные книги с контактами родных и друзей и предпочитают получать бумажные открытки (URL: http://www.telegraph.co.uk/news/2016/12/17/christmas-cards-survivedigital-age-going-upmarket/). Кроме того, растет популярность формата больших индивидуальных открыток, упакованных в поздравительную коробку, которые не только дополняют, но иногда заменяют собой подарок. 
рых последовательно нарастают: домохозяйство (house), локальное сообщество (community), товарные рынки (commerce), финансовые рынки (finance), глобальные финансы (meta-finance).

Первая сфера (домохозяйство), по мнению Гудемэна, является наиболее сокровенным, ранним и близким к земле компонентом экономики, обеспечивающим её материальную базуз ${ }^{3}$ «Следы», отголоски и метафоры домашней экономики можно найти в более поздних сферах «большой» экономики, частью и основой которых она является. В то же время эта сфера всегда неполна и несамодостаточна, находится внутри более широких социальных связей и обменов, зависит от локальных типов семьи, родственных, детско-родительских, дружеских, кооперативных и прочих отношений.

В основе экономических связей сообщества могут лежать этничность, религия, родство или другие отношения, подкреплённые практиками дележа (sharing), то есть совместного использования пастбищ, земель, охотничьих угодий. Экономика сообщества, как в значительной степени и товарные рынки, поддерживается не формальными договорами, а общественными соглашениями о том, что остаётся общей или индивидуальной собственностью, исключаясь из рыночного обмена. Современные рынки товаров и услуг объединяют три последние сферы - товарные рынки, финансовые рынки, глобальные финансы - и являются наиболее абстрактной частью модели.

Экономические сферы растут, сжимаются, перекрываются и конфликтуют между собой. В каждой из них по-разному проявляются противоречия между эгоистичными интересами и взаимностью акторов. Каждая из них по-своему сохраняет, преумножает и распределяет богатство, используя разнообразные механизмы (от обмена до принятия риска), хотя модели и типы распределения могут комбинироваться. Так, утверждает Гудемэн, экономность, или бережливость (thrift), которая в рамках домохозяйства является превентивной практикой, способом накопления и «заглушкой» на потреблении, на уровне корпораций может становиться средством извлечения прибыли за счёт сокращения количества работников или использования побочных продуктов. Гудемэн полагает, что экономия на уровне домохозяйства «субсидирует» рынок, поскольку расширение домашнего производства в условиях ограниченных ресурсов выводит часть произведённого продукта на продажу. Свой вклад в поддержание рынка вносит и сообщество, распространяя по социальным сетям информацию о качестве товаров и услуг и снижая издержки бизнеса на рекламу.

Продвигаясь от главы к главе, Гудемэн показывает, как различные экономические феномены - свободный дар ${ }^{4}$, рента, бартер, деньги - вписываются в его схему пяти институциональных сфер, какие вариации этих явлений возникают в каждой и какие из них являются наиболее эффективными механизмами связывания различных сфер экономики между собой. Особое внимание исследователь уделяет формам ренты (дань, десятина, арендная плата за землю, доля (процент), дивиденды, капитальная прибыль, авторские (лицензионные) платежи, профиты и т. п.), которые защищаются с помощью формирования монополий и отношений кумовства, блата, непотизма, поддерживаются правительствами, подкрепляются идеологической и политической властью. Установление и взимание ренты ведёт к неравенству, и в трёх абстрактных сферах, составляющих современную рыночную экономику, идёт стремительное распространение и рост разнообразия ренты, получаемой бизнесом и банками кроме прибыли, заработанной в честной конкурентной борьбе. Гудемэн приводит примеры разнообразных выплат, полагающихся высшему топ-менеджменту, но редко связанных с реальной продуктивностью последнего.

3 Некоторые антропологи разделяют его взгляд на «малую» экономику домохозяйства как на основу, без которой невозможно функционирование «большой» экономики; другие видят в «малой» экономике сферу, которая неизбежно сокращается, вытесняется в угоду корысти и максимизации прибыли.

4 Возможность существования или, как минимум, включения свободного дара в сферу экономики многими антропологами ставится под сомнение. Гудемэн решает проблему, переопределив свободный дар как одну из разновидностей ренты. 


\section{Какое впечатление оставляет эта книга}

В целом книга представляет собой интересную попытку применить сложившийся понятийный аппарат экономической антропологии и авторскую схему экономических сфер к объяснению как экономической повседневности (например, распространение бартерных клубов в Миннесоте), так и циклических проблем, затрагивающих простых американцев, и здесь антрополог оказывается верен дисциплинарной привязанности к уровню домохозяйства ${ }^{5}$. Гудемэн анализирует потрясения 1980-2000-х гг. (кризис кредитов и вкладов 1980-х гг., крах хедж-фонда Long-Term Capital Management, пузырь дот-комов (dot-com stock bubble) и, наконец, недавние банковский и ипотечный кризисы). Так, например, он объясняет затянувшееся после ипотечного кризиса восстановление домохозяйств разной степенью вмешательства государства в преодоление последствий кризисов 2008 г.: государство больше инвестировало в спасение банков (underwater banks), чем граждан (underwater homes). Несправедливое в отношении домохозяйств распределение господдержки в периоды кризиса, согласно Гудемэну, обусловлено тем, что домохозяйства не полностью находятся в сфере рыночной экономики, то есть являются для государства слишком приземлёнными, конкретными и далёкими от высокоабстрактной сферы современного капитализма.

Ещё одна дисциплинарная особенность этой книги, как мне кажется, проявляется в верности автора мысли о том, что антрополог должен выступать адвокатом исследуемых групп и пытаться улучшить их положение. В случае «Антропологии и экономики» такой группой оказываются все люди, чья повседневная жизнь проходит на уровнях домохозяйства и сообщества. Неслучайно для обложки книги была выбрана фотография демонстрантов движения «Occupy Wall Street», несущих плакат «Взыскивайте с банков, а не с людей» («Foreclose on banks not people»). Гудемэн размышляет о том, как можно преодолеть разрыв между абстрактной и безжалостной сферами высокого рынка и миром обычных граждан, страдающих от экономического неравенства, циклических кризисов, деградирующей экологии, от растущих явных и скрытых поборов-рент, взимаемых банками, производителями, продавцами товаров и услуг за разнообразные экономические «риски». Не все его предложения кажутся реализуемыми. Несколько утопичными выглядят попытки найти соответствия домашней экономики традиционных обществ в современных реалиях. Благим, но необоснованным пожеланием представляется идея введения добавленного налога на энергию (energy added tax), хотя о назревшей необходимости поиска баланса между корыстью и взаимностью с нарастающей тревогой говорят не только антропологи, что делает «Антропологию и экономику» своевременной и интересной.

Несмотря на увлекательность, сложно назвать эту книгу лёгким чтением. Даже читателю, в студенческие годы успешно прошедшему испытание антропологической классикой, потребуется некоторое усилие, чтобы, удержав в памяти многочисленные примеры, выстроить связи между ними и некоей большой идеей (схемой, моделью), которую предлагает автор. «Антропология и экономика» в хорошем смысле возвращает нас к жанру, в котором был столь силён Дж. Дж. Фрэзер, хотя Гудемэн подчёркивает, что не является приверженцем эволюционистской традиции. Наверное, иногда такие книги должны появляться и пробуждать в нас теоретические амбиции. Книгу стоит читать, чтобы расширить кругозор и окунуться в многообразие экономических практик; понять, как эконом-антропологи определяют свою позицию по отношению к современному капитализму и предлагают его усовершенствовать; и, может быть, даже для того, чтобы попытаться пересобрать кусочки мозаики профессора Гудемэна и поспорить с ним.

5 Конечно, его прочно удерживает на этом уровне выбранная им стратегия написания текста: привлекая обширный сравнительный материал коллег, работавших в традиционных обществах, он вынужден вновь и вновь обращаться к истокам. 


\section{Литература}

Gudeman S. 1986. Economics as Culture. Models and Metaphors of Livelihood. London; Boston; Henley: Routledge \& Kegan Paul.

Gudeman S. 2001. The Anthropology of Economy: Community, Market and Culture. Malden: Blackwell Publishers.

Gudeman S. 2008. Economy’s Tension. New York: Berghahn Books.

Gudeman S., Rivera A. 1990. Conversations in Colombia: The Domestic Economy in Life and Text. Cambridge: Cambridge University Press.

Gudeman S., Hann C. (eds) 2015a. Economy and Ritual .Studies of Postsocialist Transformations. New York: Berghahn Books.

Gudeman S., Hann C. (eds) 2015b. Oikos and Market: Explorations in Self-Sufficiency after Socialism. New York: Berghahn Books. 


\section{NEW BOOKS}

\section{Natalia Conroy \\ Strange Economies We Live in}

Book Review: Gudeman S. (2016) Anthropology and Economy, Cambridge: Cambridge University Press. $225 \mathrm{p}$.

\section{CONROY, Natalia - Candidate \\ of Sciences in History, \\ Researcher, Laboratory for Studies in Economic sociology \\ (LSES), National Research \\ University Higher School \\ of Economics. Address: 20 \\ Myasnitskaya str., Moscow, 101000, Russian Federation.}

\section{Email: nconroy@hse.ru}

\section{Abstract}

A new book by the economic anthropologist Stephen Gudeman presents the analysis of the balance between self-interest and mutuality in economic relations. It is based on the extensive ethnographic data collected by the author and his colleagues during $20^{\text {th }}$ century. As a theoretical schema Gudeman offers a model of the five institutional spheres: house, community, commerce, finance and meta-finance, in which the combination of the last three characterizes the state of modern capitalism. These spheres, on the one hand, represent a historical sequence that reflects changes in the speed, quantity and level of abstraction in economic transactions. On the other hand, the economic spheres are interdependent and exist simultaneously in close cooperation and conflict. Collaboration works through various linking mechanisms such as rent, barter, money, etc., and conflicts manifest themselves when two sides of the economic life - empathy and competition - confront each other. According to Gudeman, the feature of modern market capitalism is the unrestrained growth of rents. Rents give the banks, manufacturers, sellers of goods and services non-competitive benefits, which are covered by the rhetoric of competition and displace empathy as an important part of economic life. This imbalance creates inequality for household and community as the least protected participants in economic relations. A field anthropologist, Gudeman demonstrates the commitment to disciplinary traditions to advocate and represent the groups under study. For him, these groups are not ethnic, religious or subcultural, but all people living in the mundane rules of the first two economic spheres. Although the measures that Gudeman proposes to restore the balance of self-interest and mutuality can hardly be discussed and certainly won't be implemented by governments, the book represents an important contribution to the anthropological critique of modern capitalism.

Keywords: economic anthropology; spheres of economy; self-interest; mutuality; rent; thrift; inequality.

\section{References}

Gudeman S. (1986) Economics as Culture. Models and Metaphors of Livelihood, London; Boston; Henley: Routledge \& Kegan Paul.

Gudeman S. (2001) The Anthropology of Economy: Community, Market and Culture, Malden: Blackwell Publishers.

Gudeman S. (2008) Economy’s Tension, New York: Berghahn Books.

Gudeman S., Rivera A. (1990) Conversations in Colombia: The Domestic Economy in Life and Text, Cambridge: Cambridge University Press. 
Gudeman S., Hann C. (eds) (2015a) Economy and Ritual Studies of Postsocialist Transformation, . New York: Berghahn Books.

Gudeman S., Hann C. (eds) (2015b) Oikos and Market: Explorations in Self-Sufficiency after Socialism, New York: Berghahn Books.

Citation: Conroy N. (2017) Strannye ekonomiki, v kotorykh my zhivem [Strange Economies We Live in]. Book Review on Gudeman S. (2016) Anthropology and Economy. Cambridge: Cambridge University Press. Journal of Economic Sociology = Ekonomicheskaya sotsiologiya, vol. 18, no 1, pp. 96-103. Available at: https://ecsoc.hse.ru/2017-18-1.html (in Russian). 


\section{КОНФЕРЕНЦИИ}

\section{Е. К. Соколова}

\section{Свидетели антропологии}

\section{5-я Ежегодная конференция Американской антропологической ассоциации, г. Миннеаполис, 16-20 ноября 2016 г.}

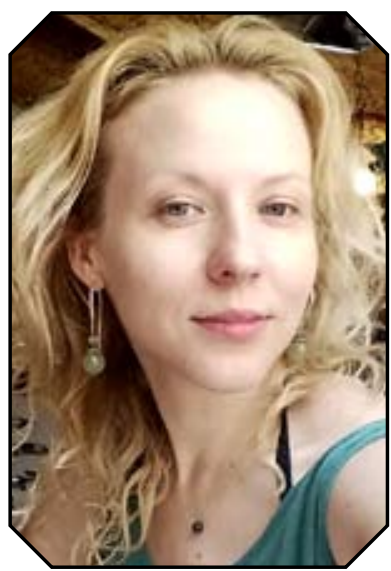

СОКОЛОВА Елена Константиновна аспирант Института этнологии и антропологии имени Н. Н. Миклухо-Маклая РАН. Адрес: Россия, 119991, г. Москва, Ленинский проспект, 32a.

\section{Email:}

elena.k.sokolova@ gmail.com
Ежегодная конференция Американской антропологической ассоичащчии 1 одно из наиболее масштабных международных мероприятий, посвящённых антропологии. Согласно информации, приведённой на сайте ассоциации, речь идёт о 750 сессиях и о более чем 6000 исследователях со всего мира. В работе конференции принимают участие крупнейшие сообщества, такие, например, как Общество культурной антропологии, а также более специализированные секции, группь и комитеты.

В настоящем обзоре рассматриваются и анализируются тематика ежегодной конференции, особенности её программы, масштабность и ориентация на карьеру антрополога, восприятие профессиональным сообщчеством позиции антрополога как исследователя, а также различные аспекты эволюции этнографического метода. Во время работы конференuии, тема которой формулировалась как "Evidence. Accident. Discovery» («Свидетельство. Случай. Открытие»), автор сделала ряд наблюдений, которыми делится с читателем, при этом внимание будет уделено образовательным программам внутри сообщества и важности неформальной коммуникации в рамках конференции. Особый акцент делается на обращении современной антропологии к массовым коммуникациям, в основном к ичифровым, и работе с сочииальными сетями и блогами.

В 2017 г. конференция сосредоточится на поддержке активной социальной позиции «антропологического расследования, транслячии, влияния и действия»; её название формулируется как «Anthropology Matters!»«Антропология имеет значение!». Посещение конференции может быть полезным сразу по многим причинам: это возможность наблюдать за развитием профессионального сообщества, знакомиться с актуальными направлениями в антропологии и вопросами методологии, а также получить отклик на собственные исследовательские проектьл.

Ключевые слова: антрополог; антропология; этнография; Американская антропологическая ассоциация; конференция; образование; карьера; блог; социальные сети.

Тема Ежегодной конференции Американской антропологической ассоциации, которая проходила в Миннеаполисе, в 2016 году была заявлена как: «Evidence. Accident. Discovery», что можно перевести как «Свидетельство.

$1 \quad$ URL: https://eventscribe.net/2016/aaa/index.asp 
Случай. Открытие», но не исключены и другие варианты перевода. Большинство пленарных секций соответствовали заявленной теме, например: «The Anthropology of Innovation: Economies of Creativity and Strategic Discovery» («Антропология инноваций: экономика креативности и стратегических открытий»), «Partial Evidence, Public Relations» («Частичные данные, связи с общественностью»), «Other Writing Genres: Exploring the Anthropological Production of Textual Evidence» («Разнообразие письменных жанров: исследуя антропологическое производство текстуального свидетельствования»). Некоторые специализированные секции также затрагивали аспекты, обозначенные в теме конференции; в работе одной из таких секций, которая называлась «Ethnography, Exhumation, Evidence» («Этнография, эксгумация, свидетельство») и была посвящена методологическим и этическим аспектам современной этнографии, приняла участие автор данного обзора.

По традиции, все пять дней мероприятия складывались из множества параллельных сессий, работавших, за исключением последнего дня конференции - воскресенья, с раннего утра до позднего вечера. Высокое качество и актуальность параллельных сессий делали выбор между ними почти невозможным, поэтому некоторые группы, например, Общество визуальной антропологии, начинали свои мероприятия накануне, за день до официального начала конференции, чтобы избежать подобных проблем с посещением и интегрировать в программу сессии, рассчитанные на полный день. Помимо обычных круглых столов и сессий с докладами, использовались и другие форматы: встречи сообществ и групп по интересам, обучающие семинары, инсталляции, выставки, ярмарки вакансий и проч.

В этом обзоре уделено внимание трём моментам, которые, на мой взгляд, отличают рассматриваемое мероприятие от его аналогов: (1) масштаб конференции; (2) ориентация на карьеру и (3) некоторые аспекты, касающиеся позиции исследователя.

Масштаб - визитная карточка конференции. В этом году ассоциация заявила о 750 сессиях и более чем 6000 профессиональных участниках со всего мира. Чтобы оценить, насколько это грандиозное событие, можно познакомиться с электронной версией программы. Перечни сессий того или иного общества вполне могут составить отдельную профильную конференцию, но проведение всех секций в одном месте помогает специалистам в разных областях взаимодействовать, что, несомненно, способствует развитию дисциплины.

В рамках конференции также реализовывались различные виды прямой поддержки карьеры антрополога. Для начинающих были организованы многочисленные образовательные мероприятия, в том числе помогающие решить практические задачи («That Almost Finished Journal Article» — «Та самая почти законченная статья»; «How to Write a Grant Proposal» — «Как написать заявку на грант»; «How to Find an Academic Job» — «Как найти академическую работу»), а также методические («Теaching Anthro» — «Преподавание антропологии»; «Introduction to Social Network Analysis» — «Введение в сетевой анализ»; «Introduction to Text Analysis» — «Введение в текстовый анализ») и многие другие. Общедоступны и бесплатны в рамках конференции индивидуальные менторские сессии. Организуются встречи с представителями университетов для тех, кто рассматривает возможность получения степени $\mathrm{PhD}$, и ярмарки вакансий для тех, кто уже заканчивает учёбу. Нужно отметить, что неформальное общение с представителями будущего работодателя (networking) не менее важно, чем последующие формальные процедуры, а зачастую именно оно бывает определяющим. Встречи со знакомыми часто повод для совместной фрустрации по поводу переизбытка кадров и сложности нахождения постоянной позиции в университете. Небольшой, но растущей тенденцией является попытка выхода антропологов за пределы академии, появление на конференции представителей компаний, таких как Intel и Microsoft, принимающих непосредственное участие в работе сессий. 
Тем, кто уже имеет постоянную позицию (tenure track), посещение конференции предлагает не только возможность для выступления и общения с коллегами, но и многочисленные профессиональные знаки поощрения. Я присутствовала на награждении членов Общества медицинских антропологов. Церемония предполагала довольно разнообразные способы поощрения - от мини-грантов за лучшие студенческие статьи до признания пожизненных заслуг перед наукой тех, кто отдал ей десятилетия и имеет значимые достижения. Что касается признания пожизненных заслуг, то такая оценка деятельности содержит сильный эмоциональный момент: члены профессионального сообщества могут видеть, что способен сделать один выдающийся человек.

Наиболее интересный для автора статьи аспект, оформившийся по итогам конференции, — вариативность и динамика позиции антрополога как исследователя. В специальной литературе часто встречается ситуация, когда антрополог представляет интересы того, кого он изучает, и встаёт на его защиту. В настоящее время можно наблюдать, каким образом продолжает развиваться метод: появляются автоэтнография, текстуальная или визуальная, переходящая в литературное или художественное творчество, мультисенсорные проекты, проекты на пересечении антропологии и перформанса. В качестве примеров можно привести доклад «The Anxiety of Writing» («Беспокойство письма») Рут Бехар, проект «Ethnographic Terminalia» («Этнографическая терминалия») и многие другие проекты исследователей и коллективов, стремящихся передать обществу определённый опыт и экспериментирующих с форматами его передачи.

Причины поиска и экспериментов кроются в том числе в социальной актуальности, которая всё чаще выходит на первое место. Выбираются темы, которые волнуют многих. Например, в этом году на конференции с почётными лекциями выступили Мелисса Харрис-Перри и Франс де Вааль. Открывающая лекция Харрис-Перри была посвящена результатам выборов в США и называлась «What Just Happened? Making Sense of the Election and Social Policy Priorities in the Post-Obama Era» («Что произошло? Смысл прошедших выборов и приоритеты социальной политики в эпоху после Обамы»). Эта тема стала наиболее обсуждаемой в кулуарах конференции. Завершающая лекция приматолога и этолога де Вааля «On the Myth of Human Cooperation as a "Huge Anomaly"» («По поводу мифа о человеческой кооперации как о “большой аномалии”») касалась социального взаимодействия.

Важной для антропологов становится возможность говорить с аудиторией вне профессионального круга и за рамками принятой процедуры производства научного знания. В качестве примера можно привести прошедшую на конференции пленарную панель «Translating Anthropology, Talking to Others» («Транслируя антропологию, разговаривая с другими»). Традиция обращения антропологов к изучению массовой коммуникации является давней, но, похоже, со временем в глазах сообщества она обретёт всё больший смысл и эмоциональный подтекст. В 2017 г. конференция будет посвящена активной позиции «антропологического расследования, трансляции, влияния и действия» ${ }^{2}$; её название формулируется следующим образом: «Anthropology Matters!» — «Антропология имеет значение!».

Возрастающее значение коммуникации антропологов с широкой аудиторией обусловлено, скорее всего, не столько коммуникационной политикой ассоциации, спущенной сверху, сколько необходимостью соответствия всё яснее звучащему запросу со стороны профессионального сообщества. Тема часто обсуждается на встречах и в личных беседах, создаются сообщества и ресурсы, поддерживающие её. Запросу отвечают проект «Writing with Light» («Светопись»), который осуществляется совместно двумя журналами, издаваемыми Американской антропологической ассоциацией, и посвящён жанру фотоэссе, а также проект в области науки, медицины и антропологии «Somatosphere» («Соматосфера»), который активно продвигается в социальных сетях.

2 URL http://www.anthropology-news.org/index.php/2016/11/22/116th-aaa-annual-meeting-call-for-papers 
Что касается социальных сетей, то они также часто были предметом обсуждения в рамках конференции - как в сугубо практических целях, так и в качестве поля антропологического исследования (например, сессия «Evaluating the Promises of Social Media» - «Оценивая перспективы социальных медиа» с участием «звёзд» цифровой антропологии Дэниела Миллера и Хизер Хорст). В рамках вечерней бизнес-встречи DANG (Digital Anthropology Interest Group) Дэниел Миллер также прочёл лекцию, презентующую специалистам по цифровой антропологии проект «Why We Post?» («Зачем мы постим в социальных сетях?»).

Проект «Why We Post?» посвящён исследованию социальных медиа и проводился командой антропологов одновременно в нескольких странах. Полевая работа длилась 15 месяцев, по её результатам были выпущены (и продолжают выпускаться) многочисленные монографии. Представляя результаты проекта, Миллер ориентируется не только на традиционный для антропологии академический круг читателей. Был создан сайт, где результаты исследования представлены короткими видеороликами и мемами, а ключевая информация доступна на многих языках. Также по результатам проекта был создан учебный курс, который проводится три раза в год. Все материалы, включая книги, бесплатны и доступны всем желающим на сайте проекта «Why We Post?»33.

Миллер вводит для понимания социальных медиа новый термин - scalable sociality («масштабируемая социальность»). Речь идёт об использовании различных платформ для коммуникации с группами, которые пользователь сам настраивает по количеству, составу и типу контента, заполняя, таким образом, пространство между публичными и частными коммуникациями. География проекта позволяет делать выводы о том, что социальные сети используются в разных обществах по-разному. Но в исследовании представлены также общие выводы, часть которых кажется очевидной, другие же не совпадают с часто встречающимися экспертными оценками и даже противоречат им. Ниже приведём несколько примеров полученных выводов:

— социальные медиа не делают нас более индивидуалистичными;

- некоторых людей социальные медиа не отвлекают от обучения; социальные медиа и есть обучение;

- публичные социальные медиа консервативны;

- социальные медиа не делают мир более гомогенным;

- мемы стали моральной полицией жизни в сети;

- мы привыкли просто разговаривать, сейчас же мы разговариваем фотографиями.

Всего по итогам проекта команда исследователей предлагает 15 общих выводов об использовании социальных медиа. Не меньший интерес представляют специализированные материалы по каждому из изучаемых направлений: промышленный Китай, сельский Китай, юго-восточная Турция, север Чили, остров Тринидад, южная Англия, северо-восточный регион Бразилии, южная Италия. По каждому направлению исследования выпущена или планируется книга, а также создан отдельный сайт, где можно посмотреть соответствующие видеосюжеты.

Миллер отмечает, что часто, практически во всех случаях, гипотезы, с которыми антропологи отправлялись в поле, не оправдывались, и на выходе складывались совершенно новые представления о том, как социальные медиа работают в реальности. Материалы проекта заслуживают внимания и могут быть интересны тем, кто занимается социальными медиа в самых разных областях.

Возвращаясь к практической стороне использования социальных сетей, можно отметить, что страницы в Facebook есть и у самой Американской антропологической ассоциации, и у отдельных сообществ

3 URL: http://www.ucl.ac.uk/ucl-press/why-we-post 
(например, у Общества антропологии сознания), а также у групп по интересам (например, у группы «Science, Technology and Medicine Interest Group» - «Наука, технология и медицина», существующей в рамках Общества медицинской антропологии). Тематические блоги в широком понимании этого формата - с дальнейшими репостами в социальных сетях — планируются при обновлении существующих ресурсов. На одной из прошлых конференций Пол Столлер, известный антрополог, ведущий колонку в американском интернет-издании «The Huffington Post», имеющем многомиллионную аудиторию, провёл для начинающих однодневный обучающий семинар, посвящённый блогерству. Создание контента нового типа становится важной задачей, которая активно обсуждается профессиональным сообществом антропологов.

Очевидно, что посещение конференции оказывается полезным сразу по многим причинам: это возможность наблюдать за развитием профессионального сообщества, знакомиться с актуальными направлениями в антропологии и вопросами методологии, а также получить широкую обратную связь относительно собственных исследовательских проектов. 


\section{CONFERENCES}

\section{Elena Sokolova \\ Evidencing Anthropology}

\section{5th Annual Meeting of the American Anthropological Association, 16-20 November, 2016, Minneapolis, MN. USA}

SOKOLOVA, Elena -

Postgraduate student, the Institute for Ethnography and Anthropology, Russian Academy of Science. Address: 32a Leninsky prospect, Moscow, 119991, Russian Federation.

Email: elena.k.sokolova@ gmail.com

\section{Abstract}

The Annual Meeting of the American Anthropological Association is one of the biggest international events in anthropology. Judging by the association's website, the event offers 750 sessions and includes more than 6,000 participants from all over the world. It is supported by key professional societies, such as the Society for Cultural Anthropology, as well as by numerous special interest groups, sections, and committees.

This article review covers the thematic aspects of the conference; the program's features, including the scale of the meeting and a focus on anthropologic careers; the attitude of the professional community towards an anthropologist's

role in society and shifts in this attitude; changing aspects of ethnographic methods; and finally some additional observations made by the author during the 115th Annual Meeting of the American Anthropological Association entitled "Evidence. Accident. Discovery," held in Minneapolis in November 2016. Attention is paid to educational programs within the community of anthropologists, the practical importance of informal communication at the conference, and the further exploration of public media tools — mainly digital—such as social networks and blogs.

The next Annual Meeting, "Anthropology Matters!" will further promote the active social participation of anthropologists and proceed with "anthropological investigation, translation, influence and action." This conference matters: it is a great opportunity to stay informed on the actual directions that anthropology and its methodology are taking and it is also a helpful tool to collect diverse professional feedback on anthropological research projects.

Keywords: anthropologist; anthropology; ethnography; the American Anthropological Association; conference; education; career; blog; social networks.

Citation: Sokolova E. (2017) Svideteli antropologii [Evidencing Anthropology]. 115th Annual Meeting of the American Anthropological Association, 16-20 November, 2016. Minneapolis, MN. USA. Journal of Economic Sociology = Ekonomicheskaya sotsiologiya, vol. 18, no 1, pp. 104-109. Available at: https://ecsoc.hse. $\mathrm{ru} / 2017-18-1 . \mathrm{html}$ (in Russian). 


\section{BEYOND BORDERS}

\section{Vladimir Zhdanov \\ Post-Authoritarian Devolution: The Case of the First Italian Republic}

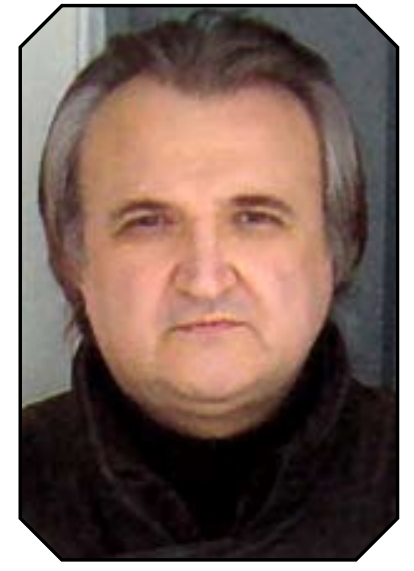

ZHDANOV, Vladimir MPA, Ph.D. (History), Ph.D. (Political Science), Independent scholar. Address: 990 North Pleasant St. Amherst, MA 01002, USA.

\section{Email:}

v.a.zhdanov100@ gmail.com
Based on the comparative analysis methodology in its case study form, this article examines the origins, the design, and the consequences of territorial arrangements in Italy, i.e. a country in which settling the stateness problem coincided with the process of post-authoritarian transformation. This experience - particularly the pacted transition (although it was not explicitly pronounced in Italy despite the fact that the state never witnessed any post-war anti-fascist lustration of bureaucracy) - was later used as an example for the Spanish model of democratic reforms, which in turn became paradigmatic. This article traces the long-lasting impact of the historic bloc between the industrial bourgeoisie of the Italian North and the landlords of the Italian South (Mezzogiorno) that contributed to the conservation of the socioeconomic backwardness of the latter. Special attention is given to the influence of the structural constraints of international bipolarity that laid down the external framework of the so-called "Italian anomaly", that is, the lack for almost half a century left-wing and right-wing political parties'alteration in power. This anomaly delayed Italian regionalization despite its having been envisaged in the constitution. However, the objective socioeconomic demands of a welfare state created possibilities for the birth of regions in the early 1970s. The emergence of the Northern League gave a new dimension to Italian politics by radically reshaping its traditional structures. These developments, taken together with the cleansing of a corrupted Italian political class, the referendum of 1993, and the new electoral law ultimately caused the demise of the First Republic.

Keywords: devolution; nationalism; regionalization; Italy; political anomaly; special statute regions; ordinary regions; the Northern League.

\section{Introduction}

Devolution means the emergence of regional political autonomy in relation to a center, an autonomy which "consists of a capacity to take decisions and to implement them on the basis of adequate resources" [Newton, Donaghy 1997: 123]. Contrary to federalism, in which the authority of different territorial levels of power is secured by a constitution and cannot be changed unilaterally, devolution reflects the more protagonistic character of a center, which retains the right to interfere in regions' activities [Bogdanor 1979: 2]. As the political expression of regionalization, that is, the reaction of a central government to regionalism (i.e., the demands of regions for a larger share of control over their territories), modern European devolution depends upon the following set of factors.

First is the factor of ethnic (or exclusive) and civil (or economic) nationalism. The latter is the feature of a more advanced level of civil society, which rejects 
ethnic nationalism and its rigid definition of ethnicity. Civil nationalism ascribes decisive meaning to the right of people to choose their nationality according to their affiliation with the culture and history of a given nation [Keating 1996: 1-7].

Secondly, devolution may be regarded as an immanent feature of modern political development which is linked to the ideology of decentralization, especially in countries that passed through the stage of authoritarianism [Baldi 2006: 28]. The "third wave" of democratization, launched by the Portuguese revolution of 1974, enabled these demands, latently ripened in the previous decades. An example is the Spanish model of democratic transition, which in fact became paradigmatic in this respect [Linz, Stepan 1996: 87].

Thirdly, it was the development of a welfare state and the subsequent rise of its social functions that demanded more rigorous economic planning [Baldi 2006: 23-26]. The number and volume of these functions and their financing were growing faster at the regional level than at the national one. The demand for social services led to the overburdening of welfare state, which negatively affected the efficiency of governing. Under these circumstances, the center began to regard civilized forms of nationalism not as an opponent but sometimes as an ally capable of taking on some administrative and even political functions. This development caused a transformation of the political system from one in which different territorial levels of power were acting rather independently from each other, to a system of mutual interdependence [Ocaña 1989: 89].

Fourthly, the rise of a welfare state caused an explosive growth of interest groups and ushered in the relative decline of political parties. The redistribution of authority between different territorial levels of government seriously affected the distribution of authority between political institutions, as well as the influence of various interest groups [Giordano 2000: 451-452; Wilson 2015: 186]. The peculiarity of the Italian case "was that party structures, interest associations and public agricultural and industrial institutions were all linked together in a complex decision-making structure in which the parties played a central role" despite "the fact that it lacked ... the possibility for all political parties to establish alliances and to be in government" [Morlino 2013: 342].

Last, but not least, is the factor of European integration that went along with devolution in the now-EU member-states. Since the 1970s, the EEC has had programs financing European sub-national governments: "the European Union is part of a system of multi-level governance which is driven by identity politics as well as by functional and distributional pressures" [Hooghe, Marks 2008: 23].

In Italy, which along with Spain represents the most suitable subject for a focused comparison of Russian politics in its 'most similar' research design due to the parallels of their historical developments, political cultures and institutions rooted in the authoritarian past, along with the role of the national center as a protagonist, led to the asymmetrical distribution of power and administrative capacities among political entities belonging to the same territorial level. The Italian and Spanish solutions to regional problems present the most interesting example of regionalization for Russia in the face of the revival of conflict between the center and the periphery as one of the main indicators of a systemic crisis. In the process of devolution, the Italian state successfully evolved from its unitary and highly centralized form into one that reflects a substantial degree of decentralization, and although it is not really federal, several federalization projects have developed there in recent decades.

Italian devolution preceded the regional reforms in Spain that proceeded there after the demise of the Franco regime, and similarly, the Italian regional state was a form of political compromise that could be placed at some point between the poles of a highly centralized state and a confederation. This point's coordinates were determined by a specific combination of different elites' strategies, which to a great extent were determined by elites' identities. 


\section{Historical Background}

History is non-linear and path-dependent. It is marked by "points of no return" - the intersections of several alternatives of possible historical development - in which the future is especially vulnerable even to minor decisions made by the factions of political class. Each of these alternatives is backed by specific combinations of the elites' strategies. The modern history of Italy is generally seen to have had six crossing points: (1) the Risorgimento - the creation of a unified Italian state under the hegemony of Piedmont; (2) the Giolitti era (1901-1914) - the unsuccessful attempt to broaden the social basis of the Italian state; (3) the early1920s and the rise of the Fascist regime; (4) the fall of the Fascist regime and the emergence of democratic Italy; (5) the rise of the welfare state; and (6) the crisis of the First and the birth of the Second Italian Republic. Of these points of no return, three (the Risorgimento and the rise and fall of the First Italian Republic) most strongly correlate to the dichotomy of centralism-decentralism in Italian politics.

The unification of Italy was not a spontaneous popular movement, but a deliberate, and essentially military effort, to build a nation-state. By taking advantage of many regional conflicts happening at the time, the Risorgimento was able to co-opt the support of strategically important local elites [Mack Smith 1997: 51]. Unification resulted in neither the demolition of traditional political and economic structures nor their radical modification; rather, the new Italian state was a conglomerate of different territories and social systems. The annexation of the Neapolitan Kingdom and the Papal States meant that this conglomerate would face such explosive social and political problems as "the Southern Question" and "the Vatican Question."2

The industrial bourgeoisie of the North was interested in the expansion of the national market, in the preservation of their monopoly over industrial production, and the complete elimination of southern manufacturing. The politics of the southern landlords aimed at the preservation of the semi-feudal socioeconomic relations present in southern villages, the protection of their property rights and privileges, and last but not least, the maintenance of high grain prices and land rents. The political alliance of elites with such mutually complementary interests eliminated the possibility of a radical reform of traditional structures in the South. The main political actors of the Mezzogiorno were more inclined to reserve the narrow internal market for the privileged groups than encourage the rapid modernization of the Italian economy and society. The national political class - consisting of an alliance between the northern bourgeoisie and southern landowners - thought that its interests could be better secured in a highly centralized state. This historic bloc thereby gave birth to the conservative bias of Italian stateness [Weibel 1971: 20-21]. The latter took the form of a modern unitary state in which the center completely dominated the periphery. ${ }^{3}$

In a narrow sense, it was the price the southern landlords were willing to pay for the suppression of peasant uprisings. From a broader perspective, it was a typical case of internal colonialism, where the main societal actors of the national core (the North) formed an alliance with the main societal actors of the periphery (the South) to boost the economic growth of the former by preserving the socioeconomic and political status quo of the latter. Over the centuries, southern elites had developed forms of compromises with authorities in ex-

1 "The Southern Question" refers to the economic, social, and cultural backwardness of the Italian South, which emerged as the result of the diverse evolutionary paths along which different Italian territories developed throughout history. As Mack Smith explained: 'The Southern Question has been the greatest manifestation of regionalism in modern Italian history, for it has perpetuated the division of Italians up into nordici and sudici' [Mack Smith 1974: 135].

2 "The Vatican Question" refers to the problem of relationships between the Italian state and Catholics in general, and the Vatican in particular. This problem began with the forced annexation of the Papal States, which laid down the basis for a long period of Vatican hostility towards the Italian state.

3 "Both the constitution of the kingdom, with its English-type parliament, and the administration, with its French-type centralization, stemmed from Piedmont" [Hearder 1983: 246]. 
change for privileges. The practice of transformismo ${ }^{4}$ and the clientelist links between politicians and local notables were emerging at an ever-increasing rate as the social basis for the governing coalitions in Rome [Hine 1993: 15]. The inclusion of conservative local elites in the policy-making process at the national level became the most serious hindrance to the modernization of the Italian South.

From the very moment of unification two extremely different types of society and polity-in the form of the traditional society of the South and the much more dynamic capitalist North-began to interact as a complex system of economic, social, and political interdependence. After unification, the economic and social diversity of the formerly independent Italian states resulted in polarization (due to the mutual opposition of the elements of development and backwardness) and in the emergence of the so-called dualist model, which became the basic component of further socioeconomic, cultural, and political developments. ${ }^{5}$ Because of its narrow social basis, the Italian state of that period had very limited capacity for political maneuvering and lacked effective mechanisms to extinguish political conflicts. The state constantly fluctuated between the extremes of liberalism (with its heyday during the Giolitti era) and the ever-growing popularity of the idea of a strong state, which found its full expression during the Fascist regime.

The post-World War I settlement further contributed to Italian heterogeneity. In accordance with the SaintGermaine peace treaty of 10 September 1919, Italy annexed the southern provinces of the Austro-Hungarian Empire, i.e., Alto Adige (South Tyrol) and Venezia Giulia, with their predominantly non-Italian populations (e.g., Italians constituted only $16 \%$ of the people living in South Tyrol) which had quite different systems of government that could hardly conform to rigid Italian centralism. This meant that Italian stateness would encounter additional challenges in the future, since the populations of these provinces were neither ready to renounce their traditional local autonomy nor reject their cultural identity [Weibel 1971: 26].

In the sixty years that followed the Risorgimento, the modes of strategic games of elites in Turin (and later in Rome) with peripheral elites passed through all possible varieties of accommodating the latter (the pure patrimonial form of state-building during the Risorgimento, the special legislation for the South, the unsuccessful attempts during the Giolitti era to broaden the social spectrum of the main political actors, and finally - the restoration of the unilateral treatment of territorial elites under the Mussolini regime). It should be noted here that the corporatist institutional arrangements of the Fascist state, which buttressed the strategic games of the political core with the functional elites of Italian society, completely replaced the strategic games of the center with the elites of periphery.

\section{The First Italian Republic (1948-1994)}

The fall of the Fascist regime and the end of the Second World War instigated the democratic transformation of Italy. Fascist over-centralization had placed the question of Italian democratization in a very dramatic context, but it was clear that the country needed a new constitutional and institutional framework. On 2 June 1946, a popular referendum decided on the form that the Italian state would take; the monarchy was narrowly abolished by 12.7 million people (while 10.7 million supported it) and the Republic was proclaimed [Lepre 2004:

4 In the Italian political context, transformismo referred to the parliamentary practice of continuous vote-trading between the government and the opposition. In particular, it was widely practiced by southern deputies who supported any political party in power in exchange for the freedom of action in the South. In essence, transformismo became the political expression of the historic bloc [Keating 1988: 118].

5 Dualism means the existence of a complex socioeconomic structure in which the opposing elements of backwardness and modernity and the traditional agrarian and modern industrial sectors of the economy are highly mutually interdependent and play complementary roles. By the time of Risorgimento, dualism was linked to the existence of extreme economic, social, and cultural diversity in the Italian states, and was further strengthened by the peculiarities of the unification process, i.e., the social alliance of the northern bourgeoisie and southern landlords [Tarrow 1977: 11-24]. 
72]. The referendum confirmed once again the existence of two Italies - the North and the South — which remained rather different in their political preferences; for example, in the South the majority of the votes favored the monarchy. The referendum coincided with the elections to the Constitutional Assembly, which gave the qualified majority to three main parties: the Christian Democrats (DC) received $35.1 \%$ of the vote, the Socialists (PSI) 20.7\%, and the Communists (PCI) received 18.9\% of the vote [Kogan 1983: 25-26].

But by the end of 1945, the anti-Fascist coalition had slowly begun to disintegrate. The catalyst for this breakdown was the question of whether to restore the pre-Fascist form of the state or to pursue the devolution of power. Regionalization as a means of altering the state's structure gradually gained broad popular support. However, there was no consensus about how it might be carried out. The reformation of the Italian state involved three main factors: (1) the separatist movements present on the islands and in border regions; (2) the need to increase popular political participation as one of the cornerstones of a democracy; and (3) overcoming the incomplete unification that should be manifested in the comprehensive development of the South [Keating 1988: 135].

This internal political cleavage of Italian polity was exacerbated by the external factors, particularly the beginning of the Cold War. The expulsion of the Communists and Socialists from the coalition government in 1947, which was a precondition for receiving US economic aid [Lepre 2004: 87-88], marked the beginning of the so-called Italian 'political anomaly' (a.k.a., the "imperfect two-party system," "polarized pluralism," and a "blocked democracy") [Briquet 1997: 49-50]. Its basic feature consisted of the absence of a systemic opposition to balance the ruling party while also being recognized as a reliable partner in strategic political games. Such a 'political anomaly' was described as conventio ad excludendum (a convention according to which one or more political parties were considered unfit to participate in the cabinet), which "thwarted the functioning of Italy's postwar parliamentary democracy, that is, away from being a system that allows for alternation and thus meaningful debate in government, between majority and opposition" [Ventresca 2004: 150].

The parties' programmatic stances on the regional issue fitted into highly ideological interpretations of Italian history and various strategies of socioeconomic and political developments. Beneath these elaborate strategies were assessments of each party's relative political capacity and estimations of the possibility of controlling the government in Rome. Rapid normalization also implied a pact with the existing bureaucracy, which remained intact after the fall of Fascism [Cassese, Torchia 1993: 96].

\section{Constitutional Framework}

On 22 December 1947, the Constitutional Assembly adopted the Constitution of the Italian Republic that went into effect on 1 January 1948. It was a progressive constitution as the outcome of a complex negotiation between different political actors who had played decisive roles in the Resistance. As would happen three decades later in Spain, the founding fathers of the Italian Republic tried to delay for as long as possible finding solutions to many of Italy's political problems, among them the form of Italian stateness. The constitution formally declared the decentralization of state power and its devolution to the regions. It defined the broad spectrum of regional competencies in finance and taxation, agrarian and social policies, and economic development and planning. This way, Italian devolution went beyond the limits of ordinary functional decentralization, but it did not come even close to a federal state. Without destroying the unitary state, the regions were expected to counteract the over-centralization, uniformity, and lack of flexibility of the national government by permitting some degree of political autonomy [Baldi 2006: 81-82].

Italian asymmetrical stateness was largely based on the specific historical circumstances that played out during the Resistance, mainly centered on the existence of separatist movements on the geographical fringes of Italy, particularly in Sicily [Perdomo 2001: 76]. The Constitutional Assembly de facto recognized the special 
character of these territories, thus drastically reducing the scope for political maneuvering in the subsequent discussions on the form that Italian stateness would take [Baldi 2006: 80-81]. The confirmation of a Sicilian special statute on 15 May 1946 reduced this scope for political maneuvering even further. The creation of the special regions made the initial regionalization of Italy inevitable [Bifulco 2004: 10-12]. The hastiness and aptness of these decisions were much criticized later, because insufficient coordination of the special statutes with the Constitution and the lack of clearly defined relationships between Rome and the special regions set the scene for many conflicts.

The spatial distribution of parties' domination in Italy was one of the major factors that shaped the historically concrete form of Italian stateness. The PCI's dominance in the central regions of Italy determined its insistence on the creation of strong regions, thus motivating the Christian Democratic reluctance to pass the enabling legislation. The institutionalization of regions in these conditions would mean that Rome would have fewer channels to control the politics in the opposition-dominated regions. If the DC were sure it could control the regional governments exclusively through the party channels it would permit the regions to get more autonomy. But the existence of a geographically concentrated opposition substantially contributed to the centralist tendencies of the Italian political system [Baldi, Baldini 2008: 77-78].

The Constitution of 1948 defined Italy as a 'regional unitary state', i.e., an intermediary form between unitary and federal stateness. While proclaiming the unity and indivisibility of Italy it also stressed the necessity of political decentralization and local self-governance. Articles 114-127 and 130-133 recognized regions as an immanent part of the Italian state without recognizing their sovereignty. The whole idea of the regional state was based on the Catholic principle of subsidiarity, i.e., the strict hierarchy of levels with clearly defined competencies [Bifulco 2004: 34-37]. All regional legislation, i.e., that which was issued not only by the ordinary regions but also by the special ones, was subjected to the preliminary control of the national government to ensure its compatibility with regional competencies, the articles of the Italian Constitution, basic national interests, and the interests of other regions.

Due to specific historical starting conditions, i.e., the existence of regions with special statutes (Sicily, Sardinia, Trentino-Alto Adige, and Valle d'Aosta), the stateness of the Italian republic emerged in the form of an asymmetrical regional state in the same manner as it would later come into being in Spain. According to article 116, these regions had "specific forms and conditions of autonomy" which were determined by different statutes. Special regions have got their own legislative power in the areas of economic development, finance, taxation, social services, insurance, labor relations, and higher education. While the special regions had broad competencies in finance and taxation, the competencies of ordinary ones were limited in these areas to a minimum. The latter had the right to impose some minor taxes as well as to impose a regional addition to the national taxes within limits defined by Rome. However, the main difference between these regions and the ordinary ones manifested itself in the fact that contrary to the latter, which possessed only concurrent legislation, i.e., the legislation that was restricted by the corresponding national legislation, the former had the right to "exclusive legislation" which varies substantially from region to region [Weibel 1971: 365-417].

Title V of the Constitution stated that elections to all regional legislatures were to be carried out within a year after its adoption. It envisaged that within a three-year period, all Italian laws would have been revised according to the new territorial framework. However, up until 1970 these constitutional articles were a dead letter: there was no real regional stratum in Italy, with the exception of the special regions. The formation of ordinary regions was postponed for two decades. The landslide victory of the Christian Democrats at the parliamentary elections of 1948 led to their decision to ignore the constitutional provisions on regionalization in order to secure the party's political hegemony - the position that was adamantly supported by the national bureaucracy, which did not endure the process of antifascist lustration [Di Palma 1982: 122]. 
The regional state in Italy was the result of an unbalanced compromise among the country's main political actors that was marked from the very beginning by serious contradictions. The ambiguity of the constitutional provisions for the regions encouraged each political party to interpret the regional reform in a manner that would enhance their own powers. This compromise was further complicated by the delay of regionalization until 1970 when it reflected a new political balance. Still, the Constitution of 1948 meant more than just the abolition of monarchy - it provided the constitutional framework for the territorial modernization of the country. Since the unification of 1861, the Constitution represented the most important turning point in Italian history [Ciuffoletti 1994: vii-viii].

Although comprehensive regional reform was delayed almost indefinitely, the special regions were established as scheduled. All of them were regions on the Italian periphery that could be distinguished by their rather visible and particular socioeconomic (Sicily and Sardinia), cultural, and linguistic traditions (TrentinoAlto Adige and Valle d'Aosta). More important than this social background was the influence of an additional set of political actors in these regions in the form of separatist movements and foreign powers [Galli, Prandi 1970: 27].

Even more crucial was the fact that, contrary to their Spanish counterparts (i.e., the Basque Country and Catalonia, which, in addition to their obvious cultural-linguistic differences represent the most economically dynamic regions of Spain) and due to their small geographic and demographic sizes, Trentino-Alto Adige, Valle d'Aosta, and Friuli-Venezia Giulia (the latter was established in 1963 [Baldi, Baldini 2008: 79]) failed to develop strong regionalist parties capable of playing serious roles in the political coalitions in the lower house of the Italian Parliament. Moreover, having been incapacitated in its role as a territorially representative body, the Senate was unable to support the interests of these regions institutionally [Palermo, Wilson 2014: 511].

In the absence of strong regional parties and institutionalized regional representation by the upper house of the Italian Parliament, Italian devolution was held hostage by the balance of power between a variety of national political actors who used the former as additional leverage for their own political gain and not as the means to satisfy the demands of the regions [Ciuffoletti 1994: 165-166].

\section{The Southern Question}

Although the Italian constitution envisaged the creation of two types of regions — ordinary and special—in reality their formal differences were overshadowed by the much more obvious differences between two main Italian mega-regions: the North and the South. They represented two different models of interest aggregation: in the North, interests were voiced via interest groups and political parties, and in the South, this was achieved through clientelism, which was used by almost all political parties (with only one possible exception of the PCI).

Frightened by the possible revival of peripheral separatism that had already played the role of midwife in the birth of asymmetrical Italian stateness, the national political class responded to the unsolved problems of the South with official and unofficial policies and political tactics. Its actions - although formally denying the discretionary treatment of special (already existing) and ordinary (only existing on paper) regions - in reality treated different societal actors in these territories preferentially.

A new governmental agency aimed at the institutional substitution of political asymmetry among prospective regions with the asymmetry of policies towards the South was created in 1950 under the title of Cassa per il Mezzogiorno (Fund for the South) [Watson 1970: 10]. The establishment of the Cassa represented an alternative response of the national political class to the full-fledged regionalization of the southern regions which could have had unforeseen ramifications for Italian stateness. Under the rigid structural constraints of the Cold War, only this alternative was viable because no forms of popular representation at the local level could be accepted since they might have led to the abolition of the Italian political anomaly. 
Since 1950, the policy of providing special assistance to the South became one of the main factors behind the development of the modern system of political power and social control in Italy, both of which were based on the distribution of public spending. This new form of historic compromise resulted in further increasing the dependency of the South, which once again had to pay for the expansion of northern industries. Consequently, the political elites of southern Italy started regarding themselves as the intermediaries of this distributional policy [Tullio-Altan 2000: 154].

At the beginning, the special policies for southern development were mainly concentrated on the formation of industrial infrastructure. Later, the theory of the growth poles demanded large-scale interventions of the state in targeted regions [Kogan 1983: 138]. In Italy's particular political environment, the theory of the growth poles met the needs of southern local elites. Since these political bosses could not hinder the policies regarding the industrial development of the Mezzogiorno, they tried to support only selected programs that could be placed under their control. These policies were implemented to stimulate self-supporting growth-cycles through making investments into the industries that already had relatively well-developed infrastructure, thus permitting the state to step back from the market after correcting its imbalances. The special measures for the leveling of economic differentiation between Italian territories led to the permanent expansion of industrial installations in order to ensure the continuous influx of funds [Baudner, Bull 2013: 213-214].

Further development of the Mezzogiorno was marked by the extensive modernization of its social and cultural spheres. This was achieved through the further elaboration of clientelist political mechanisms that played the role of the territorial expression of transformismo. Regional authorities quickly became the immanent part of the patronage system. Moreover, the regional political dimension of the South was immediately occupied by traditional power mechanisms, based on the hegemony and clientelism of parties [Hopkin, Mastropaolo 2001: 155-158]. The spread of large-scale political corruption, which was based on the clientelist networks, was furthered by the polarization of political culture in the climate of the Cold War and through the sudden availability of financial resources for the purposes of reconstruction [Finley, Mack Smith, Duggan 1987: 221]. The inclusion of the Socialist Party in the governing coalition did not alter this political arrangement since the PSI soon became accustomed to the existing clientelist practices.

Political clientelism achieved its most developed form and penetrated all social spheres in southern Italy for only there did it find the best combination of historic peculiarities in which it could take root and flourish. It was the DC that became the nucleus of clientelism, where the notables of pre-war transformismo found their new political niche. The 1947 demise of the national unity government gave a new form to the old system of transformismo, in which the southern Italian notables of the DC played the role of intermediaries. This reincarnation of the old political elite took place within the framework of a still highly centralized state, whose new democratic institutions contributed to the establishment of additional clientelist channels.

The colonization of state and society by the DC was especially extensive in southern Italy. There, the Christian Democrats secured a monopoly over the mechanisms of power for the transfer of demand for favors. The political hegemony of the DC at the national level provided it with necessary resources [Finley, Mack Smith, Duggan 1987: 222]. The expansion of state intervention into socioeconomic matters in general and into the programs for the development of the Mezzogiorno in particular supplied this renovated clientelist structure with the new methods of the sottogoverno system. ${ }^{6}$ This change in the rules of the strategic games resulted in the blocking of the development process since self-sustaining growth in the Mezzogiorno would undermine the structures of dependence upon which the entire clientelist system was based.

6 Sottogoverno means the distribution of administrative positions in the governmental bodies proportionally to the relative political weight of the parties of the ruling coalition. Sottogoverno was an important element of partocrazia (the dominance of political parties). 
During the socioeconomic reconstruction of the 1950s, the clientelist system was also modernized and the individual relationships between patrons and clients were substituted by the mechanisms of the mass parties. The Christian Democrats established a special office for the political and organizational development of the backward territories, which transferred the control over southern politics and southern party organizations from the notables to political managers who operated under the direct control of politicians at the national level. This change produced a more efficient patronage system in which the old relaxed network of individual patrons was replaced by the party machinery controlled by Rome [Keating 1988: 142]. Voting was understood in this system not as a democratic act but as an expression of one's affiliation with a particular clientele [Della Porta 1997: 45].

The mass-party patronage system discouraged the collective representation of interests outside political parties or regionalist movements in the Mezzogiorno. The parties, which constituted the fundamental pillars of the Italian political system, were snatching up every attempt of institutional change, while turning them to their own advantage and blocking real political and administrative reforms. For instance, if implemented, the system of regional planning would undermine the very basis of DC power in the South, i.e. "the discretionary control of the distribution of credits and benefits and the dependence of communities and social groups upon the Party machine" [Keating 1988: 155].

The crippled functioning of public institutions and the inefficiency of public administration contributed to the spread of corruption, clientelism, and criminal favors on an even larger scale, and "the DC and its coalition partners plundered the bureaucracies for patronage" [Warner 2001: 138]. The citizens' trust in the ability of the state to guarantee their rights was considerably diminished by these developments. The latter reinforced the necessity to secure the privileged channels of access to public services. Ultimately, this led to the emergence of mechanisms of selective inclusion which shaped the circles of the privileged few who would be ready to pay and take the bribes, and exclude all others from participation [Della Porta 1997: 39].

The drawbacks of the planning process led to the lack of adequate precision in the targeting of socioeconomic goals. Moreover, the administration's planning incapacity led to the practice of last-minute political agreements or administrative improvisations, which undermined the strategy of long-term planning. The planning process was also subject to the pressure of local political groups that stipulated the provision of socioeconomic programs in the form of thousands of smaller sub-programs. This splitting substantially facilitated the misuse and abuse of public funds, while at the same time the exhaustion of available public resources and the political changes on the national level gradually deprived clientelism of its legitimacy.

The hardly pronounced willingness of southern regional political actors to make the regions an appropriate framework for their political activity to a large extent was caused by the absence of a developed regional selfidentity in the Mezzogiorno. Not until the mid-1960s - the preparation period for the comprehensive regionalization of Italy — was the southern question combined with political discussions about this new form of Italian stateness [Cassese, Torchia 1993: 96-97]. Although many factors that were usually regarded as the causes of political regionalism and regional nationalism — such as the increasing developmental differences, the growth of social tension, urbanization crises, and different historical traditions - were typical of Mezzogiorno, they did not lead in Southern Italy to the rise of noticeable peripheral regionalism during analyzed period.

The explanation for this historical anomaly should be primarily sought in the peculiarities of the Italian political system in the South in general and in southern political culture in particular. Southern Italy was distinguished by two political phenomena: on the one side there was a distinctive distancing from the state; on the other there was a widespread mentality of dependence that placed the central state as the guarantor of social welfare and development. Both phenomena were the elements of the clientelist system that connected the distant capital with individualistic, particularistic, and locally embedded interests. 


\section{The Birth of the Italian Regional State}

In the early 1960s a new concept of the regions emerged. To an ever-increasing extent, the regions were regarded as the instrument for consolidation of DC achievements, which were the result of its successful economic policy in the 1950s. The "economic miracle" of the 1950s and early 1960s permitted Italy to transform itself into a welfare state [Ferrera, Gualmini 2000: 188]. However, Christian Democrats became the victims of their own success: this new type of state caused an exponential increase in the government's functions and responsibilities. The old highly centralized system of governance could no longer cope with the problems of modern society and the welfare state. The functional requirements of the welfare state demanded a new administrative level between the provincial and the national ones [Cassese, Torchia 1993: 97].

Regionalization was the organizational response of the Italian political class to the contradictions inherent in an emerging welfare state in the new political environment, which showed that traditional forms of political alliances with local elites had exhausted their capacity. The national government needed to prove its reformist potential, and regional reform was found to be the most inexpensive response to political pressure that would not radically alter the existing government institutions [Baldi, Baldini 2008: 81-82].

Elections to the first regional councils became possible in June 1970 after both chambers of the Italian parliament had passed the regional electoral law in February 1968. But for the next two years, the regional governments had only nominal authority until Rome had completed the transfer of administrative personnel and financial competencies to the meso-level. Only then did the regional parliaments pass the statutes of ordinary regions in May-June 1971. The creation of ordinary regions was a decisive step in reforming the highly centralized Italian political system. This development added a broad new dimension in the forging of political coalitions. It was followed by a series of laws and decrees that delegated to regions the competencies that had previously belonged to the national government. Italian devolution was an attempt to create a new state that would bind all parts of the country in an extremely diverse socioeconomic and cultural environment. This diversity caused the multiple forms and scales of autonomy that were ascribed to the special regions, whereas the ordinary regions were given a homogeneous institutional and political-administrative structure [Mazzoleni 2009: 136-138].

Regionalization was regarded as one of the main tools to increase democratic participation and make economic planning more comprehensive. The regional reform in Italy also represented an attempt to avert the overloading of the central government and the over-expansion of the national bureaucracy while preserving the functions of the welfare state [Dente 1997: 199]. The latter was an especially difficult task in Italy, which lacked an adequate quantity of sufficiently trained modern bureaucracy. The transfer of the whole spectrum of Italian socioeconomic and political problems into a completely new territorial dimension was regarded by many representatives of the Italian political class as an effective tool aimed to compensate the inadequacies of administrative cadres. The solutions of these problems could be shifted to the regions while leaving the benefits of politics to the national stratum of Italian ruling elites [Cassese, Torchia 1993: 108]. Also, the Italian business community expected that the opening of the regional dimension would decrease and channel social tensions to the lower level [Chiaramonte 1998: 843]. Regional reform was also an attractive goal for the parties and political movements that either belonged to the opposition or were excluded from the ranks of the Italian political class [Putnam, Leonardi, Nanetti 1993: 20]. The strategies of political actors, which coincided in regionalization, were buttressed by the profoundly different ideologies and views of the regions. However, between 1968 and 1970 the activities of these actors reinforced each other and pointed towards the creation of regions as the way to overcome the Italian political crisis [Cassese, Torchia 1993: 97].

These strategies were supported by two major changes in the Italian economy and society. First, impressive economic growth made more resources available not only for the purposes of accumulation but also for distribution, for "pluralism and institutional polycentrism in Italy depends strongly on the availability of economic 
and financial resources; redistribution cannot be enforced simply by diminishing resources for one group in favour of another group, but only by giving more to every group, or at least maintaining the previous allocations" [Cassese, Torchia 1993: 96]. Second, it was through the profound changes in the realm of Italian political sub-cultures, where not only the authoritarian culture of the Fascist period gave way to democratic values, but also the erosion of traditional "white" sub-culture (upon which the entire Christian Democratic identity was based) took place. ${ }^{7}$

But the role of the regions in national political decision-making was severely restricted. The electoral districts continued to be formed on a provincial level. That is why the broad competencies that the state had in the regions were not balanced by the participation of the latter in national political decision-making and the national political class remained more interested in making connections with the provincial elites who had more leverage over the elections than their regional counterparts [Gold 2003: 52]. Although some degree of financial autonomy was envisaged in the Italian Constitution, in reality ordinary regions lacked almost any freedom in their financial operations. ${ }^{8}$ In 1993, the tax receipts from all three levels of local government in Italy—regional, provincial, and communal—accounted for only $3.7 \%$ of total tax revenues. ${ }^{9}$

The real devolution of competencies from the national level to the regions occurred only in the mid-1970s during the second phase of regionalization. After the remarkable victory of the Communists in the 1974 regional elections, the 'left alternative' and the 'historic compromise' between the PCI and the DC threatened to finally be realized [Kogan 1983: 289-291]. The united "regionalization front" that emerged at that time in the Italian Parliament was a coalition of various political forces from northern and southern Italy under the auspices of Lombardy (the progressive DC) and Emilia-Romagna (the PCI). These diverse political forces were backed by sympathetic media and public opinion as well as by the Ministry and the Inter-parliamentary Commission on the Regions [Putnam, Leonardi, Nanetti 1993: 21]. The convergence of these different forces led to the expansion of regional competencies in 1977.

The establishment of ordinary regions in the 1970s did not contribute much to the development of the South. Instead of the regionalization of Mezzogiorno leading to increased popular participation and transparency, it led to the formation of new political mediators who were oriented towards the satisfaction of their own interests. Above all, they used their control over public funds as the means of fabricating political consensus [Vannucci 1997: 55]. Instead of lessening the disparities between the Italian North and South, the reform actually intensified them, since the prosperous regions of the North got some respite from the "stultifying grasp of Rome" [Vannucci 1997: 61]. Meanwhile, the regions of the Mezzogiorno were still dependent upon the policies of the national government, which had in its ranks an impressive number of the southern political class members, and was not immune to the pressure of its regional counterparts and continued to pursue policies of economic redistribution and financial transfers to the Mezzogiorno.

During this period there were also several attempts to reform the policy for southern development. In 1986, the Cassa per il Mezzogiorno was replaced by the "Agency of the South." The elimination of the Cassa was instigated to demonstrate the rejection of the old centralized policies for southern development and the adoption of new integrated programs. The regions of the Mezzogiorno had to have the right of initiative in the sphere of southern modernization. Based on these initiatives, the central government together with the regions had to elaborate on three-year plans for their economic development [Gualini 2004: 83-84].

7 These changes, albeit to a lesser degree, also affected the "red" sub-culture of the Left due to the different mechanism of its generational socialization [Marletti 1997: 70].

8 "Most financial transfers from the national government to the regions were earmarked for specific programmes or projects, which gave central government the ability to insist on joint management of these resources" [Grote 1996: 260].

9 The overage revenues for the local governments were that time $12 \%$ for unitary states and $31.4 \%$ for federations [Gold 2003: 51]. 
By the time of the Second Republic, the Italian South still could not overcome the gap between it and the North despite forty years of the special policy for southern development. ${ }^{10}$ The South continued to be a protected market for northern industries [Trigilia 1993: 117]. But in the early 1990s, the logic of European integration and especially the prospects of participation in the EU's monetary union began to exert pressure on traditional forms of public budgeting in Italy, whose industrial policy and the policy for the development of the South were blamed by the other members the EU as a breach of fair competition. In the context of European integration, the collapse of the previous policies for southern development contributed to the dissolution of traditional mechanisms of political consensus, which in the past had served to ease social tensions.

Control over the rules of the political game and over public finances was still the prerogative of Rome, whose policies towards the regions were less based upon formal political strategies than they were on informal ones. The culturally superior northern regions possessed more economic and social resources that made them much more prepared than their southern counterparts to engage in successful political bargaining with Rome [Dente 1997: 198].

This cultural background led to the emergence of two different political styles: the northern regions oriented themselves towards horizontal political strategies, whereas the southern regions preferred vertical ones. While the former strongly favored the methods of collective actions on the horizontal level that actually took the form of a broad regional front, the southern regions favored the vertical strategies that prioritized their patrons at the national level [Putnam, Leonardi, Nanetti 1993: 23]. These political links to Rome that characterized southern Italy were further reinforced by government policies for support of the Mezzogiorno that promoted the transformation of the southern political structures of dependence into a culture of dependence. By the 1980s, it had become apparent that there were two different development models in Italy: while the northern economy was concentrated around industrial development, the economy of the South was oriented towards the distribution of economic resources and monetary transfers from Rome.

The slow progress of regionalization in Italy was caused by the leveling influence of a highly centralized Italian party system. In the 1970 s, the parties were much more strongly centralized than anybody could have predicted in 1948. The newly created regions immediately found themselves placed within a narrow political space between hierarchically structured, rigid all-Italian political parties, which were distinguished by their almost exclusively nation-oriented agendas, and traditionally strong provincial political structures [Desideri, Santantonio 1997: 96-97].

After the establishment of ordinary regions, the national parties restructured themselves according to this new framework and created their regional branches. But this development was not accompanied by a subsequent transfer of political capacities from the national and provincial levels. Instead, political and financial structures continued to privilege the national elites; public finance was the domain of the national parties while their regional counterparts were completely excluded from this lucrative sphere [Putnam, Leonardi, Nanetti 1993: 46]. These negative developments were much more visible in the South where the creation of regional branches of the national parties led to the establishment of additional channels of clientelist structures, which further contributed to the inefficiency of the governance in the Mezzogiorno, especially within ordinary regions.

It was the North that began to increasingly demonstrate its separatist inclinations. But these processes did not start right after the establishment of ordinary regions in 1970. With only a few political actors - like the South Tyrolean People's party - there was hardly a visible separatist movement during the 1970s. That changed in the late 1970s with the emergence of Liga Veneta (1979) and Lega Lombarda (1982) -later Movimento Lega

10 In the mid-1990s, $36 \%$ of the population resided in the South but its contribution to the Italian GNP was $25 \%$ and it only accounted for $9 \%$ of exports [Koff, Koff 2000: 5]. 
Nord (1989) — which would play a major role in the radical reshaping of traditional political structures in Italy [Gold 2003: 79-85]. Lega Lombarda emerged during the 1987 elections in Lombardy with a modest 2.7\% of the vote but only three years later it had secured $21 \%$ of the vote in the same region [Lotti 1997: 163]. It was the Northern League with its solid $25 \%$ of northern votes and $18.7 \%$ of the national ones at the parliamentary elections of 1992 that put an end to Italian politics as an exclusive game played by national political elites [Tullio-Altan 2000: 252].

The emergence of the League was the result of profound socioeconomic changes that were taking place in the Italian North throughout the 1970s. Firstly, it reflected the growth of the 'third Italy' in the northeastern part of the country, i.e., the development of export-oriented small and mid-sized businesses. Secondly, it demonstrated the continuous erosion of the "white" sub-culture that gave way to the growth of the new territorial type of identity [Marletti 1997: 70]. The success of the Northern League at the end of the 1980s was at least partly the result of the inefficient governance of Rome. During that time, the League actively supported the idea of broad federalism. For the League, the latter became synonymous with the new laissez-faire policies for the northern parts of the country while centralism was regarded as synonymous with southern parasitism [Bencardino 1997: 26]. The League questioned the ability of prosperous regions in the North to be the main generators of resources for financial transfers to Italian South [Ciuffoletti 1994: 176-177]. The concurrent economic crisis, which led to fiscal restrictions, was a substantial supporting factor for such criticism.

The parliamentary elections of 5-6 April 1992 were the last to be carried out on the basis of proportional representation. Despite staying within the limits of the First Republic political system, they played the role of the harbinger of political cataclysm. For the first time in history, the DC did not reach the threshold of 30\% of the votes, having been electorally deprived by the League [Lotti 1997: 167]. To reform the organizational structure of the regions, the new legislature and the coalition government on 23 July 1992 established the special bicameral commission (Bicamerale-I). On 27 October 1993, the commission presented its suggestions to the public. According to it, for the first time in Italian history the regions should have acquired a comprehensive system of self-governance and autonomous legislative, administrative, and financial powers which would have transformed them into real political autonomies [Ciuffoletti 1994: 185].

If implemented, this change to article 117 of the Constitution might have put an end to the asymmetrical nature of Italian regionalism. Contrary to the existing model of regionalism in which the national state discreetly delegated some of its competencies to the regions, it would be the latter that would transfer functions to the state that could not be performed at the regional level, i.e., foreign policy, national defense and national security, national finance, the guarantees of civil liberties, national economic planning and the basic welfare programs. These radical propositions were never implemented. Instead, there were only minor changes made to the regional electoral system in February 1995 [Pizzetti 1996: 238].

In the early 1990s, massive criticism of the special policies for the support of the Mezzogiorno came from across the entire Italian political spectrum. The abolition of traditional state interventions for the development of the South took place in 1993 under the joint pressure of the Italian Left and the Northern League. In 1993, the national government completely eliminated the traditional forms of the policy for southern development [Gualini 2004: 83-84]. Despite much justifiable criticism, the policy for southern development admittedly allowed the Mezzogiorno to overcome its economic isolation and to develop a basic infrastructure for further industrialization. However, at the same time it contributed to socioeconomic immobility in the South because it caused an increase in public wealth without a subsequent increase in economic productivity.

The analyzed period witnessed the steady transformation of weak corporatist institutional arrangements (whose temporary revival was caused in the postwar decades by the Italian political anomaly, which in its turn was a function of the rigid Cold War structural framework) into the abortive form of asymmetrical stateness. The 
latter was caused by the inability of regionalist parties to participate at the national level as well as the colonization of the Italian state by the Christian Democrats. Only by the end of the 1980s had the weak Italian form of asymmetrical stateness started to dissolve steadily under the pressure of three interconnected factors: the end of the Cold War, which led to the end of the Italian political anomaly, and the emergence of the Northern League that was capable of participating in strategic games at the national level because its political power was buttressed by the economic power of the northern regions.

\section{Italian Regions in the EU Context}

From the beginning of the ordinary regions, Rome was explicitly clear in its intentions to restrict their contact with the institutions of the European Community while the supra-national institutions of the latter became the supportive factor encouraging the development of Italian regions. The criteria for the transfer of administrative competencies to the regions, according to EEC guidelines, were set in Italy by Law N 382 (1975), which explicitly restricted their international activity [Condorelli 1986: 147-148]. This regulation prevented the Italian regions from institutionalizing their own representative bodies in Brussels in the same way as federal states did. However, despite these restrictions, the EEC exerted a shaping influence on the role of Italian regions. Since the late 1980s, regional policy has been an ever-increasing component in the activities of the European Commission [Keating 1988: 167].

The reforms of EU structural funds in the 1980s and early 1990s assigned to European regions a much more important role in the planning and transaction of the funds' programs than was initially intended. Although this development hardly gave Italian regions any substantial influence over their participation in the elaboration of EU structural policy, it increased their consulting role and improved their access to crucial information. The effective participation of Italian regions in the EEC regional policy primarily depended on their success in securing informal relationships with those ministries that were involved in Community's political decision-making. Among these ministries, a crucial role was played by the Inter-Ministerial Committee for Economic Planning (CIPE), charged with coordinating Italian policies in the EEC [Grote 1996: 262-266].

The Maastricht Treaty, which acknowledged the principle of subsidiarity, represented the climax of this development that indirectly assigned to the regions of Europe an important role in the new European order and brought a real institutional reform through establishing the Committee of Regions in Brussels [Harvie 1994: 54]. The realization of the principle of subsidiarity turned to be the focal point of the demands of European regions in general and the Italian regions in particular [Ciuffoletti 1994: 181-183].

\section{The End of the First Republic}

While the 1960s and 1970s were characterized by terrorism and political violence in Italy, the 1980s turned out to be a period of extreme corruption that became institutionalized and systemic [Della Porta 1997: 35]. Italy only began to seriously tackle corruption in 1992, which was the year that marked the beginning of the end of the First Republic. The decisive crisis of the Italian multiparty system that occurred in the early 1990s was caused not only by inter-party clashes, but also by such external factors as the collapse of so-called "real socialism" in Eastern Europe [Tullio-Altan 2000: 248-249].

Italy was the only western country in which drastic changes to the party system and political regime coincided with the democratization of Eastern Europe. Consequently, Italian "blocked democracy" suddenly began to move: the elimination of the confrontation between the West and the East, economic crisis in the country, the declining influence of two main Italian political subcultures - Catholic and Communist - and political scandals which revealed enormous elite corruption, all led to a profound legitimacy crisis of the leading Italian 
political parties [De Paulis-Dalambert 2006: 7-8]. ${ }^{11}$ Italy witnessed the emergence of new political forces that had hardly been seen previously or had not existed at all: Forza Italia, the Northern League, and the MSINational Alliance [Lotti 1997: 173-174].

The crisis of the First Republic's political system convinced its elites that it was necessary to change the rules of the electoral game. This change would make possible the regrouping of traditional political parties and would open up an opportunity for the new political forces of the post-industrial society to achieve a more adequate representation of their interests in the structures of power. After receiving the approval of the majority of Italians to reform the electoral system in a referendum held on 18 April 1993, the Italian Parliament elaborated and adopted a new electoral law. In this referendum, $90 \%$ of the $77 \%$ of Italian voters who took part in it approved of the recommended changes. According to them, the principle electoral district for the Senate should be the region, and its 315 seats should be distributed proportionately. Only two regions-Valle d'Aosta and Molise - were exempted from the proportional distribution of seats by electing one and two senators. The system of proportional representation, which guided the elections to the Lower House of the Italian Parliament, gave way to the plurality voting system. Six hundred and thirty seats in the Chamber of Deputies had be distributed between the regions according to the number of their inhabitants, with three-quarters of the deputies to be elected in the single-member districts and only one-quarter on the basis of proportional representation [Lotti 1997: 172].

As a result of these changes, the Italian electoral system was radically overhauled. The elections of 27 March 1994 that were held on the basis of the new electoral law led to highly unexpected political outcomes that severely undermined the existing political system of the First Republic. The parties of the Left (including the left-wing faction of Christian Democrats) who had been the prime forces behind the electoral reform, were quite sure of their dominance over the traditional as well as the new right-wing parties. But it was the latter that won the elections by a landslide. Contrary to the fears of the Northern League's leaders, it was rewarded by the new electoral system: for the Chamber of Deputies they polled 3,237,000 votes, while the National Alliance (AN) got 5,202,000 and Forza Italia received 8,119,000. In total, the League gained 117 seats, compared with 109 for the AN and 99 for Forza Italia [Tambini 2001: 64].

The new Italian Right's victories were caused primarily by their discriminatory strategy in the formation of electoral coalitions. Because it was entirely impossible for the League and the National Alliance to find any common denominators in their platforms beyond their hostility towards non-European immigrants, ${ }^{12}$ Forza Italia forged two territorially distinct political coalitions: in the North it allied with the League, while in the South it joined forces with the National Alliance [Lotti 1997: 73-74]. The alliance of the League with Forza Italia in the North was based on their similar stances on the causes of inefficiency in public institutions and their support of privatization as the best remedy to overcome this deficiency [Ciuffoletti 1994: 77].

By destroying the old party system these developments signified the transformation of the First Italian Republic into the Second Republic. The elections showed that the aggregation of political and social interests

11 "Ideological bipolarity, which juxtaposed two main political cultures (the 'white' culture of the Christian democracy and the 'red' culture of the Communists) lost its meaning after the demise of the Communism; besides that the financial crisis of the state and the welfare system drastically reduced the redistributive capacities of the social institutions, and subsequently the power of political parties, which secured control" [Briquet 1997: 51].

“Whereas the League stands for federalism, the AN calls for 'presidentialism' - a more powerful central executive. The AN's strongest base of support is among relatively poor voters in Italy's south — the part of the country from which the League wishes to divorce itself" [Rosenthal 1996: 163]. To pay tribute to Bossi's political flexibility it should be noted that the possibility of forming a coalition with Berlusconi's party pressed the League to modify its political slogans. The previous separatist model was transformed into a more moderate one. It rejected the separation of the North and envisaged the creation of an Italian federation that would consist of nine states and twenty regions. If implemented, this concept would lead to the emergence of a renewed centralization of state power in three capitals-Milan, Florence, and Naples - instead of genuine devolution. 
had become much more diverse than they had been during the years of the First Republic. The parties of the Right became the immanent feature of the Italian political landscape. It became obvious that the antifascist ideals lost the importance they had had for the founding fathers of the First Republic. It was a clear signal that the priorities of the Italian political culture had changed throughout the 1980s, which went unnoticed by the leaders of political class who were still engaged in the games of transformismo. The basic elements of the transfer from the First to the Second Italian Republic were the following: starting in 1992, the cleansing of the corrupted traditional Italian political class and the structures it occupied; the referendum of 1993 and the new electoral law; and the results of the 1994 elections that showed that the pendulum of Italian politics had become unblocked at last.

\section{Conclusion}

The crisis of the early 1990s revived and redefined the problems of regionalization. By that time, the inadequacies of the Italian regional system had become obvious to all representatives of the Italian political class; as Putnam, Leonardi, and Nanetti described it: "Public management in many regions has been a Kafkaesque combination of lethargy and chaos" [Putnam, Leonardi, Nanetti 1993: 48]. Regional political institutions were reproducing the failings of their national counterpart that was characterized by rampant clientelism, particularism, and chronic political instability.

The legitimacy crisis of the old Italian political class, which was caused by waves of scandal in the early 1990s, was conducive to the emergence of populist regionalism. New regional movements, mainly in the North where propaganda to separate northern Italy from a corrupted Rome met popular support, widened the spectrum of Italian political parties. Although regionalist movements had always latently existed in Italy, they revealed themselves only during times of crisis caused by the games of either internal or external political actors - often both at the same time. The regional question in Italy was the result of inadequate political, economic, social, and cultural national integration, the inadequate development of democracy, and the inefficient functioning of state institutions.

The end of the Italian political anomaly led to the emergence of territorial identities, which in turn formed the basis of the further expansion of asymmetric stateness. The rise of separatist tendencies in the North made the reform of Italian stateness almost inevitable. By the end of the second millennium, the Italian polity, which had previously always been capable of eradicating socioeconomic and political problems by means of the mechanisms of clientelism and transformismo, reached its limits of expansion. The end of the Italian political anomaly, radically shaken by the scandals of tangentopoli at home as well as the drastic changes experienced beyond its borders, and the deepening of European integration promised to put an end to the uni-dimensional forced asymmetry of Italy's ordinary and special regions by including them in the multidimensional European regional framework.

The regionalization of Italy, which for more than a century had been the function of national elites' interests and thus - by default - a top-down process, was steadily being replaced by a bottom-up process while being promoted by the regional actors who were more and more inclined to proclaim federalist ideas [Desideri, Santantonio 1997: 99]. The national stratum of the Italian political class responded to the pressure of its meso-level counterparts by incrementally broadening regional competencies without the comprehensive constitutional reform of Italian stateness; this gradually evolved into a system characterized as "cooperative regionalism" [Palermo, Wilson 2014: 512].

From the beginning of the $1990 \mathrm{~s}$, the regions had found themselves in a very different environment caused by tangentopoli which on the surface had appeared to be a purely political scandal but actually shattered many other dimensions of the Italian economy and society and launched the ongoing transformation of the Italian 
polity: "From 1992 onwards, many regions found themselves politically decapitated due to the number of elected members incriminated" [Dente 1997: 182]. Consequently, and as had happened many times before in the course of modern Italian history, the regional question was again placed at the very center of political discourse.

However, in comparison to other major transformations of the Italian polity, this regional discourse had two major differences. First of all was the actual intensity of the discourse and the variety of its participants (including political parties, the media, scholars, unions, and even the Catholic Church) - all of whom suggested different plans for Italian devolution. The second distinguishing feature was the active participation of the regions; most interestingly, it was not the special regions but the ordinary ones that were its most energetic protagonists. The ordinary regions - especially the regions of the North — demanded the widening of their competencies that would promote them to the level of the special regions. Regionalism became a new dimension of Italian politics in which the horizontal links of the actors dominate traditional clientelist vertical links, thereby representing a change that gave a serious impetus to the socioeconomic and political modernization of this territorial level of government.

The regions of the Italian North-East that have in the last thirty years developed export-oriented industries based on small and medium-sized enterprises illustrate the inclusion of European regions into the process of 'glocalization' in general and into the process of European integration in particular [Bagnasco, Oberti 1998: 155-156]. The case of the Italian North-East is a typical example of how unbalanced economic growth is often followed by an increase in political demands for greater political autonomy [Rosenthal 1996: 162]. In Italy, international competition played the role of external catalyst, which aggravated regional competition at the domestic level, and thus intensified the criticism of Rome, whose dysfunctional (at least according to the leaders of those regions) policies hindered regional socioeconomic development. Among these claims, the demands for tax autonomy were the most persistent [Cook, Morgan 1994: 105].

These developments demonstrated the diminishing capacity of Italian national integration and even more than the activities of the Northern League pointed to the necessity of another reform of Italian stateness. This was recognized by many Italians throughout the country, even though these preferences were spread highly unevenly among the regions. While in 1994 more than half of Italians in the northern regions expressed their sympathies for the federalization of the country, only about a third of the southerners had the same preferences. Consequently, about a third of Italians in the North had negative opinions on federalization, while in the South this amounted to more than half. The results of these polls demonstrated the preference of the Southerners for the traditional policies of redistribution and reflected their fear that broader regionalization might lead to even larger disparities. The people of the Mezzogiorno still regarded the strong centralized state as the best guarantor of economic support and as protection against further imbalances [Gold 2003: 67]. Social guarantees, as well as developmental policies, continue to be dependent in southern Italy upon transfers and the structural interventions of the state. That is why the orientation towards the national level of political decision-making was much stronger there than it was in the North. The existing cultural and sociopolitical peculiarities of the South were reinforced by these policies even further which had a negative impact on the politics in these regions because the regional dimension there was perceived as less relevant than in the North. The inability of the southern regions to fill the areas of authority assigned to them by the constitution made it easy for the central government to intervene frequently in their affairs, thus competing with or substituting regional institutions.

The very success of a few northern regions clearly demonstrated the limits of Italian devolution, which was put in place by the constitutional framework of the First Republic. The 2001 constitutional reform substantially changed the relations between Rome and the regional governments and affected the congruence of ordinary and special status regions. While their asymmetry was constitutionally confirmed, the ordinary regions 
were given the right to request the transfer of additional competencies by acts of the Parliament. Article 117 now lists all the legislative powers of the central state and leaves all other policy fields to the regions. The latter now has full control over healthcare and gained an enhanced role in economic development, professional training, agriculture, and the environment [Palermo, Wilson 2014: 514].

The most prosperous Italian regions saw the possibility of continuing their successful political and economic developments not only through the transformation of Italy into a fully-fledged federal state but also through a broadening of the regions' participation in the "Europe of the regions," i.e., the inclusion of Italian regions into the growing framework of European meso-level governments. After the first wave of European regionalization in the 1970s, the regions of the EU emerged in the early 1990s as a potential area for economic and political modernization. The parallel developments of European supra-national structures lead to the erosion of European nation states, although this process cannot be regarded as a mere zero-sum game. The process of European unification is strengthening the role of the regions as an appropriate framework for political action and is inducing concessions from the nation-states. The EU support for the process that assigns more democratic rights and functions to sub-national bodies opens up new possibilities for the political activity of the regions. The current crisis of the Union may cause its supra-national structures to turn to its sub-national and regional nationalisms for support in its attempt to curb the state-wide nationalisms emerging in Europe.

\section{References}

Bagnasco A., Oberti M. (1998) Italy: 'Le Trompe-l'œil' of Regions. Regions in Europe, London: Routledge, pp. $150-165$.

Baldi B. (2006) Regioni e federalismo. L'Italia el'Europa [Regions and Federalism. Italy and Europe], Bologna: CLUEB (in Italian).

Baldi B., Baldini G. (2008) Italia. Da stato unitario a stato federale. Territorializzazione della politica, devoluzione e adattamento instituzionale [From Unitary State to Federal State. Territorialization of Politics, Devolution and Institutional Adaptation], Bologna: Società editirice il Mulino, pp. 69-112 (in Italian).

Baudner J., Bull M. J. (2013) The Europeanisation of National Institutions Reassessed: A Comparison of Regional Policies in Germany and Italy. Comparative European Politics, vol. 11, no 2, pp. 201-221.

Bencardino F. (1997) Federalismo e regionalismo in Italia: prospettive di riasetto politico amministrativo [Federalism and Regionalism in Italy, the Prospects of a Political-Administrative Reorganization], Napoli: Edizioni scientifiche italiane (in Italian).

Bifulco R. (2004) Le regioni [The Regions], Bologna: Società editirice il Mulino (in Italian).

Bogdanor V. (1979) Devolution, Oxford: Oxford University Press.

Briquet J.-L. (1997) Fine dell'anomalia italiana? [The End of Italian Anomaly?] Stanchi di miracoli: il sistema politico italiano in cerca di normalità [Tired of Miracles: The Italian Political System in Search of Normality], Milano: Guerini e associate, pp. 49-59 (in Italian).

Cassese S., Torchia L. (1993) The Meso Level in Italy. The Rise of Meso-Government in Europe, London: Sage, pp. 91-116. 
Chiaramonte U. (1998) Il dibattito sulle autonomie nella storia d'Italia, 1796-1996: uniti, federalismo, regionalismo, decentramento [The Debate on Autonomy in the History of Italy, 1796-1996; Unity, Federalism, Regionalism, Decentralization], Milano: F. Angeli Storia (in Italian).

Ciuffoletti Z. (1994) Federalismo e regionalismo: da Cattaneo alla Lega [Federalism and Regionalism: from Cattaneo to the League], Roma: Laterza (in Italian).

Condorelli L. (1986) The Powers of Regions in the Field of External Relations: The Italian Experience. Regionalism in European Politics, London: PSI, pp. 144-154.

Cook P., Morgan K. (1994) Growth Regions under Duress: Renewal Strategies in Baden-Würtemberg and Emilia-Romagana. Globalization, Institutions, and Regional Development in Europe, Oxford: Oxford University Press, pp. 91-117.

Della Porta D. (1997) The Vicious Circle of Corruption in Italy. Democracy and Corruption in Europe, London: Pinter, pp. 35-49.

Dente B. (1997) Sub-National Governments in the Long Italian Transition. West European Politics, vol. 20, no 1, pp. 176-193.

Desideri C., Santantonio V. (1997) Building a Third Level in Europe: Prospects and Difficulties in Italy. The Regional Dimension of the European Union. Towards a Third Level in Europe? London: Frank Cass, pp. 96-116.

De Paulis-Dalambert M. P. (2006) Avant-propos [Introduction]. L'Italie entre XXe et XXIe siècle: la transition infinie [Italy between the XX and XXI Centuries: the Infinite Transition], Paris: Presses Sorbonne Nouvelle, pp. 7-11 (in French).

Di Palma G. (1982) Italy: Is There a Legacy and Is It Fascist? From Dictatorship to Democracy: Coping with the Legacies of Authoritarianism and Totalitarianism, London: Greenwood Press, pp. 107-134.

Ferrera M., Gualmini E. (2000) Reforms by Consensus: The Welfare State in Italian Transition. Recasting European Welfare States, London: Frank Cass, pp. 187-208.

Finley M. I., Mack Smith D., Duggan C. (1987) A History of Sicily, New York: Elisabeth Sifton BooksViking.

Galli G, Prandi A. (1970) Patterns of Political Participation in Italy, New Haven: Yale University Press.

Giordano B. (2000) Italian Regionalism or 'Padanian' Nationalism - The Political Project of the Lega Nord in Italian Politics. Political Geography, vol. 19, pp. 445-471.

Gold T. W. (2003) The Lega Nord and Contemporary Politics in Italy, New York: Palgrave Macmillan.

Grote J. R. (1996) Cohesion in Italy: A View on Non-Economic Disparities. Cohesion Policy and European Integration: Building Multi-Level Governance, Oxford: Oxford University Press, pp. 256-293.

Gualini E. (2004) Multi-Level Governance and Institutional Change: The Europeanization of Regional Policy in Italy, Burlington, VT: Ashgate. 
Harvie C. (1994) The Rise of Regional Europe, London: Routledge.

Hearder H. (1983) Italy in the Age of the Risorgimento. 1790-1870, New York: Longman.

Hine D. (1993) Governing Italy. The Politics of Bargained Pluralism, Oxford: Clarendon Press.

Hooghe L., Marks G. (2008) A Postfunctionalist Theory of European Integration: From Permissive Consensus to Constraining Dissensus. British Journal of Political Science, vol. 39, pp. 1-23.

Hopkin J., Mastropaolo A. (2001) From Patronage to Clientelism: Comparing the Italian and Spanish Experiences. Clientelism, Interests, and Democratic Representation: The European Experience in Historical and Comparative Perspective, Cambridge: Cambridge University Press, pp. 152-171.

Keating M. (1988) State and Regional Nationalism: Territorial Politics and the European State, London: Harvester \& Wheatsheaf.

Keating M. (1996) Nations Against the State. The New Politics of Nationalism in Quebec, Catalonia and Scotland, New York: St. Martin Press, Inc.

Koff Z., Koff S. P. (2000) Italy. From the First to the Second Republic, London: Routledge.

Kogan N. (1983) A Political History of Italy: The Postwar Years, New York: Praeger Publishers.

Lepre A. (2004) Storia della prima Repubblica. L'Italia dal 1943 al 2003 [History of the First Republic. Italy from 1943 to 2003], Bologna: Società editrice il Mulino (in Italian).

Linz J. J., Stepan A. (1996) Problems of Democratic Transition and Consolidation. Southern Europe, South America, and Post-Communist Europe, Baltimore: The John Hopkins University Press.

Lotti L. (1997) I partiti della Repubblica: La politica in Italia dal 1946 al 1997 [The Parties of the Republic. The Politics in Italy from 1946 to1997], Firenze: Felice Le Monnier (in Italian).

Mack Smith D. (1974) Regionalism. Modern Italy: A Topical History Since 1861, New York: New York University Press, pp. 125-146.

Mack Smith D. (1997) Modern Italy. A Political History. Ann Arbor: The University of Michigan Press.

Marletti C. (1997) Perché non siamo un paese "normale" [Because We are not a "Normal" Country] Stanchi di miracoli: il sistema politico italiano in cerca di normalità [Tired of Miracles: The Italian Political System in Search of Normality], Milano: Guerini e associate, pp. 61-72 (in Italian).

Mazzoleni M. (2009) The Italian Regionalisation: A Story of Partisan Logics. Modern Italy, vol. 14, no 2, pp. 135-150.

Morlino L. (2013) The Impossible Transition and the Unstable New Mix: Italy 1992-2012. Comparative European Politics, vol. 11, no 3, pp. 337-359.

Newton M. T., Donaghy P. J. (1997) Institutions of Modern Spain. A Political and Economic Guide, Cambridge: Cambridge University Press. 
Ocaña L. M. (1989) El Estado de las Autonomías territoriales. Aspectos institutionales [The State of Territorial Autonomies. Institutional Aspects]. Pasado, presente y futuro de las Communidades Autónomas [Past, Present and Future of Autonomous Communities], Madrid: Instituto de Estudios Económicos, pp. 71-163 (in Spanish).

Palermo F., Wilson A. (2014) The Multi-level Dynamics of State Decentralization in Italy. Comparative European Politics, vol. 12, no 4/5, pp. 510-530.

Perdomo J. V. (2001) La región en la organización territorial del estado [The Region in the Territorial Organization of State], Bogotá: Centro Editorial Universidad del Rosario (in Spanish).

Pizzetti F. (1996) Federalismo, regionalismo e riforma dello Stato [Federalism, Regionalism and the Reform of the State], Torino: Bollati Boringhieri (in Italian).

Putnam R., Leonardi R., Nanetti R. Y. (1993) Making Democracy Work: Civic Traditions in Modern Italy, Princeton: Princeton University Press.

Rosenthal L. (1996) Dateline Rome: The New Face of Western Democracy. Foreign Policy, vol. 104, no 4, pp. 154-168.

Tambini D. (2001) Nationalism in Italian Politics: The Stories of the Northern League, 1980-2000, London: Routledge.

Tarrow S. G. (1977) Between Center and Periphery. Grassroots Politicians in Italy and France, New Haven and London: Yale University Press.

Trigilia C. (1993) Governare la diversità: le condizioni non economiche dello sviluppo [Governing the Diversity: Non-economic Conditions of Development]. Regionalismo e Mezzogiorno [Regionalism and Southern Italy]: GENS, pp. 113-131 (in Italian).

Tullio-Altan C. (2000) La nostra Italia, clientelismo, transformismo e ribellismo dall'Unità al 2000 [Our Italy, Clientelism, Transformism and Rebellion from Unification to 2000], Milano: Edizioni Giuridiche Economiche Aziendali (in Italian).

Vannucci A. (1997) Politicians and Godfathers: Mafia and Political Corruption in Italy. Democracy and Corruption in Europe, London: Pinter, pp. 50-64.

Ventresca R. (2004) From Fascism to Democracy: Culture and Politics in the Italian Election of 1948, Toronto: University of Toronto Press.

Warner C. M. (2001) Mass Parties and Clientelism: France and Italy. Clientelism, Interests, and Democratic Representation. The European Experience in Historical and Comparative Perspective, Cambridge: Cambridge University Press, pp. 122-151.

Watson M. M. (1970) Regional Development Policy and Administration in Italy, London: Longman.

Weibel E. (1971) La création des régiones autonomes à statut special en Italie [The Creation of Autonomous Regions of Special Statute in Italy], Paris: Librairie DROZ (in French). 
Wilson A. (2015) Direct Election of Regional Presidents and Party Change in Italy. Modern Italy, vol. 20, no 2, pp. 185-198.

Citation: Zhdanov V. (2017) Post-Authoritarian Devolution: The Case of the First Italian Republic. Journal of Economic Sociology = Ekonomicheskaya sotsiologiya, vol. 18, no 1, pp. 110-131. Available at: https://ecsoc. hse.ru/2017-18-1.html (in English). 
Экономическая

социология

T. 18. № 1.

Январь 2017

Электронный журнал www.ecsoc.msses.ru

www.ecsoc.hse.ru

ISSN 1726-3247

\section{Адрес редакции}

101000, Россия,

г. Москва,

ул. Мясницкая,

д. 20, комн. 406

тел.: (495) 628-48-86

email: ecsoc@hse.ru

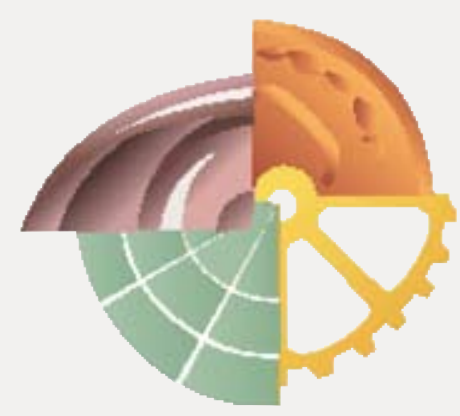

Journal of

Economic Sociology

Vol. 18. No 1.

January 2017

Electronic journal

www.ecsoc.msses.ru

www.ecsoc.hse.ru

ISSN 1726-3247

\section{Contacts}

20 Myasnitskaya street, room 406

101000 Moscow,

Russian Federation phone: +7 (495) 628-48-86

email: ecsoc@hse.ru

\section{Доступ к журналу}

- Доступ ко всем номерам журнала - постоянный, свободный и бесплатный.

- Каждый номер содержится в едином файле (10-12 п. л. в PDF).

- Если хотите, чтобы Вас оповещали о выходе очередного номера, пожалуйста, заполните форму подписки: https:/www.hse.ru/expresspolls/ poll/23725626.html

\section{Open Access Policy}

- All issues of the Journal of Economic Sociology are always open and free access.

- Each entire issue is downloadable as a single PDF file.

- If you wish to receive notification when new issues are published, please fill out the following form: https://www.hse.ru/expresspolls/poll/23725626.html 